NUREG/CR-3510

PNL-4798

\title{
Field Testing of Fugitive Dust Control Techniques at a Uranium Mill Tailings Pile - 1982 Field Test, Gas Hills, Wyoming
}

Prepared by M. R. Elmore, J. N. Hartley

Pacific Northwest Laboratory

Operated by

Battelle Memorial Institute

Prepared for

U.S. Nuclear Regulatory

Commission 


\section{NOTICE}

This report was prepared as an account of work sponsored by an agency of the United States Government. Neither the United States Government nor any agency thereof, or any of their employees, makes any warranty, expressed or implied, or assumes any legal liability of responsibility for any third party's use, or the results of such use, of any information, apparatus, product or process disclosed in this report, or represents that its use by such third party would not infringe privately owned rights.

\section{Availability of Reference Materiais Cited in NRC Publications}

Mort documents cited in NRC publications will be available from one of the following sources:

1. The NRC Public Document Room, 1717 H Street, N.W. Washington, DC 20555

2. The NRC/GPO Sales Program, U.S. Nuclear Regulatory Commission, Washington, DC 20555

3. The National Technical Information Service, Springfield, VA 22161

Although the listing that follows represents the majority of clocuments cited in NAC publications, it is not intended to be exhaustive.

Referenced documents available for inspection and copying for a fee from the NAC Public Document Room include NRC correspondence and iriternal NRC memoranda; NRC Office of Inspection and Enforcement bulletins, circulars, information notices, inspection and investigation notices; Licensee Event Reports; vendor reports and correspondence; Commission papers; and applicant and licensee documents and correspondence.

The following documents in the NUREG series are available for purchase from the NRC/GPO Sales Program: formal NRC staff and contractor reports, NAC-sponsored conference proceedings, and NRC booklets and brochures. Also available are Regulatory Guides, NRC regulations in the Code of Federal Regulations, and Nuclear Regulatory Commission /ssuances.

Documents available from the National Technical Information Service include NUREG series reports and technical reports prepared by other federal agencies and reports prepared by the Atomic Energy Commission, forerunner agency to the Nuclear Regulatory Commission.

Documents available from public and special technical libraries include all open literature iterns, such as books, journal and periodical articles, and transactions. Federal Register notices, federai and state legislation, and congressional reports can usually be obtained from these libraries.

Documents such as theses, dissertations, foreign reports and translations, and non-NRC conference proceedings are available for purchase from the organization sponsoring the publication cited.

Single copies of NRC draft reports are available free upon written request to the Division of Technical Information and Document Control, U.S. Nuclear Regulatory Commission, Washington, DC 20555.

Copies of industry codes and standards used in a substantive manner in the NRC regulatory process are maintained at the NAC Library, 7920 Norfolk Avenue, Bethesda, Maryland, and are available there for reference use by the public. Codes and standards are usually copyrighted and may be purchased from the originating organization or, if they are American National Standards, from the American National Standards Institute. 1430 Broadway, New York, NY 10018. 
NUREG/CR-3510

PNL-4798

RU

\section{Field Testing of Fugitive Dust Control Techniques at a Uranium Mill Tailings Pile - 1982 Field Test, Gas Hills, Wyoming}

Manuscript Completed: September 1983

Date Published: December 1983

Prepared by

M. R. Elmore, J. N. Hartley

Pacific Northwest Laboratory

Richland, WA 99352

\section{Prepared for}

Division of Health, Siting and Waste Management

Office of Nuclear Regulatory Research

U.S. Nuclear Regulatory Commission

Washington, D.C. 20555

NRC FIN B2370 


\section{ACKNOWLEDGMENTS}

The authors wish to thank the management and personnel of the Federal American Partners Mill for their help and cooperation in the research work. In addition, the authors wish to thank $W . F$. Riemath and $C$. T. Li of Pacific Northwest Laboratory for their assistance during the field test. 



\section{ABSTRACT}

A field test was conducted on a uranium tailings pile to evaluate the effectiveness of 15 chemical stabilizers for control of fugitive dust from uranium mill tailings. A tailings pile at the Federal American Partners (FAP) Uranium Mill, Gas Hills, Hyoming, was used for the field test. Preliminary laboratory tests using a wind tunnel were conducted to select the more promising stabilizers for field testing. Fourteen of the chemical stabilizers were applied with a field spray system pulled behind a tractor; one--Hydro Mulch-was applied with a hydroseeder. A portable weather station and data logger were installed to record the weather conditions at the test site. After 1 year of monitoring (including three site visits), all of the stabilizers have degraded to some degree; but those applied at the manufacturers' recommended rate are still somewhat effective in reducing fugitive emissions. The following synthetic polymer emulsions appear to be the more effective stabilizers: HaT1pol 40-133 from Reichold Chemicals, SP-400 from Johnson and March Corporation, and $\mathrm{CPB}-12$ from Wen Don Corporation. Installed costs for the test plots ranged from $\$ 8,400$ to $\$ 11,300 /$ ha; this range results from differences in stabilizer costs. Large-scale stabilization costs of the test materials are expected to range from $\$ 680$ to $\$ 3600 /$ ha based on FAP experience. Evaluation of the chemical stabilizers will continue for approximately 1 year. 

SUMMARY

Pacific Northwest Laboratory (PNL), under contract to the U.S. Nuclear Regulatory Commission, is investigating technologies to reduce fugitive dust emissions from uranium mill tailings. These technologies include the use of physical and chemical stabilizers. In August 1982, a field test was initiated at the Federal American Partners (FAP) (a) Uranium Mi11, Gas Hills, Wyoming. The objective of the field test was to evaluate and compare the effectiveness of selected stabilizers on a 0.57 -ha $(1.42-$ acre) test site divided into 30 individual $(6 \times 20 \mathrm{~m})$ test plots. Results from the field test have demonstrated that the stabilizers applied at the manufacturers' recommended application rate are somewhat effective in reducing fugitive dust emissions on a short-term basis ( -1 year). This report details the preliminary activities, the 1982 field test, and the subsequent monitoring activities; the results are summarized below.

\section{PRELIMINARY ACTIVITIES}

- Preliminary laboratory studies (including wind tunnet tests) were used to test 34 chemical stabilizers under a variety of conditions (wind speed, temperature cycling, wet/dry cycling, application rate, concentration, etc.) using simulated tailings; 15 chemical stabilizers were selected for the field test.

- Eight uranium mills were visited to select a field test site. The FAP site was chosen because of its location, tailings condition, and availability of space and equipment.

- A portable field spray system consisting of a 6-m spray boom with 12 nozzles and a gas-powered pump that could be pulled behind a tractor was selected for the field test.

\section{FIELD TEST ACTIVITIES}

The field test activities consisted of site preparation and characterization, stabilizer application, and field test monitoring.

Site Preparation and Characterization

- The 0.57-ha test site is located on the southwest side of the No. 2 tailings pile (primarily beach sands). The top $-5 \mathrm{~cm}$ of the tailings were removed because the site had been previously stabilized

(a) FAP recently changed its name to American Nuclear Corporation-Gas Hills Project. 
with a lignin sulfonate stabilizer (Orzan $C$ ). The surface was leveled, and the 30 test plots were surveyed.

- Each test plot was sampled at five locations to a depth of $\sim 5 \mathrm{~cm}$ just prior to stabilizer application. Moisture and particle size analyses were performed. The moisture content of the tailings ranged from 1.6 to 8.2 wt\% (dry basis); the higher moisture content resulted from rain prior to stabilizer application.

- Screen analysis showed that the particle size distribution of each test plot was nearly the same, indicating that the surface tailings of the test area were uniform.

- The amount of water-soluble salts present in the tailings test plots was determined. In some cases these salts might be detrimental to the longevity of the stabilizers; but, due to the natural crusting that occurs when these salts dry, they may activaliy decrease the amount of erosion. This chemical analysis further verified the uniformity of the tailings in the test plots.

Stabilizer Application

- Fifteen chemical stabilizers were applied at two selected concentrations: the manufacturers' recomended application and one-half that application.

- Fourteen of the stabilizers were applied with the portable field spray system previously described. Minor problems were noted in the application of Soil Gard, which coagulated in the sprayer pump tank. Hydro Mulch with an added tackifier was applied to two test plots using a hydroseeder.

- Selected areas on each test plot were identified, marked, and photographed to monitor changes with time.

- The installed costs of the chemical stabilizers were determined for each test plot; they ranged from $\$ 8,400$ to $\$ 11,300 /$ ha. Material costs ranged from $\$ 360$ to $\$ 3,280 /$ ha. Large-scale stabilization costs for the test materials are expected to be considerably lower, ranging from $\$ 680$ to $\$ 3600 /$ ha based on FAP experience.

Field Test Monitoring

- After 1 year of monitoring (including three site visits), the stabilizers have degraded to some degree; but those applied at the manufacturers' recomended concentration still appear to be somewhat effective in reducing fugitive tailings emissions. The following synthetic polymer emulsions were found to be the more effective 
chemical stabilizers: Walipol 40-133 from Reichold Chemicals, $\mathrm{SP}-400$ from Johnson and March Corporation, and $\mathrm{CPB}-12$ from Wen Don Corporation.

- The weather conditions at the test site were monitored by a portable weather station and data logger. Wind speed and direction, soil and air temperature, humidity, solar radiation, and rainfall were recorded. These data are being used to help evaluate the effectiveness of the stabilizers. 



\section{CONTENTS}

ACKNOWLEDGMENTS. ...................................

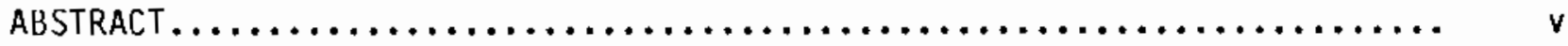

SUMMARY......................................... vii

INTRODUCTION......................................... 1

CONCLUSIONS AND RECOMMENDATIONS......................... 3

PREL IMINARY ACTIVITIES $\ldots \ldots \ldots \ldots \ldots \ldots \ldots \ldots \ldots \ldots \ldots \ldots \ldots \ldots \ldots \ldots \ldots$

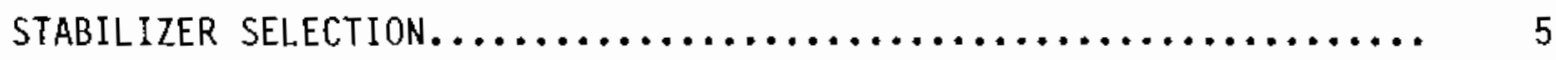

APPLICATION EQUIPMENT REVIEW....................... 11

Stabilizer Constraints.......................... 11

Test Site Constraints............................ 11

Equipment Selection............................. 11

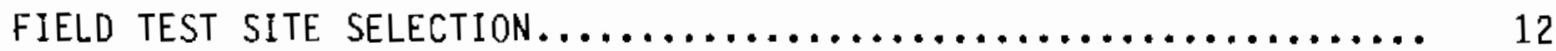

FIELD TEST ACTIVITIES $\ldots \ldots \ldots \ldots \ldots \ldots \ldots \ldots \ldots \ldots \ldots \ldots \ldots \ldots \ldots \ldots \ldots \ldots \ldots$

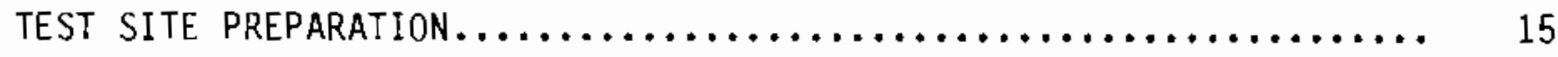

TEST SITE CHARACTERIZATION.......................... 20

TEST SITE INSTRUMENTATION.......................... 23

STABILIZER PREPARATION AND APPLICATION................. 24

SITE PROTECTION................................ 27

FIELD TEST MONITORING................................. 29

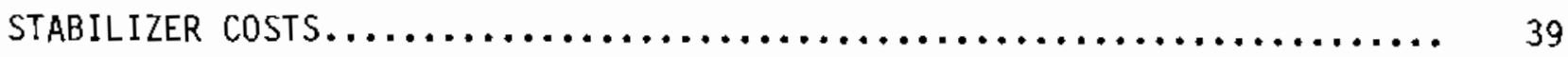

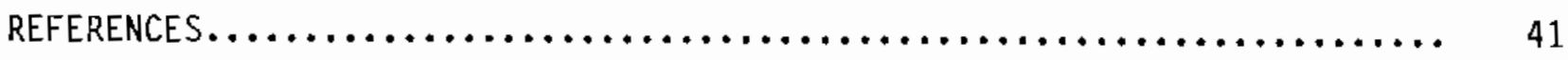

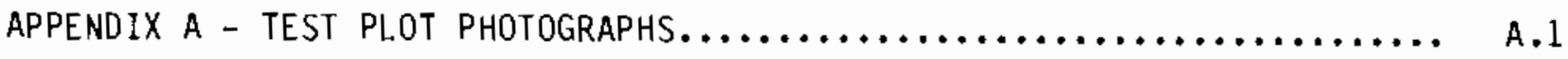

APPENDIX B - FIELD TEST SITE WEATHER DATA................... B. I 


\section{FIGURES}

1 Average Size Distribution of Beach Area Tailings................ 6

2 Spraying Stabilizers on Sand Samples for Wird Tunnel Tests........ 7

3 Wind Tunnel Used in Laboratory Tests........................ 8

4 Sample Being Inserted in Cutout Floor Section of Wind Tunnel...... 9

5 Application of Chemical Stabilizers with a Small Field Sprayer.... 12

6 Federal American Partners Tailings Pile, Ga's Hills, Wyoming....... 15

7 Plan View of Field Test site on FAP Tailings Pile and Surrounding Features...................................... 16

8 Grader Removing Treated Surface Tailings from Test Plot Area...... 17

9 Tractor and Disk Leveling Test Plot Area.................... 18

10 Tractor and Harrow Preparing a Smooth Surface on Test Plot Area................................................. 18

11 Field Test Area Consisting of 30 Test Plots.................... 19

12 Gilson Wet Sieve Shaker Used for Tailings Particie Size

Distribution Studies..................................... 21

13 Weather Station Installed at Field Test..................... 23

14 Application of Hydro Mulch with Hydroseeder.................. 25

15 Test Plot Surface Stabilized with Wallpol 40-133

After 11 Months of Weathering. ............................ 34

16 Test Plot Surface Stabilized with Coherex After

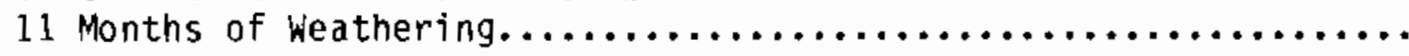

17 Wind Rose Using Wind Velocity and Direction Data Collected

at the FAP Field Test Site from September 1982 through

June 1983

19 Wind Rose Using (Wind Velocity) ${ }^{3}$ and Direction Data

Collectcd at the FAP Field Test Site from September 1982

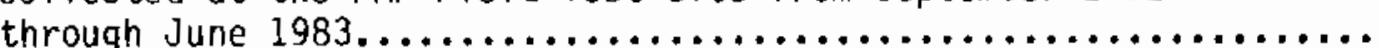

A.1 Test Plot Stabilized with Wallpol $40-133 \ldots \ldots \ldots \ldots \ldots \ldots \ldots \ldots \ldots . . . \ldots$.2 


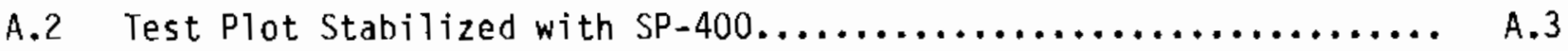

A.3 Test Plot Stabilized with CPB-12.......................... A.4

A.4 Test Plot Stabilized with Sandsti71 II........................ A

A.5 Test Plot Stabilized with Soil Gard......................... A.6

A.6 Test Plot Stabilized with Dust Loc VMX $-50, \ldots \ldots \ldots \ldots \ldots \ldots \ldots \ldots$ A.7

A.7 Test Plot Stabilized with Dust Gard,...................... A.8

A.8 Test Plot Stabilized with Aerospray $-70 \ldots \ldots \ldots \ldots \ldots \ldots \ldots \ldots \ldots$ A.9

A.9 Test Plot Stabilized with Orzan A............................. A.10

A.10 Test Plot Stabilized with Coherex............................. A.11

A.11 Test Plot Stabilized with Marloc............................. A.12

A.12 Test Plot Stabilized with Hydro Mulch.......................... A.13

A.13 Test Plot Stabilized with Dust Binder C $-266 \ldots \ldots \ldots \ldots \ldots \ldots \ldots \ldots$ A.14

A.14 Test Plot Stabilized with Polyco $2151 \ldots \ldots \ldots \ldots \ldots \ldots \ldots \ldots \ldots \ldots$. A.15

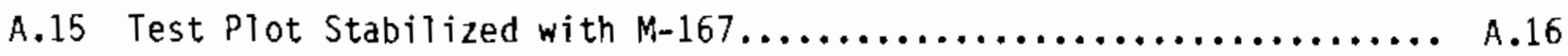




\section{TABLES}

1 Size Distribution of Sand Used as Simulated Tailings for Laboratory Tests..................................... 7

2 Stabilizers Selected for Field Test....................... 10

3 Uranium Mills Considered for Field Test................... 13

4 Surface Moisture for Test Plots Prior to

Stabilizer Application............................... 20

5 Size 0istribution Analysis for Test Plot Surface Samples......... 22

6 Water-Soluble Salt Analyses of Test Plot Surface Samples......... 22

7 Dilution and Application Rates of Field-Tested Stabilizers........ 26

8 Surface Characteristics of Stabilized Test Plots.............. 28

9 Observations of Relative Effectiveness of Chemical Stabilizers..... 30

10 Summary of Weather Data from the Field Tes: Site for September

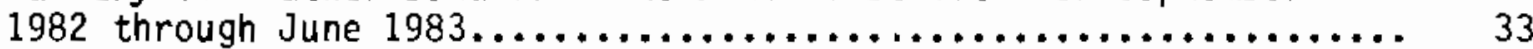

11 Chemical Stabilizers Grouped by Relative Effectiveness

After 1 Year of Heathering............................ 35

12 Application Costs for 1982 Field Test and for a Large-Scale

Stabilization ........................................ 40

B.1 Summary of Precipitation Data at FAP Field Test Site from

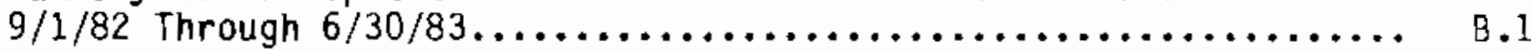

B.2 Federal American Partners Wind Rose Data from

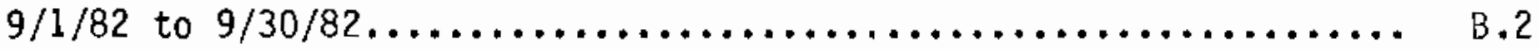

B.3 Federal American Partners Wind Rose Data from

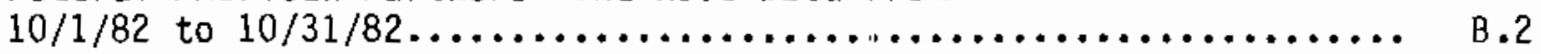

B.4 Federal American Partners Wind Rose Data from

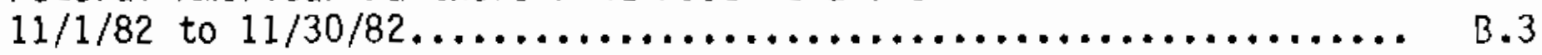

B.5 Federal American Partners Wind Rose Data from

$12 / 1 / 82$ to $12 / 31 / 82$. 
B.6 Federal American Partners Wind Rose Data from

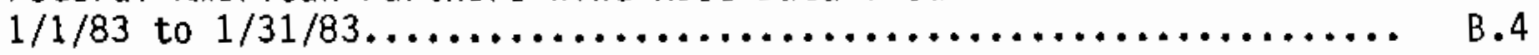

B.7 Federal American Partners Wind Rose Data from

$2 / 1 / 83$ to $2 / 28 / 83 \ldots \ldots \ldots \ldots \ldots \ldots \ldots \ldots \ldots \ldots \ldots \ldots \ldots \ldots \ldots \ldots \ldots \ldots . . \ldots \ldots$

B.8 Federal American Partners Wind Rose Data from

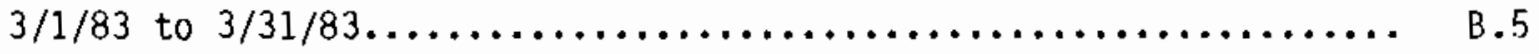

B.9 Federal American Partners Wind Rose Data from

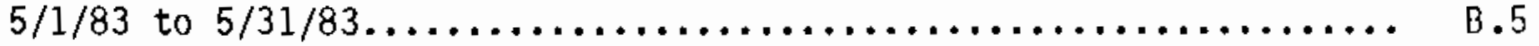

B.10 Federal American Partners Wind Rose Data from

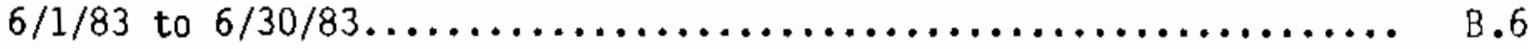





\section{INTRODUCTION}

During the operating life of most uranium mills, process tailings are generally deposited as a slurry in exposed impoundment areas. With time, the water separates from the tailings, leaving a new surface layer of tailings behind the impoundment dam. As the surface of these tailings dries, areas may become subject to wind erosion. If the surface of the tailings is not properly stabilized, wind erosion of the tailings pile will continue throughout the operating phase of the mill and beyond; and wind-blown tailings will impact nearby areas. Permanent reclamation of the tailings pile will ordinarily be performed once the impoundment area is no longer used for tailings disposa1, according to the mill's licensing agreement. However, during the active phase of the disposal area and the interim period before final closure, an effective method of temporary surface stabilization is necessary to prevent wind erosion of the mill tailings.

In response to this need, Pacific Northwest Laboratory (PNL)(a) is investigating the effectiveness, durability, and cost of interim stabilization methods to mitigate the wind erosion of exposed tailings surfaces. The first phase of this U.S. Nuclear Regulatory Commission (NRC)-sponsored study was to identify available stabilization qaterials and techniques that could be applied to uranium mill tailings piles. (1) Currently available stabilizer materials and industrial users of these products (including mining companies and construction industries where fugitive dust is a problem) were reviewed. Soil stabilization methods were grouped into the following categories: chemical, physical, and vegetative stabilization; and 34 chemical stabilizers were identified. All of these materials are applied as liquids to the soil surface and most require dilution with water. Chemical stabilizers appeared to be the most effective for interim stabilization of uranium mill tailings and are generally the easiest to apply to a mill tailings pile.

In the next phase of the study, both laboratory and field studies were conducted to evaluate the effectiveness and durability of selected stabilizer materials. Because of the large number of commercjally available stabilizers, some preliminary laboratory-scale wind tunnel studies were performed to identify the more promising chemical stabilizers and thus limit the number of stabilizers to be field tested. In August 1982, a field test was initiated at a uranium mill tailings pile in wyoming. Weather data were recorded at the test site, and the test plots are being periodically monitored to study the effects of site and environmental conditions on the durability of the stabilizers.

This report summarizes the preliminary laboratory studies, describes the field test activities, and presents some preliminary observations based on short-term (1 year) monitoring of the test site.

(a) Operated for the U.S. Department of Energy (DOE) by Battelle Memorial Institute. 



\section{CONCLUSIONS AND RECOMMENDATIONS}

The following general conclusions can be drawn from the field test and 1 year of monitoring:

- Chemical stabilizers are generally effective in reducing fugitive dust emissions from uranium mill tailings over the short term ( 1 year).

- The use of a specific stabilizer will depend on the requirements at each site and on the availability and cost of the stabilizer.

- The stability of the tailings pile should not be greatly influenced by the presence of the chemical stabilizers; the thin stabilizer crust would generally deteriorate before a new tailings layer would be deposited.

- Site climatic conditions (wind, rain, snow, and freeze/thaw) will strongly influence the durability of the stabilizer.

Based on results of the field test after 1 year of monitoring, the following general recommendations are made:

- An additional 1 to 2 years of field test monitoring are needed to evaluate the overall effectiveness and durability of the stabilizers.

- Some additional field testing should be conducted using new or improved chemical stabilizers that have been identified.

- Wind screen systems may be cost effective for controlling fugitive dust when used separately or in conjunction with chemical stabilizers. A field test to evaluate wind screens should be conducted. 


\section{PRELIMINARY ACTIVITIES}

Prior to the field test, a number of preliminary activities were performed, including: 1) selecting a reasonable number of stabilizers to be tested from those that were commercially available and identifying specific requirements of the selected stabilizers, such as moisture, temperature, and application method; 2) reviewing available application equipment; and 3) selecting an appropriate field test site.

STABILIZER SELECTION

An earlier report on interim stabilization(1) reviewed the state-of-theart technology for fugitive dust control, including available stabilizer materials and methods of application. Based on this review, samples of different chemical stabilizers were obtained from manufacturers. Laboratory wind tunnel tests were conducted at PNL to evaluate these stabilizers. From these tests, the stabilizers were ranked according to their effectiveness for stabilizing the surface of treated sand samples. Details of these laboratory tests will be reported separately. The following discussion includes only the stabilizers that were selected for the 1982 field test.

Operators at several uranium mills indicated that the beach areas of the tailings piles contribute the most to blowing dust. These areas are the first to dry out and have a particle size distribution that is more susceptible to wind erosion than the finer material (slimes) closer to the pond area of the tailings dam. Samples were obtained from the beach areas of different tailings piles, and particle size analyses were performed. The average size distribution of the beach area tailings was determined from these analyses (Figure 1 ). This distribution was used to prepare simulated tailings from nonradioactive, locally available sand (Table 1). The sand was screened to remove material larger than 12 mesh $(>1.70 \mathrm{~mm})$; the bulk of the material was between 20 and 100 mesh $(150$ to $850 \mathrm{~mm})$. The sand was dried overnight at $100^{\circ} \mathrm{C}$ and divided into samples of $\sim 4000 \mathrm{~g}$ each. These sand samples were then placed in $23 \times 30.5-\mathrm{cm}$ pans, leveled, and weighed on an electronic balance.

The chemistry of the tailings (pH and water-soluble salts) was not duplicated in the simulated tailings sand for these initial screening tests. The $\mathrm{pH}$ of the tailings and the water-soluble salts that reprecipitate as the tailings dry varies widely from site to site because differences in the mineralogy of the ores require specific differences in processing. For later laboratory tests, the sand was treated to be chemically similar to the FAP tailings. No discernible effect on the effectiveness of the stabilizers was noted. Although the chemistry of the tailings may not influence the immediate effectiveness of the stabilizers, it may affect the durability of some of the materials with time. 


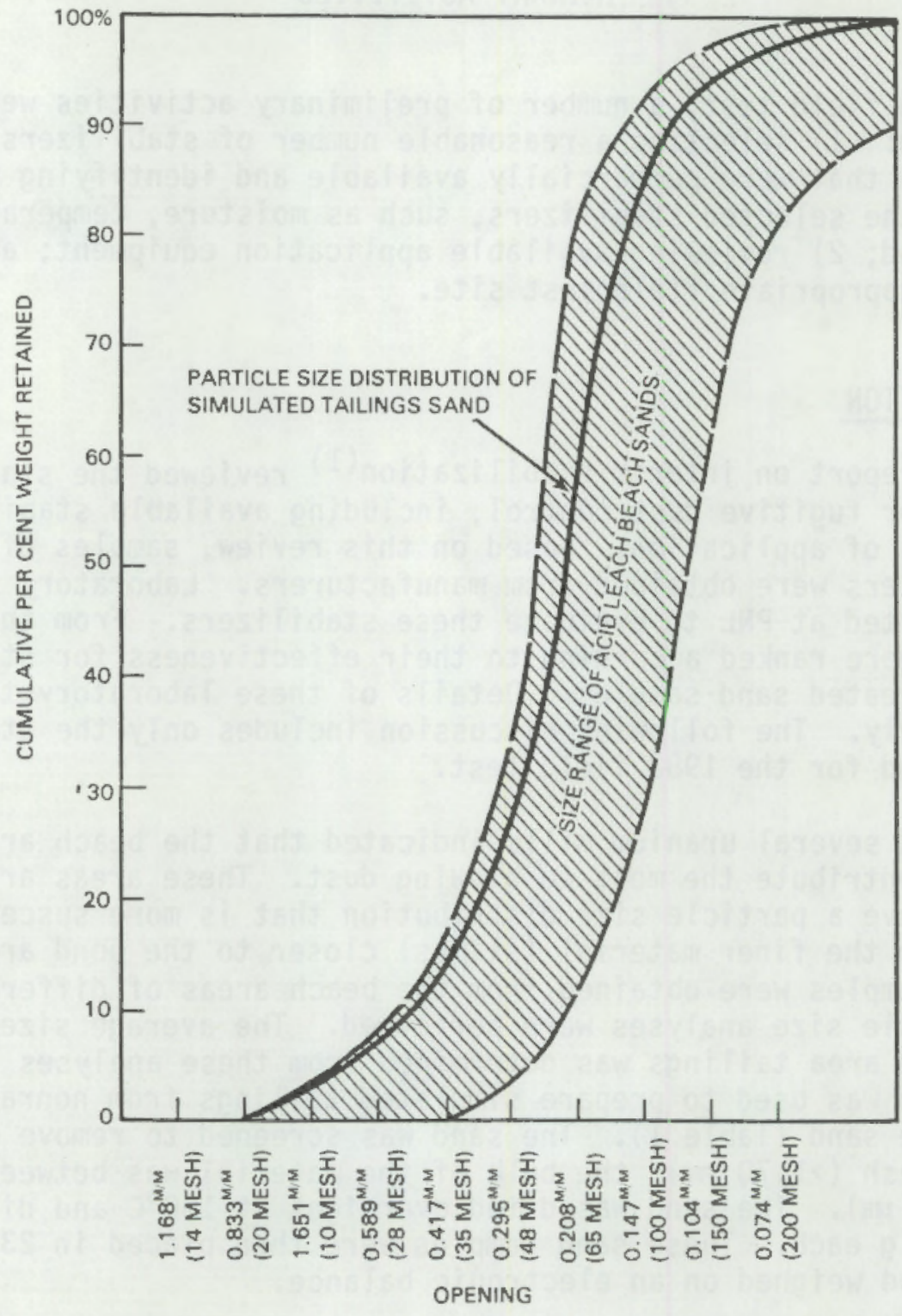

FIGURE 1. Average Size Distribution of Beach Area Tailings

Each of the chemical stabilizers was applied to the simulated tailings according to the manufacturer's recommendations for dilution and application using a small compressed air paint sprayer (Figure 2). The total application of each material was calculated for the surface area of the pan and was determined by the weight gain of the pans as they were sprayed. The treated sand was allowed to cure for a minimum of 3 days at room temperature $\left(-21^{\circ} \mathrm{C}\right)$. 
TABLE 1. Size Distribution of Sand Used as Simulated Tailings for Laboratory Tests

\begin{tabular}{|c|c|c|c|}
\hline Mesh & Opening & $\begin{array}{c}\begin{array}{c}\text { w } \% \\
\text { Retained }\end{array} \\
\end{array}$ & $\begin{array}{c}\text { Cumulative } \\
\text { wt\% } \\
\text { Retained }\end{array}$ \\
\hline 12 & $1.70 \mathrm{~mm}$ & 0 & 0 \\
\hline 16 & $1.18 \mathrm{~mm}$ & 1.18 & 1.18 \\
\hline 20 & $850 \mu \mathrm{m}$ & 2.54 & 3.72 \\
\hline 30 & $600 \mu \mathrm{m}$ & 5.18 & 8.90 \\
\hline 40 & $425 \mu \mathrm{m}$ & 16.23 & 25.13 \\
\hline 50 & $300 \mu \mathrm{m}$ & 41.31 & 66.44 \\
\hline 70 & $212 \mu \mathrm{m}$ & 19.85 & 86.29 \\
\hline 100 & $150 \mu \mathrm{m}$ & 8.83 & 95.12 \\
\hline 140 & $106 \mu \mathrm{m}$ & 2.80 & 97.92 \\
\hline 200 & $75 \mu \mathrm{m}$ & 1.16 & 99.08 \\
\hline 270 & $53 \mu \mathrm{m}$ & 0.33 & 99.41 \\
\hline 325 & $45 \mu \mathrm{m}$ & 0.06 & 99.47 \\
\hline-325 & & 0.53 & 100.00 \\
\hline
\end{tabular}

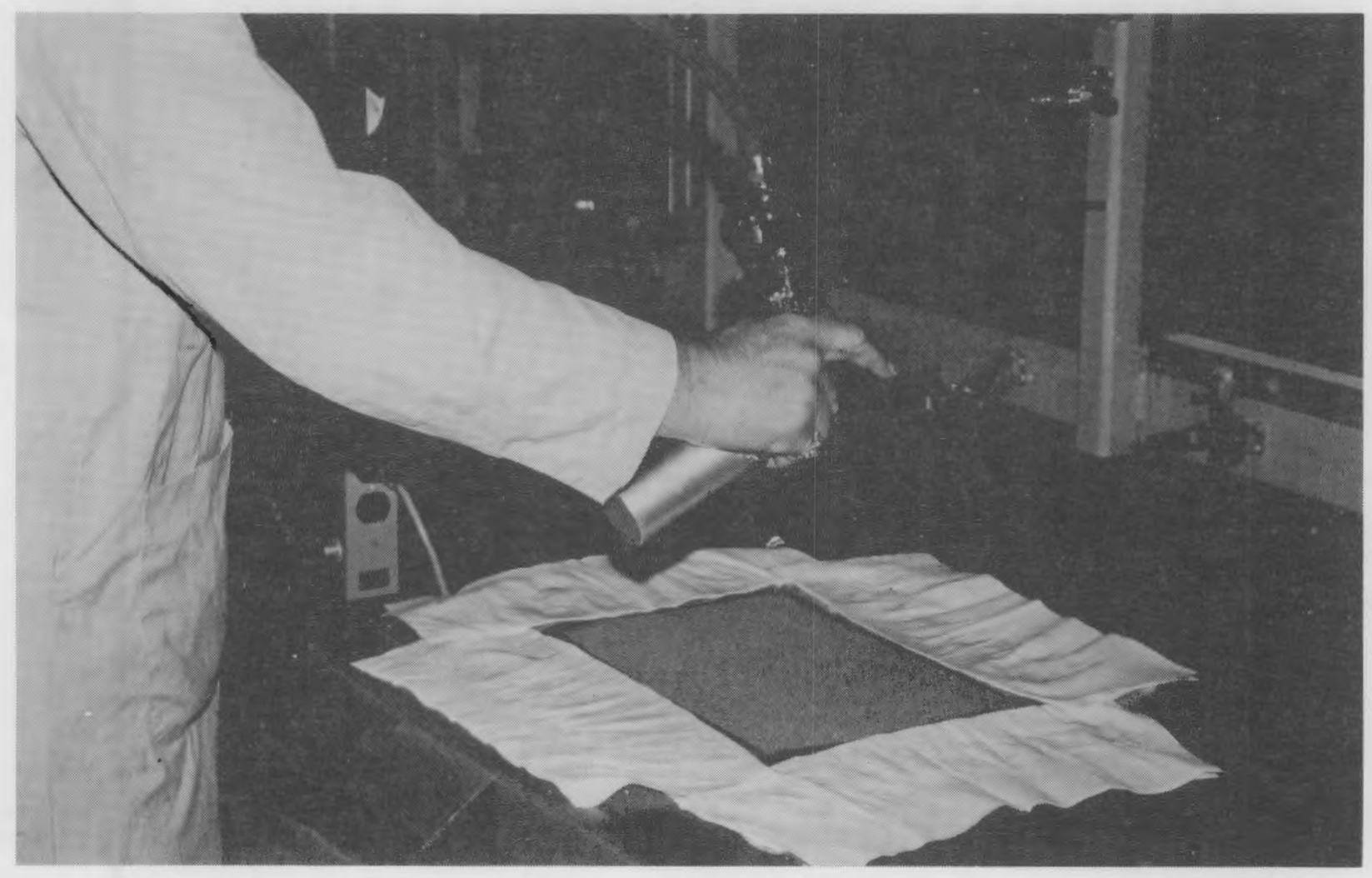

FIGURE 2. Spraying Stabilizers on Sand Samples for Wind Tunnel Tests 
After the curing period, the samples were reweighed and subjected to a variety of tests using a large wind tunnel (Figure 3 ). The wind tunnel had a 9.1-m long test section with a $0.6 \times 0.6-m$ cross section and was capable of generating winds in excess of $27 \mathrm{~m} / \mathrm{s}$. A floor panel in the middle of the test section was removed and replaced with a stainless steel cutout to hold the sample pan level with the floor of the wind tunnel. The sample pan was placed in the cutout and the edges were taped to minimize any turbulence caused by obstructions in the airflow around the sample. Figure 4 shows a sample pan being placed in the wind tunnel for testing.

The sample was placed in the tunnel, the turbine was started, and the wind speed across the sample was gradually increased until sand erosion occurred or a wind velocity of $27 \mathrm{~m} / \mathrm{s}$ (near the upper 1 imit of the wind tunnel) was reached. The usual test period was $15 \mathrm{~min}$. The sample pans were then removed and weighed, and any weight loss was recorded along with observations made during the test. These results were compared with base-line tests run on untreated pans of sand under the same conditions.

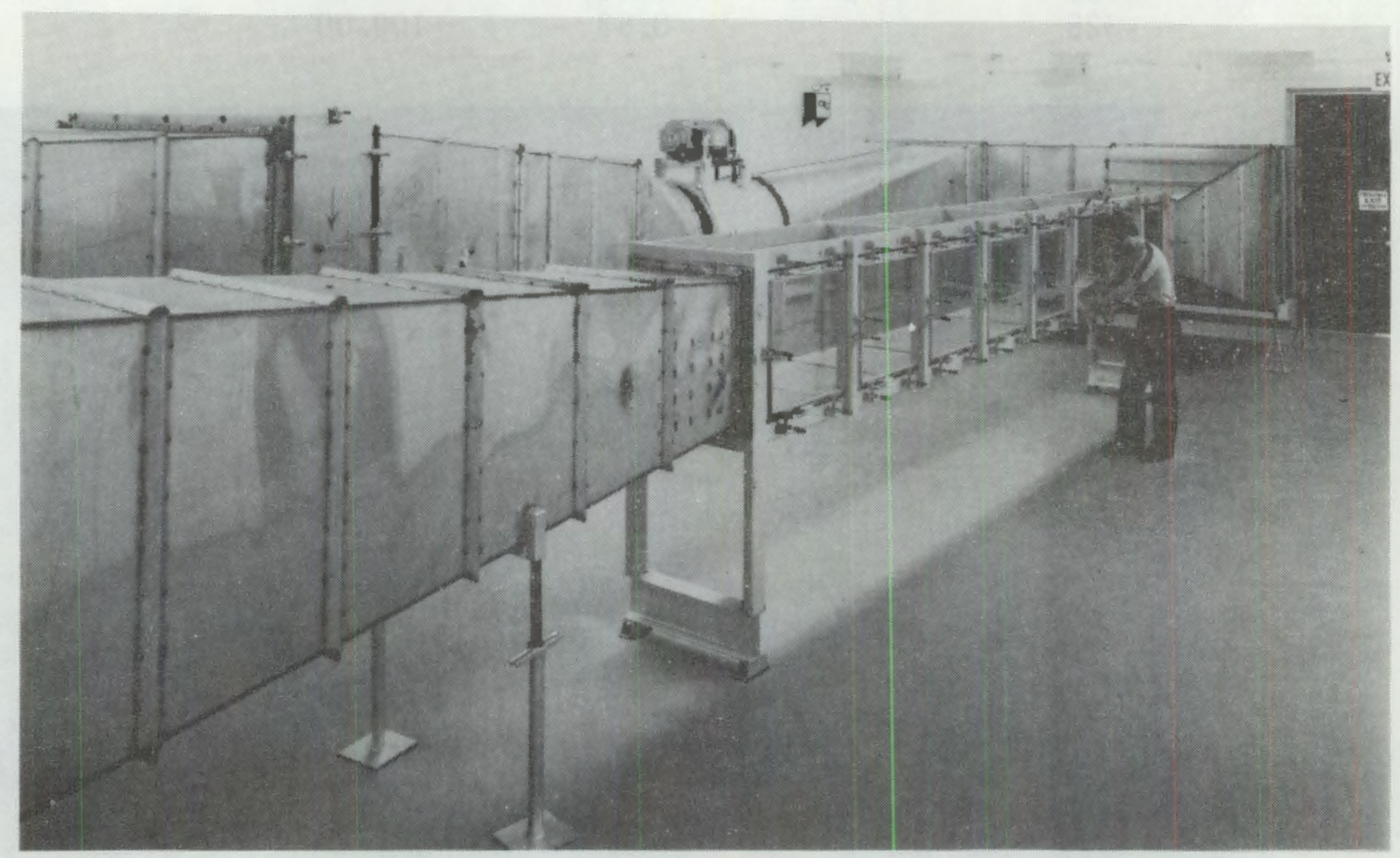

FIGURE 3. Wind Tunnel Used in Laboratory Tests 


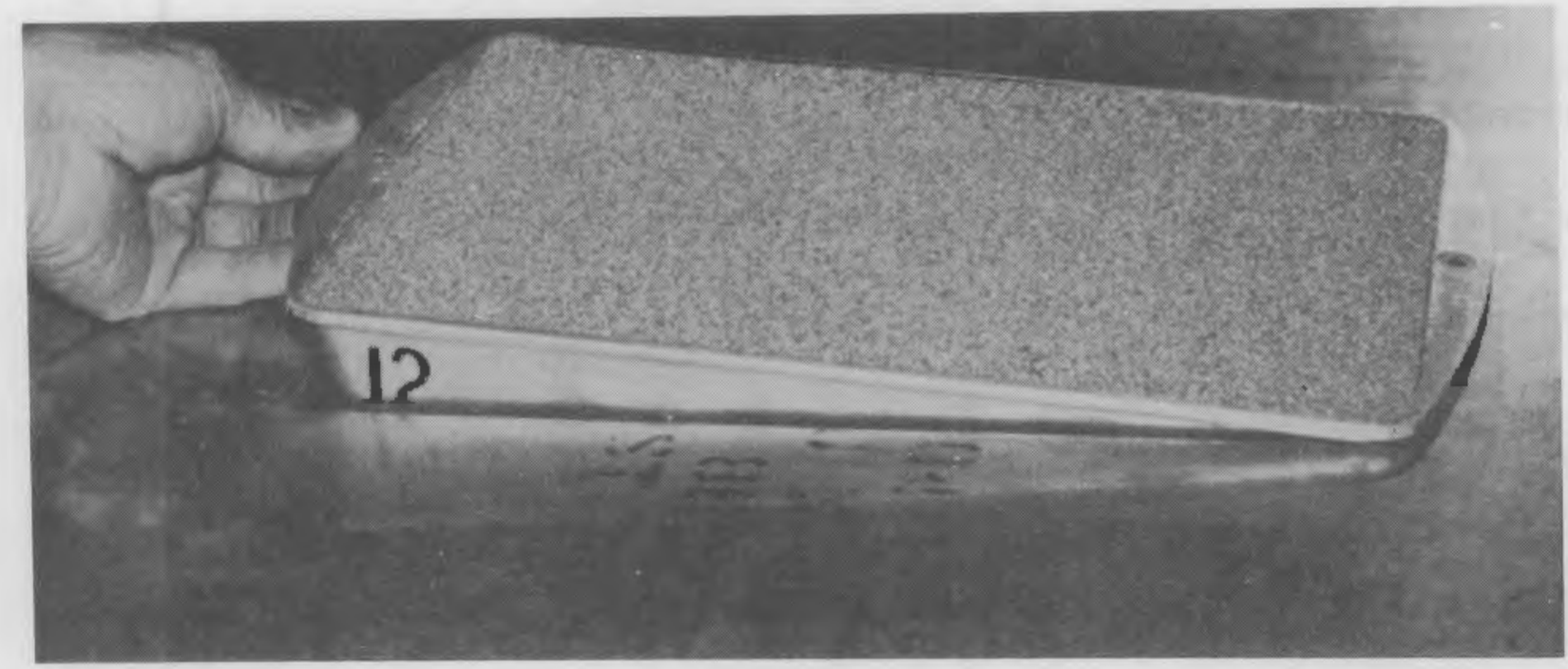

FIGURE 4. Sample Being Inserted in Cutout Floor Section of Wind Tunnel

Similar tests were conducted where the stabilizers were applied in different amounts. One series was run with the stabilizers at half the recommended application, and another series was run where the stabilizers were applied at an equivalent cost per unit of surface area based on material costs supplied by the manufacturers. These costs were the delivered costs for the amount necessary to treat a 40-ha tailings pile at a hypothetical mill in central Wyoming. This basis was chosen because unit prices for the stabilizers vary with the total order size and shipping costs are often a significant portion of the total cost.

The stabilizers tested in each series were ranked in order of wind erosion control effectiveness based on weight loss data and observations made during wind tunnel testing. It was initially hoped that as few as six materials would be identified for the subsequent field test; however, results from these pre1 iminary screening tests indicated that 14 of the 34 chemical stabilizers were equally effective and superior to the remainder of those tested. These stabilizers (Table 2) were selected for the field test.

One additional stabilizer, Hydro Mulch, was also included in the field test. This stabilizer is a wood fiber material that is applied to the surface of the soil to decrease wind erosion. Its effectiveness is increased by mixing a binder, usually some type of organic glue, with the fiber slurry to bind it to the surface of the soil. It is then slurried with water and sprayed onto the soil surface. It was not tested in the laboratory because no suitable method for accurately applying the wood fiber slurry to the small pans was found during the brief period of laboratory testing. 


\section{TABLE 2. Stabilizers Selected for Field Test}

\begin{tabular}{|c|c|c|}
\hline Stabilizer & Manufacturer & Composition (a) \\
\hline Aerospray-70 & $\begin{array}{l}\text { American Cyanamid Co., Wayne, } \\
\text { New Jersey }\end{array}$ & $\begin{array}{l}\text { Synthetic polymer emulsion; } \\
\text { polyvinyl acetate }\end{array}$ \\
\hline Dust Loc VMX-50 & $\begin{array}{l}\text { American Energy, Pico Rivera, } \\
\text { California }\end{array}$ & $\begin{array}{l}\text { Synthetic polymer emulsion; } \\
\text { acrylic latex }\end{array}$ \\
\hline Polyco 2151 & $\begin{array}{l}\text { Borden Chemicals, Compton, } \\
\text { California }\end{array}$ & $\begin{array}{l}\text { Synthetic polymer emulsion; } \\
\text { vinyl acetate/acrylic } \\
\text { copolymer }\end{array}$ \\
\hline M-167 & $\begin{array}{l}\text { Dowe11/Dow Chemical, Denver, } \\
\text { Colorado }\end{array}$ & $\begin{array}{l}\text { Synthetic polymer emulsion; } \\
\text { latex, wetting agent, } \\
\text { propylene glycol }\end{array}$ \\
\hline$S P-400$ & $\begin{array}{l}\text { Johnson and March Corporation, } \\
\text { Philadelphia, Pennsylvania }\end{array}$ & $\begin{array}{l}\text { Synthetic polymer emulsion; } \\
\text { latex emulsion (proprietary) }\end{array}$ \\
\hline Marloc & $\begin{array}{l}\text { Reclamare Co., Seattle, } \\
\text { Washington }\end{array}$ & $\begin{array}{l}\text { Synthetic polymer emulsion; } \\
\text { polyvinyl acetate }\end{array}$ \\
\hline Wallpol $40-133$ & $\begin{array}{l}\text { Reichold Chemicals, Inc., } \\
\text { Tacoma, Washington }\end{array}$ & $\begin{array}{l}\text { Synthetic polymer emulsion; } \\
\text { vinyl acetate/acrylic } \\
\text { copolymer }\end{array}$ \\
\hline Dust Binder $\mathrm{C}-266$ & $\begin{array}{l}\text { Union Carbide Corporation, } \\
\text { Long Beach, California }\end{array}$ & Synthetic polymer emulsion \\
\hline Soil Gard & $\begin{array}{l}\text { Walsh Chemicals, Philadelphia, } \\
\text { Pennsylvania }\end{array}$ & $\begin{array}{l}\text { Synthetic polymer emulsion; } \\
\text { styrene butadiene }\end{array}$ \\
\hline CPB-12 & $\begin{array}{l}\text { Wen Don Corporation, Price, } \\
\text { Utah }\end{array}$ & $\begin{array}{l}\text { Synthetic polymer emulsion; } \\
\text { aqueous acrylic emulsion } \\
\text { with conditioners }\end{array}$ \\
\hline Sandstill II & $\begin{array}{l}\text { Energy Systems, McLean, } \\
\text { Virginia }\end{array}$ & $\begin{array}{l}\text { Petroleum resin emulsion; } \\
\text { petroleum resins/wetting } \\
\text { agent }\end{array}$ \\
\hline Coherex & $\begin{array}{l}\text { Witco Chemical Co., } \\
\text { Bakersfield, California }\end{array}$ & $\begin{array}{l}\text { Petroleum resin emulsion; } \\
\text { petroleum oils and resins/ } \\
\text { wetting agents }\end{array}$ \\
\hline Orzan A & $\begin{array}{l}\text { Crown Zellerbach, Vancouver, } \\
\text { Washington }\end{array}$ & $\begin{array}{l}\text { Lignin sulfonate; } \\
\text { ammonium ligin sulfonate }\end{array}$ \\
\hline Dust Gard & $\begin{array}{l}\text { Great Salt Lake Minerals, } \\
\text { Salt Lake City, Utah }\end{array}$ & Hygroscopic $\mathrm{MgCl}_{2}$ brine \\
\hline Hydro Mulch & $\begin{array}{l}\text { Conwed Corporation, St. Paul, } \\
\text { Minnesota }\end{array}$ & Wood fiber mulch \\
\hline
\end{tabular}

(a) The actual chemical composition of most of the chemical stabilizers is considered to be confidential by the manufacturer. 


\section{APPLICATION EQUIPMENT REVIEW}

One of the preliminary activities of this study was to select a suitable method of stabilizer application. Since all the chosen chemical stabilizers were to be applied as liquids, a suitable spraying system was required. The proper sprayer had to satisfy certain technical and practical constraints.

\section{Stabilizer Constraints}

The materials chosen as the candidate stabilizers for the field test covered a wide variety of compositions, including: synthetic polymer emulsions, petroleum resin emulsions, lignin sulfonate, and a concentrated chloride solution. In choosing a sprayer system, the corrosion resistance of the sprayer was a consideration. The magnesium chloride solution, for instance, is potentially very corrosive. The different types of materials necessitated having a delivery system that could be easily and thoroughly cleaned between each application.

All but one of the stabilizers were highly diluted with water, and the resulting viscosities were nearly that of water. No special considerations regarding highly viscous solutions were necessary in selecting the sprayer. The magnesium chloride solution was not diluted; it was to be applied full strength as delivered. Although the solution density was much higher than the others, the viscosity was not much different.

Test Site Constraints

The rather remote location of the field test required that the application system be self-contained and portable. Additionally, the system had to operate on the surface of the unconsolidated tailings pile. Most important was the ability of the sprayer to cover the tailings pile uniformly.

\section{Equipment Selection}

Various spray systems were considered for the field test, including several airless sprayers, compressed air sprayers, gas and power-takeoff field sprayers, sprayers with hose and nozzle delivery systems, and others with boomtype spray bars. The most suitable sprayer--and the one chosen for the field test--was a boom-type field sprayer pulled behind a tractor. The Pul-Tank sprayer had a 380-l stainless steel agitated storage tank and a pump powered by a small gasoline engine (Figure 5). The sprayer output was adjustable through a recycle valve. Stabilizer application to the test plots was also adjustable by varying the speed of the tractor. Calibration of the sprayer and application of the stabilizers are described in more detail in later sections.

(3) Manufactured by Rear's Manufacturing Co., Eugene, Oregon. 


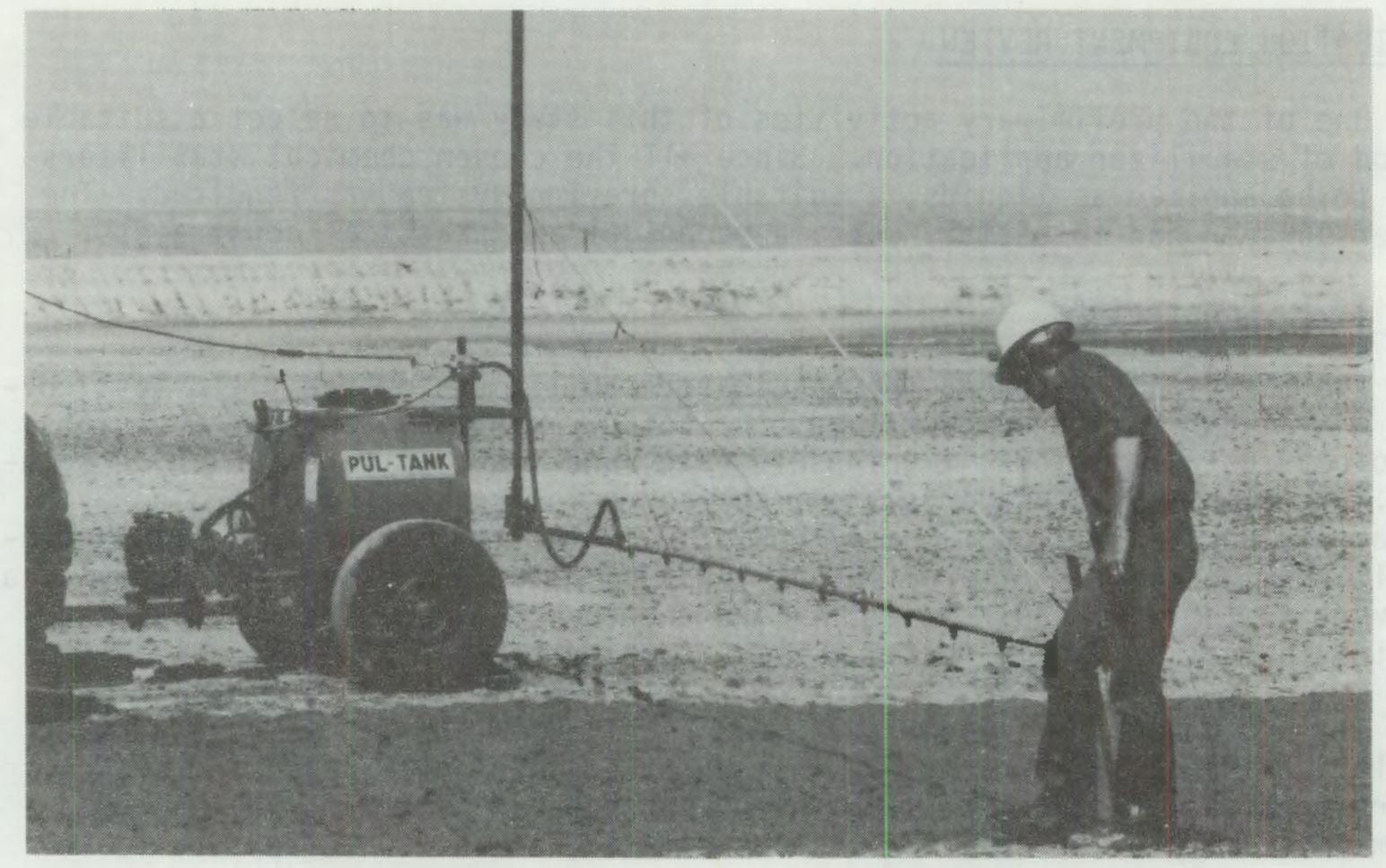

FIGURE 5. Application of Chemical Stabilizers with a Small Field Sprayer

\section{FIELD TEST SITE SELECTION}

While the laboratory screening tests were being conducted, a number of active uranium mills were visited to locate a suitable field test site for the stabilizer testing. The following criteria were established for the field test site:

- The test site should be on a currently or recently active tailings pile.

- The test site should be on the beach area of a tailings pile and if possible should be located on the prevailing windward side of the pile.

- The test site should be in an area that could be left undisturbed for 2 to 3 years for monitoring.

- Since the majority of mills use an acid leach process, the test site should be located at one of these mills.

The eight mills visited for site selection are shown in Table 3. of these, one mill was particularly well suited for the field test: the Federal American Partners Mill (FAP), Gas Hills, Wyoming. This acid leach process mill had been recently shut down; therefore, tailings were no longer being deposited 
TABLE 3. Uranium Mills Considered for Field Test

\begin{tabular}{|c|c|}
\hline Mill & Location \\
\hline Union Carbide Corporation & Uravan, Colorado \\
\hline Kerr-McGee Corporation & Grants, New Mexico \\
\hline Atlas Corporation & Moab, Utah \\
\hline Rio Algom Corporation & LaSal, Utah \\
\hline Federal American Partners & Gas Hills, Wyoming \\
\hline Lucky Mc Pathfinder & Gas Hills, Wyoming \\
\hline Union Carbide Corporation & Gas Hills, Wyoming \\
\hline Western Nuclear & Gas Hills, Wyoming \\
\hline
\end{tabular}

on the tailings pile. The tailings pile has a wide, flat beach area on its south-southwest side, which faces into the prevailing wind. The entire pile is raised above the surrounding area for maximum weather exposure. At the time the site selection was made, personnel at the mine indicated that it would be at least a few years before production resumed. This delay would allow adequate time for continued monitoring of the test site. Much of the equipment required for the field test was available for PNL use at the site. A particular benefit was the availability of a hydroseeder, which is designed for applying Hydro Mulch and similar materials. It consists of an agitated tank and a high-pressure pump. The availability of the hydroseeder allowed the inclusion of the wood fiber mulch stabilizer in the list of field-tested stabilizers. 



\section{FIELD TEST ACTIVITIES}

Once the preliminary activities of selecting the stabilizers, the application system, and a field test site were completed, the following activities were conducted at the FAP mill site, Gas Hills, Wyoming. The installation of the field test was carried out from August 23 to September 3, 1982.

\section{TEST SITE PREPARATION}

The field test site was located on the FAP No. 2 tailings pile (Figure 6). This tailings pile is elevated above the surrounding grade allowing maximum exposure to winds from all directions. This location was also convenient for vehicle access and close to the mill buildings where materials and equipment were stored. A portion of the beach area on the south-southwest side of the tailings pile was selected for the test site. This area is shown in Figure 7 in relationship to surrounding features at the mill site.

A short time before the field test began the Wyoming Department of Environmental Quality had required that FAP stabilize their tailings piles in some manner to prevent wind erosion. A small test program performed by FAP prior to this requirement indicated that Orzan, a lignin sulfonate product, would be the most cost-effective material for this task. Several thousand gallons of the product were applied to as much of the tailings pile as could be reached; some

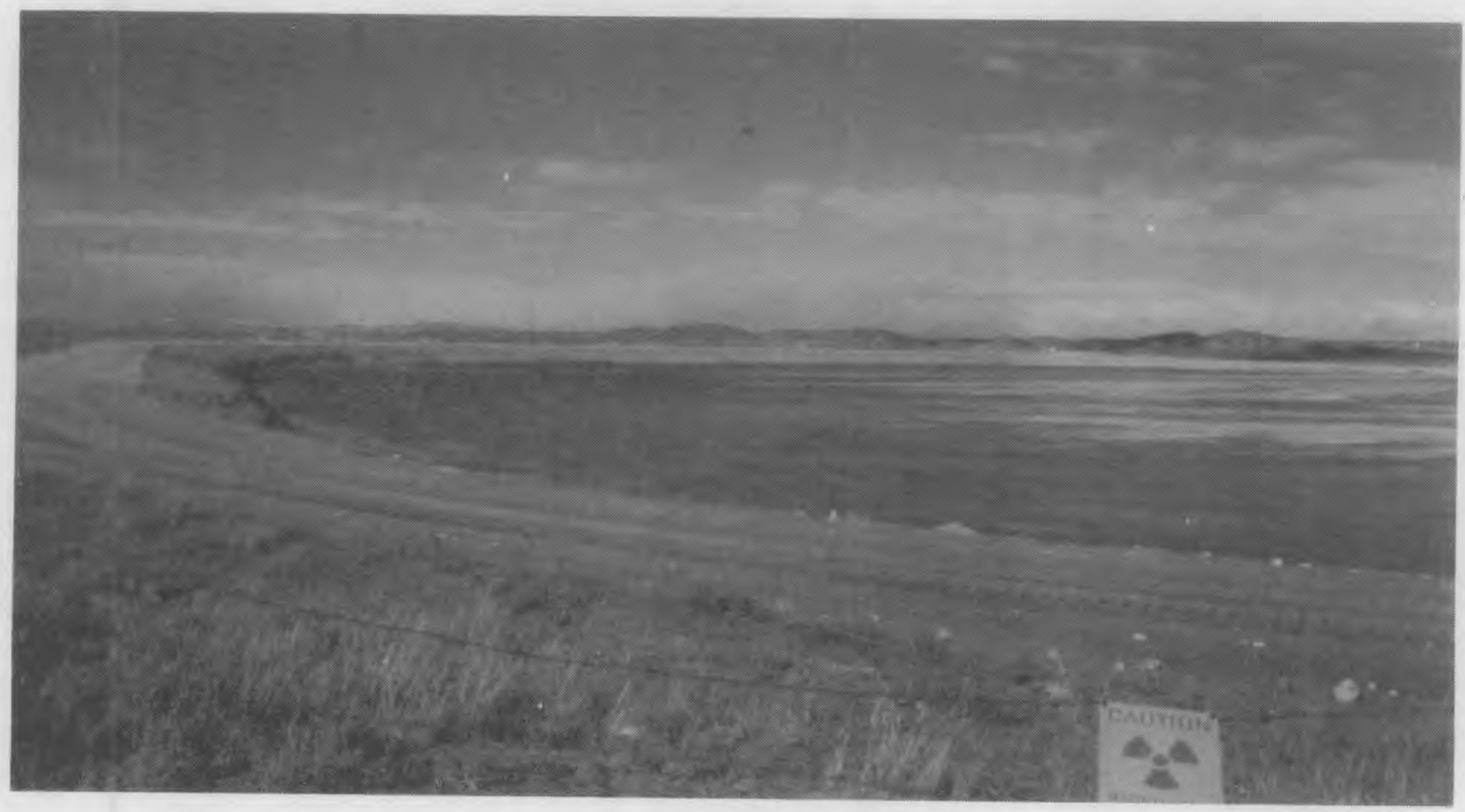

FIGURE 6. Federal American Partners Tailings Pile, Gas Hills, Wyoming 


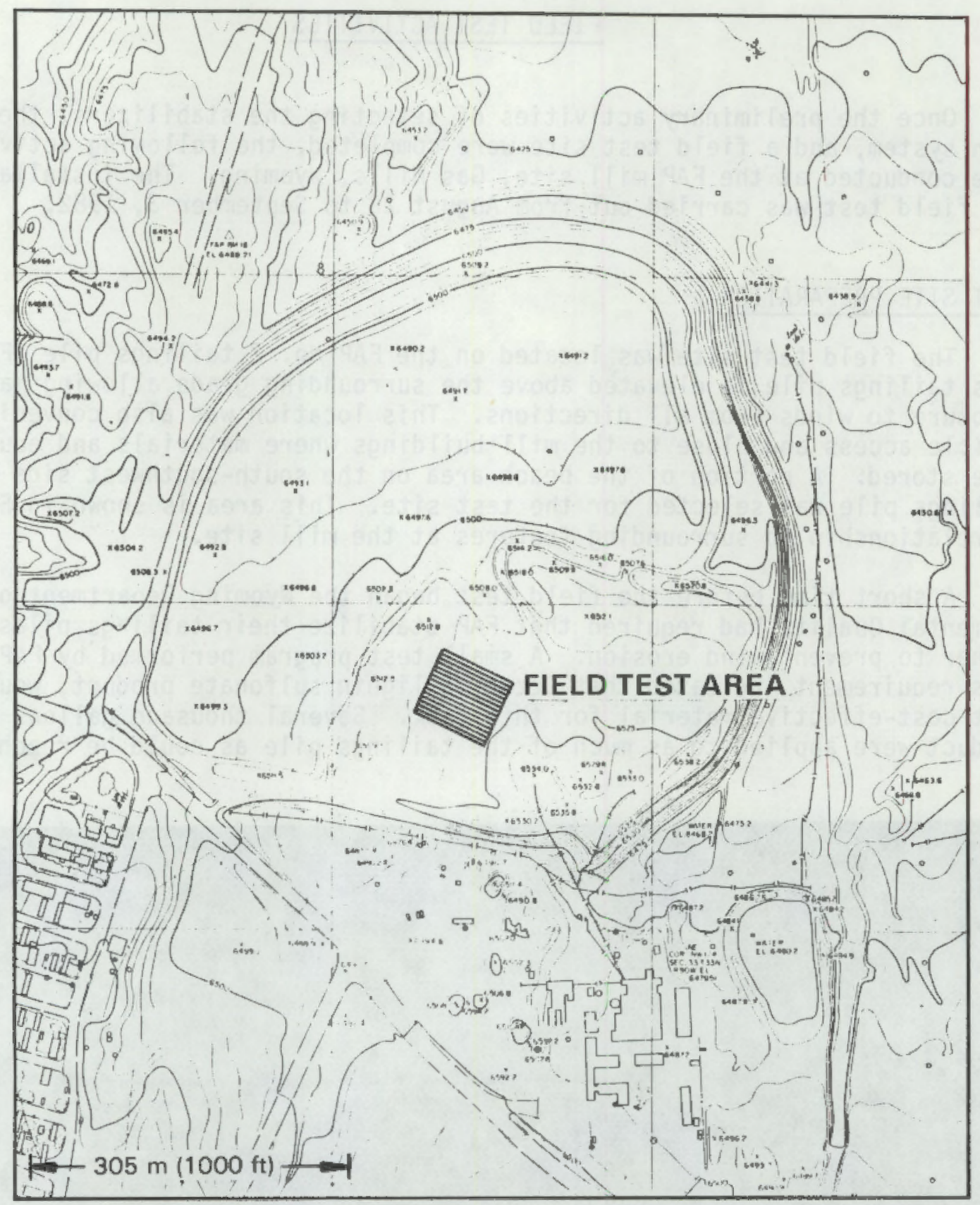

FIGURE 7. Plan View of Field Test Site on FAP Tailings Pile and Surrounding Features 
of the pond area was still wet and inaccessible to the spraying equipment. The lignin sulfonate was sprayed from a tank truck fitted with a high-pressure pump and a hand-held hose. The stabilizer effectively protected the treated portion of the tailings pile from further erosion, but the durability of the material was not certain. Because of the lignin sulfonate on the tailings surface, the top 5-cm layer of tailings was removed for the field test. However, the stabilized area surrounding the test plot minimized the amount of tailings that might be blown onto the test area from the rest of the pile.

For the field test, an area slightly larger than the subsequent test plot was prepared. Several cross-sectional samples of the surface showed -1 to $2 \mathrm{~cm}$ of penetration by the stabilizer. The Orzan had been applied to the tailings -1 month earlier, and very little rain had fallen to cause further penetration of the stabilizer. A motor-grader removed the top $-5 \mathrm{~cm}$ of tailings and pushed them to the north side of the test plot. The tailings with the orzan were a much darker color than the untreated tailings, which allowed the grader operator to effectively remove all of the stabilized tailings, leaving an exposed surface of untreated tailings for the field test. Surface removal operations with the grader are shown in Figure 8.

The grader left a very uneven, undesirable surface of deep tire tracks and small windrows of tailings. Therefore, the test area was leveled and smoothed by several passes of a tractor and disk, followed by a tractor and harrow (Figures 9 and 10). This procedure produced a very level and more compacted surface that made subsequent stabilizer application much easier.

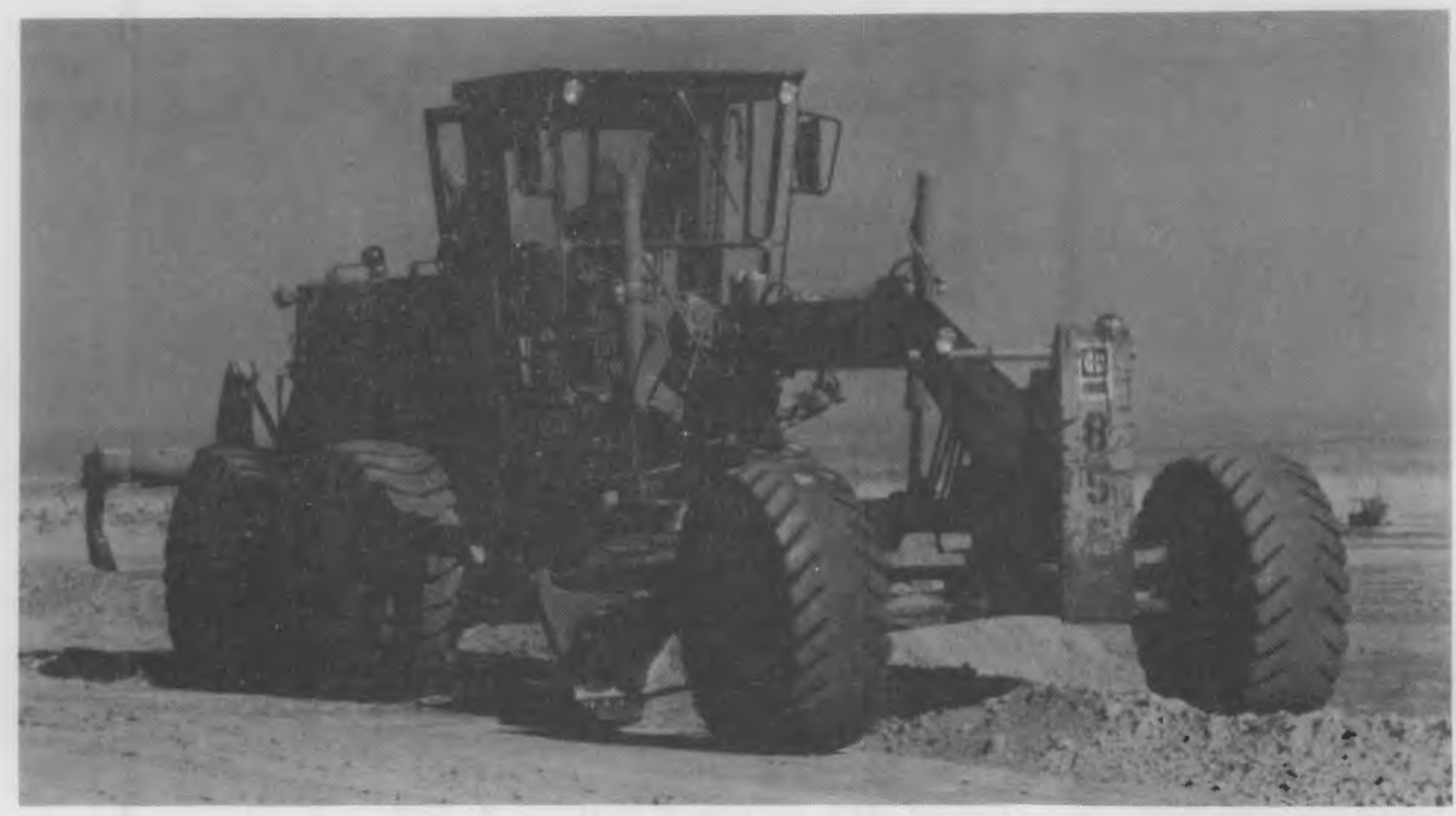

FIGURE 8. Grader Removing Treated Surface Tailings from Test Plot Area 


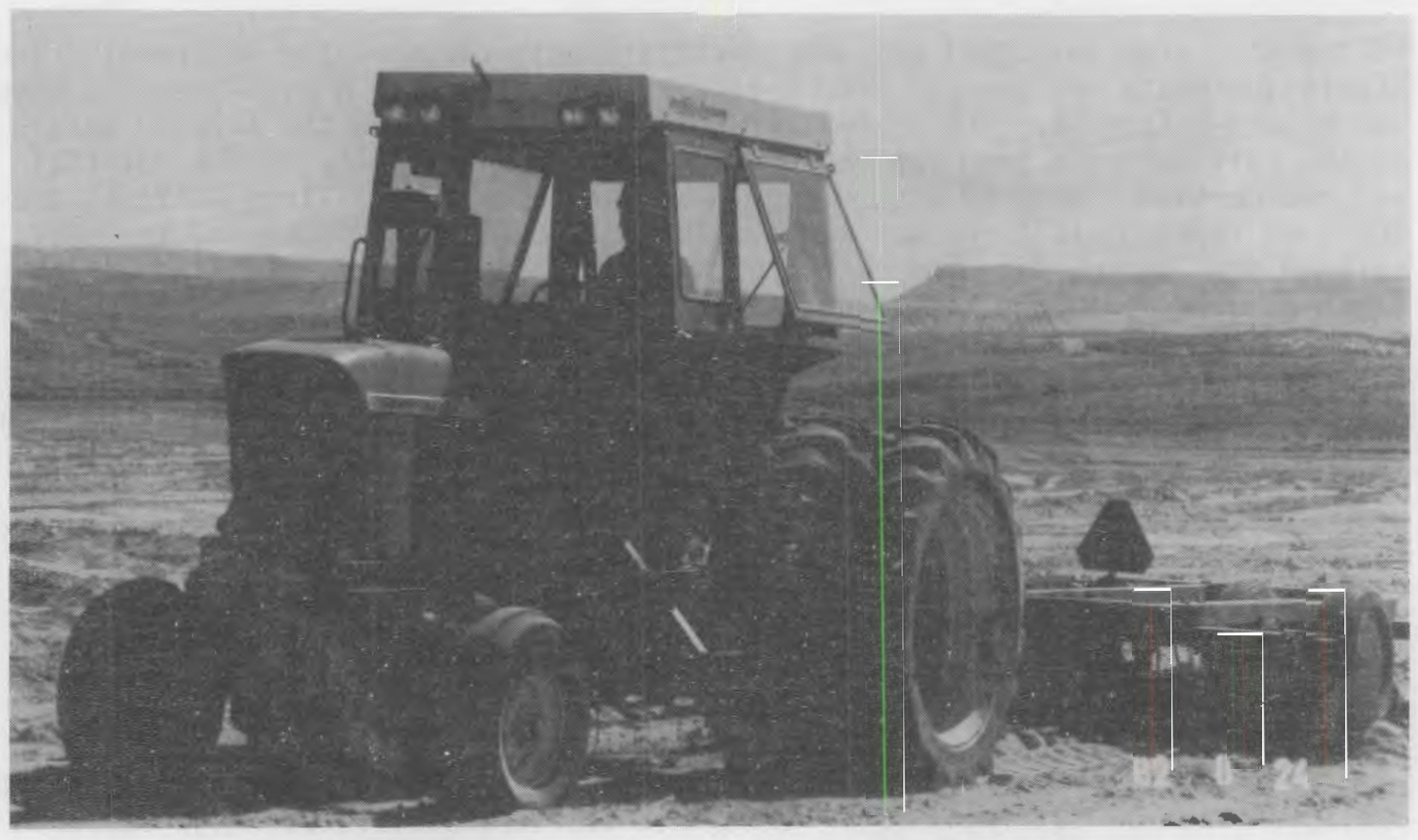

FIGURE 9. Tractor and Disk Leveling Test Plot Area

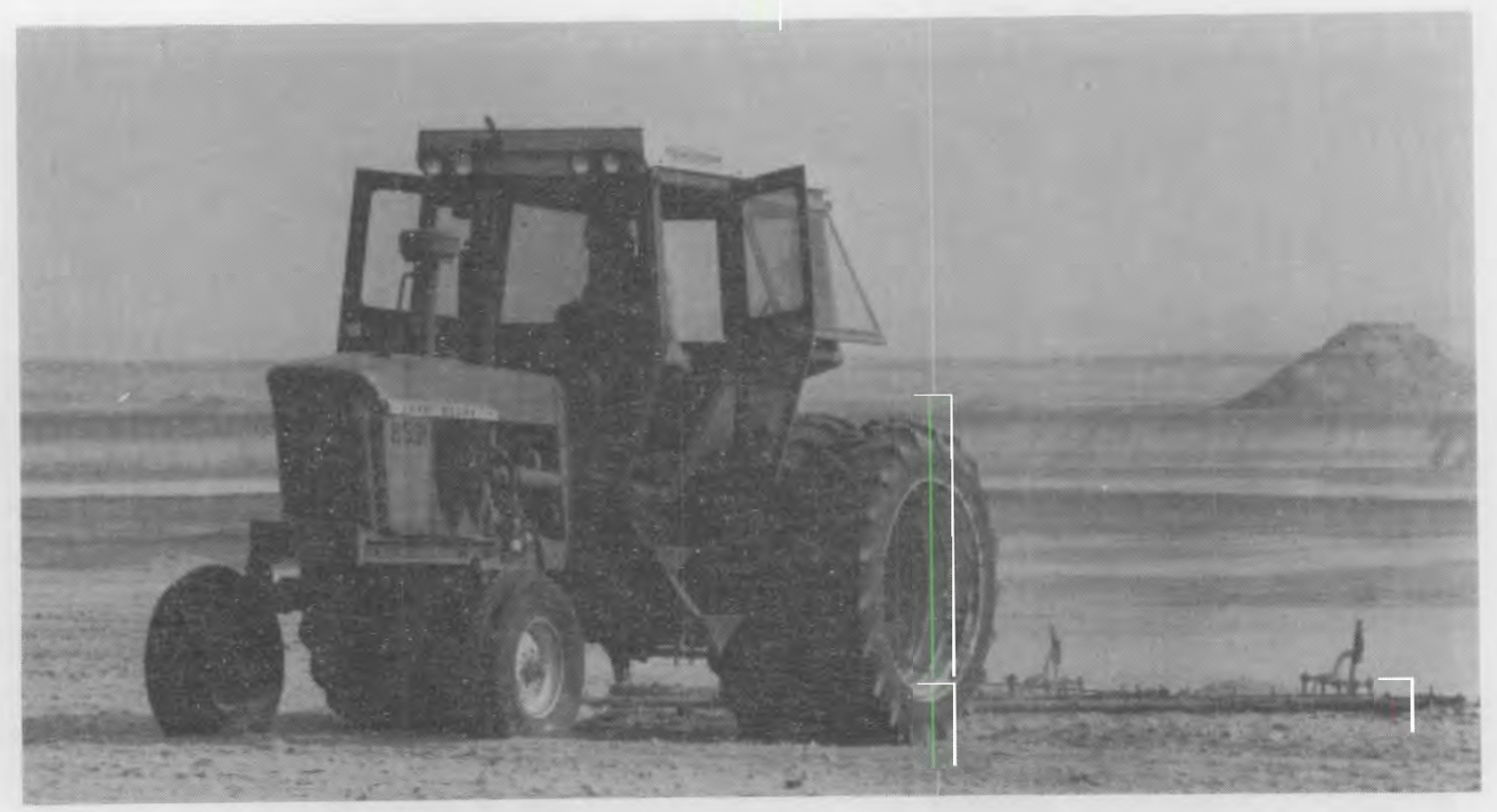

FIGURE 10. Tractor and Harrow Preparing a Smooth Surface on Test Plot Area 
The perimeter of the actual test site was marked by an FAP survey crew. The overall test area measured $87 \times 66 \mathrm{~m}$ and was composed of 30 subplots, each $6 \times 18.45 \mathrm{~m}$. Access strips for driving on the test area were placed between each test plot. Weather data for this area indicated that the prevailing winds occur out of the south-southwest; therefore, the test area was oriented with the length of the subplots aligned in this direction. Figure 11 shows the test area layout and the locations of the weather station and the five moisture sensors.

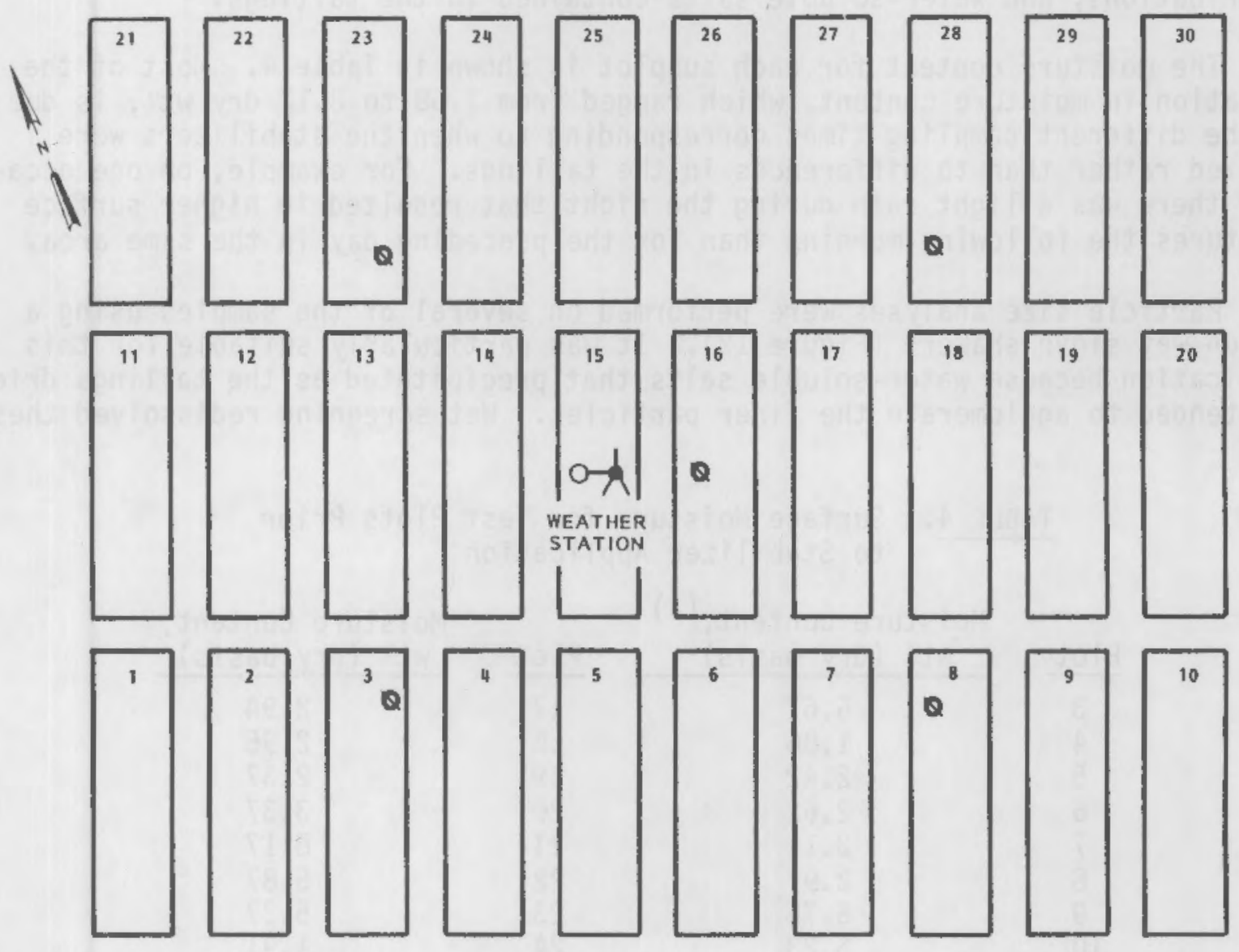

FIGURE 11. Field Test Area Consisting of 30 Test Plots 


\section{TEST SITE CHARACTERIZATION}

The stabilizers were applied over a period of a few days that included varying weather conditions. Each subplot was sampled just before the stabilizer was applied so that the moisture content of the tailings surface was known at the time of application. Surface samples were taken to a depth of $-5 \mathrm{~cm}$ from five places on each subplot and combined into one composite sample. This composite sample was then split into smaller samples that were used for several characterization studies, including moisture analyses, particle size distributions, and water-soluble salts contained in the tailings.

The moisture content for each subplot is shown in Table 4. Most of the variation in moisture content, which ranged from 1.58 to 8.17 dry wt\%, is due to the different sampling times corresponding to when the stabilizers were applied rather than to differences in the tailings. For example, on one occasion there was a light rain during the night that resulted in higher surface moistures the following morning than for the preceding day in the same area.

Particle size analyses were performed on several of the samples using a Gilson wet sieve shaker (Figure 12). It was particularly suitable for this application because water-soluble salts that precipitated as the tailings dried out tended to agglomerate the finer particles. Wet screening redissolved these

TABLE 4. Surface Moisture for Test Plots Prior to Stabilizer Application

\begin{tabular}{|c|c|c|c|}
\hline Plot & $\begin{array}{l}\text { Moisture Content, } \\
\text { wt\% (dry basis) } \\
\end{array}$ & Plot & $\begin{array}{l}\text { Moisture Content, } \\
\text { wt\% (dry basis) }\end{array}$ \\
\hline $\begin{array}{r}3 \\
4 \\
5 \\
6 \\
7 \\
8 \\
9 \\
10 \\
11 \\
12 \\
13 \\
14 \\
15 \\
16\end{array}$ & $\begin{array}{l}5.67 \\
1.86 \\
2.42 \\
2.62 \\
2.11 \\
2.97 \\
5.76 \\
5.23 \\
6.99 \\
7.06 \\
5.79 \\
2.61 \\
2.64 \\
2.80\end{array}$ & $\begin{array}{l}17 \\
18 \\
19 \\
20 \\
21 \\
22 \\
23 \\
24 \\
25 \\
26 \\
27 \\
28 \\
29 \\
30\end{array}$ & $\begin{array}{l}2.94 \\
2.95 \\
2.37 \\
3.37 \\
8.17 \\
5.87 \\
5.37 \\
1.91 \\
2.12 \\
1.75 \\
1.90 \\
2.34 \\
1.99 \\
1.58\end{array}$ \\
\hline
\end{tabular}

(a) Moisture in top $6 \mathrm{~cm}$ of tailings.

(8) Manufactured by Gilson Company, Inc., Worthington, Ohio. 


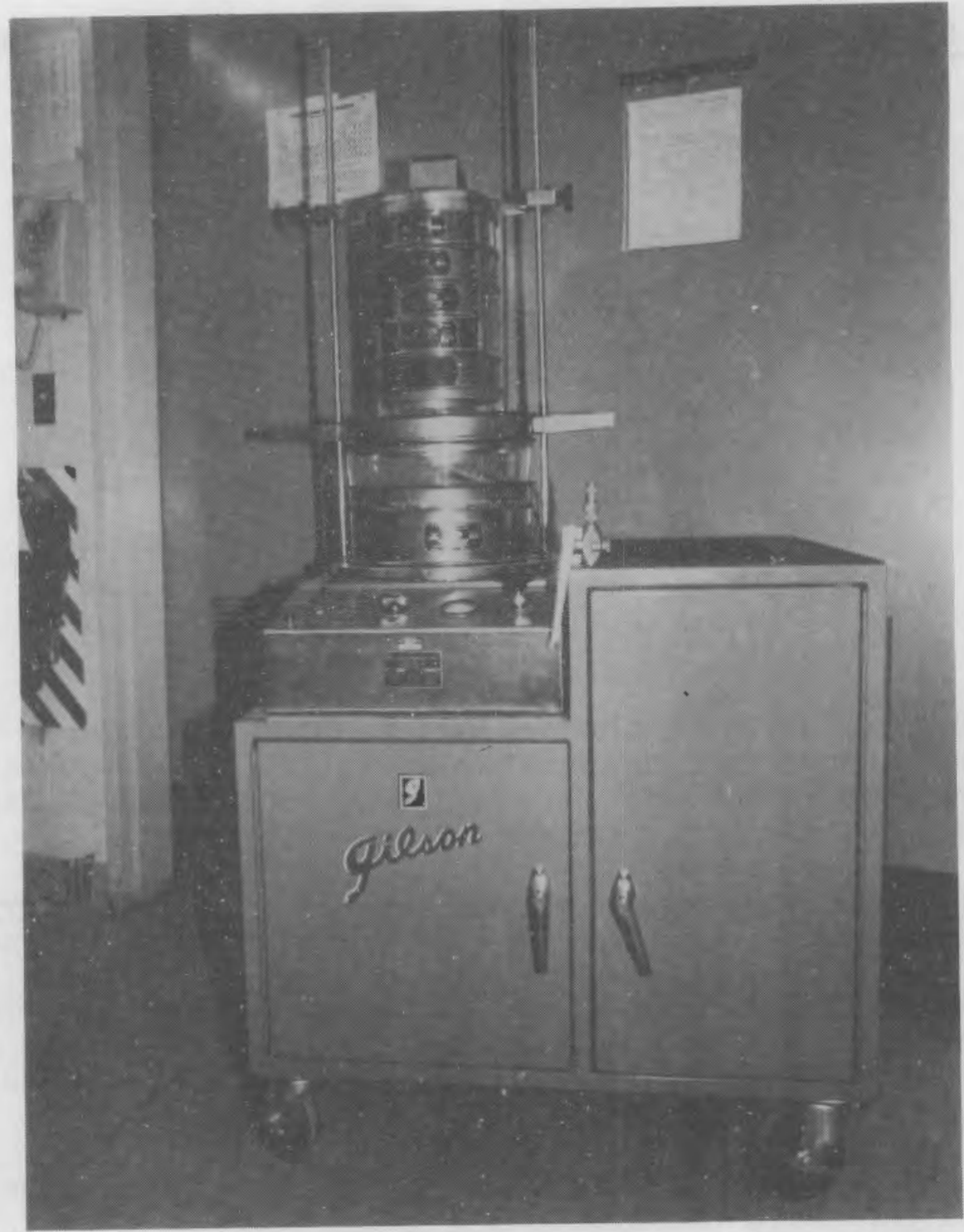

FIGURE 12. Gilson Wet Sieve Shaker Used for Tailings Particle Size Distribution Studies

salts, giving a more accurate size distribution of the material. Size distribution determinations indicated that the material on the surface of the test plot was very uniform (Table 5 ).

Since the stabilizers were applied as water solutions, water-soluble salts in the tailings may be detrimental to the effectiveness of the stabilizers by redissolving and reacting with them. Water-soluble salts were determined as part of the characterization studies. Tailings samples were divided into 60to $85-\mathrm{g}$ samples and then leached with deionized water in a stirred beaker for $10 \mathrm{~min}$ at room temperature $\left(-21^{\circ} \mathrm{C}\right)$. These leach tests were done at a pulp 
TABLE 5. Size Distribution Analysis for Test Plot Surface Samples

\begin{tabular}{|c|c|c|c|c|}
\hline \multirow[b]{3}{*}{ Mesh } & \multirow{3}{*}{$\begin{array}{c}\text { Opening } \\
\text { Size }\end{array}$} & \multirow{3}{*}{$\begin{array}{c}\text { Average } \\
\text { Cumulative } \\
\text { wt\% Retained } \\
\end{array}$} & \multicolumn{2}{|c|}{ Range } \\
\hline & & & of wt & etained \\
\hline & & & Low & High \\
\hline 12 & $1.70 \mathrm{~mm}$ & 3.74 & 1.44 & 5.32 \\
\hline 16 & $1.18 \mathrm{~mm}$ & 11.82 & 6.25 & 9.86 \\
\hline 20 & $850 \mu \mathrm{m}$ & 23.63 & 10.34 & 14.15 \\
\hline 30 & $600 \mathrm{rm}$ & 38.56 & 13.48 & 16.91 \\
\hline 40 & 425 um & 55.20 & 15.47 & 17.41 \\
\hline 50 & 300 um & 68.45 & 11.81 & 15.47 \\
\hline 70 & 212 um & 76.09 & 6.71 & 8.70 \\
\hline 100 & 150 Im & 82.12 & 4.73 & 6.80 \\
\hline 140 & $106 ~ \mu \mathrm{m}$ & 85.67 & 2.56 & 4.13 \\
\hline 200 & 75 นm & 88.09 & 1.71 & 2.88 \\
\hline 270 & $53 \mu \mathrm{m}$ & 89.32 & 0.84 & 1.49 \\
\hline 325 & $45 \quad \mu m$ & 90.24 & 0.28 & 0.41 \\
\hline
\end{tabular}

density of $10 \mathrm{wt} \%$ solids. The slurries were filtered through 10- Im filter paper, and the filtrate solutions were analyzed for dissolved anions by ion chromatography (IC) and for metal ions by induction-coupled plasma spectrometry (ICP). Results of the solution analyses are shown in Table 6.

Charge balances calculated from these solution analyses are very near unity, indicating that no major species were omitted from the analyses. These data suggest that water-soluble salts in the tailings at the time of sampling, and therefore when the stabilizers were applied, were primarily sulfates of aluminum, calcium, iron, and magnesium. One anomaly appeared to be magnesium chloride in the sample from Plot 20. Chloride was nil and magnesium was much lower for the other samples.

With the exception of the magnesium chloride in the Plot 20 sample, characterization studies show that the surface tailings were quite uniform, both

TABLE 6. Water-Soluble Salt Analyses of Test Plot Surface Samples

Concentration of Water-Soluble Salts, $\mathrm{mg} / \mathrm{g}$-tailings

\begin{tabular}{|c|c|c|c|c|c|c|}
\hline Plot & AT & $\mathrm{Ca}$ & $\mathrm{Fe}$ & $\mathrm{Mg}$ & $\mathrm{SO}_{4}$ & CI \\
\hline 12 & 0.20 & 4.90 & 0.55 & 0.10 & 15.45 & - \\
\hline 16 & 0.58 & 5.50 & 1.60 & 0.32 & 24.28 & -- \\
\hline 20 & 0.27 & 4.60 & 0.75 & 1.70 & 19.87 & 2.49 \\
\hline 23 & 0.20 & 5.10 & 0.71 & 0.10 & 17.08 & \\
\hline 27 & 0.29 & 2.20 & 1.40 & 0.16 & 12.20 & -- \\
\hline
\end{tabular}


physically and chemically. The potential effects of water-soluble salts on the effectiveness of the stabilizers are being studied but have not yet been determined.

\section{TEST SITE INSTRUMENTATION}

A self-contained remote weather station (Figure 13) was installed to monitor meteorological conditions, and instrumentation was added to monitor the temperature and moisture content of the tailings surface in the test area. Gypsum moisture blocks were placed in five of the plots just beneath the surface of the tailings to monitor moisture (Figure 11). The moisture blocks were buried prior to spraying the stabilizers so that once the stabilizers were applied the test plot surface would not be disturbed.

The weather station was erected in the center of the test area on Plot 15 (see Figure 11). Meteorological conditions monitored by the weather station

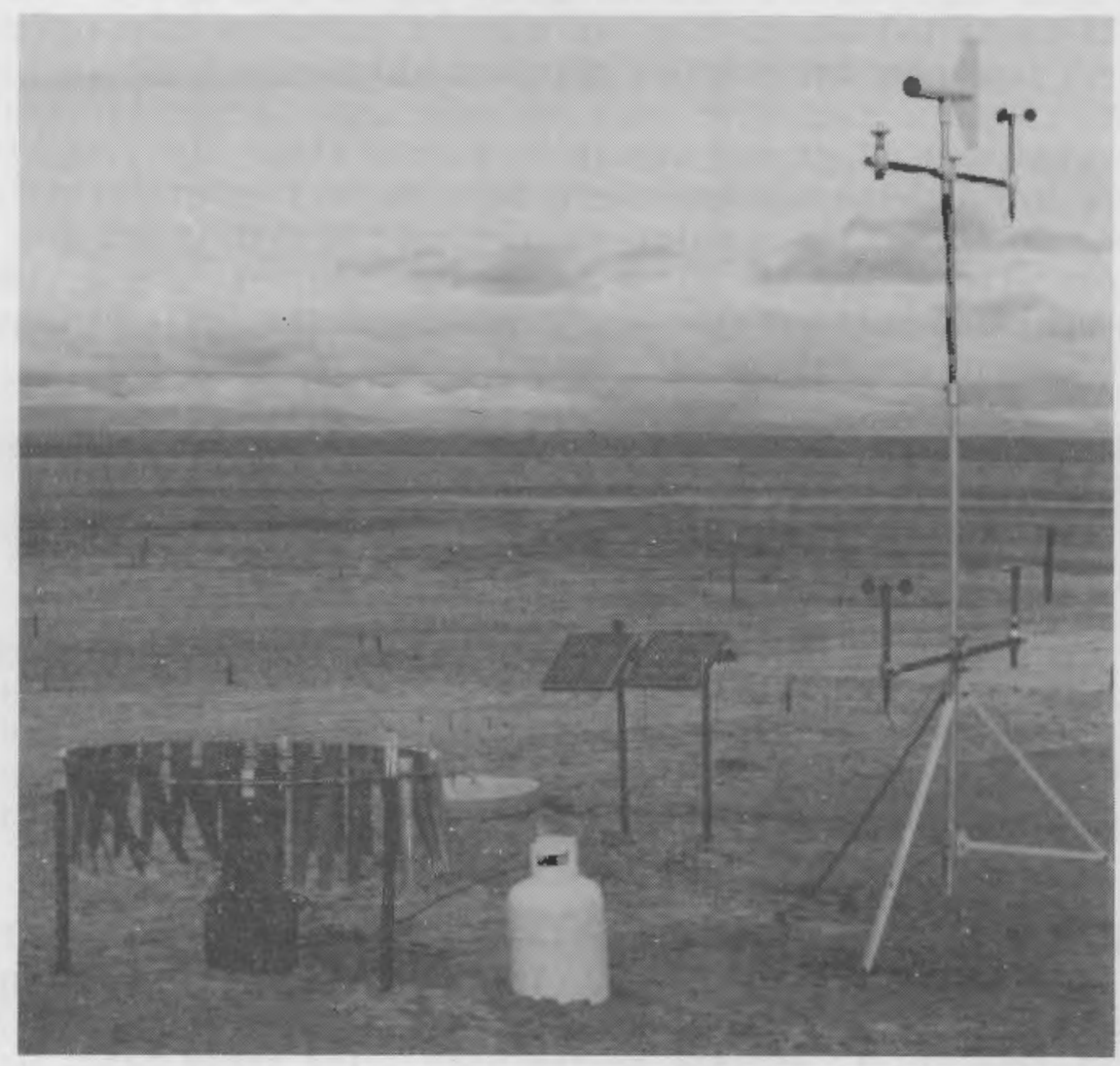

FIGURE 13. Weather Station Installed at Field Test 
include: wind speed ( $1 \mathrm{~m}$ and $3 \mathrm{~m}$ above the surface), wind direction, air temperature, relative humidity, solar radiation, precipitation, soil temperature, and soil moisture with a second type of moisture sensor. The precipitation gauge is propane heated to measure snowfall.

A11 instrumentation is connected to two battery-operated data loggers. The data loggers interpret the data received from the sensors through a series of internal programs and store the data on cassette tapes. The tapes are then periodically retrieved for analysis. The data loggers were buried below ground in an insulated steel column to protect them from water and extreme temperatures. Two small solar panels beside the column continually recharge the data logger batteries.

\section{STABILIZER PREPARATION AND APPLICATION}

The chemical stabilizers were shipped as liquids in containers ranging from 19-l pails to 208- $\ell$ drums, depending on the amounts required or the minimum shipment size that would be delivered by the manufacturer. The Hydro Mulch (shipped in 27-kg bales) was to have an organic tackifier already mixed with the wood fiber; however, the product that was shipped did not include the tackifier. Another organic tackifier that had been used in similar applications with an untreated wood fiber was available at the site. This tackifier was mixed with the Hydro Mulch for the field test at $-2.3 \mathrm{~kg}$ of tackifier per $27 \mathrm{~kg}$ of wood fiber. The wood fiber mulch was pretreated with green dye, which allowed the operator to see the fiber on the soil surface and estimate the amount being applied. Ultraviolet light quickly faded the green dye; in a few days, the wood fiber was nearly indistinguishable from the soil.

The hydroseeder used to apply the Hydro Mulch slurry can be used from the back of a truck; the one used for the field test had a $5.7-\mathrm{m}^{3}$ tank and a gasoline-powered high-pressure pump. The slurry was delivered through interchangeable nozzles that can create selected spray patterns.

Plot 1 was treated with $27 \mathrm{~kg}$ of Hydro Mulch and $2.3 \mathrm{~kg}$ of tackifier slurried with 757 \& of water. P1ot 2 was treated with $13.6 \mathrm{~kg}$ of Hydro Mulch and $1.15 \mathrm{~kg}$ of tackifier in 380 l of water. The slurry was applied as evenly as possible to the test plots, but uniform coverage was difficult with this system. Application of the Hydro Mulch with the hydroseeder is shown in Figure 14.

The chemical stabilizers were applied to the remaining test plots with the small field sprayer described earlier. The sprayer was first calibrated with several nozzles. The nozzles dispensed a total of $38 \mathrm{l} / \mathrm{min}$, which was the maximum output from the 12 nozzles on the boom. The spray booms were originally designed to be on each side of the sprayer but were combined into a single $6.1-\mathrm{m}$ boom on the left side of the sprayer. This boom could cover the entire width of the test plot without running the tractor and sprayer on the plot. Because of the long length of the boom, one person supported it at a constant distance from the ground to maintain the same spray pattern on the 


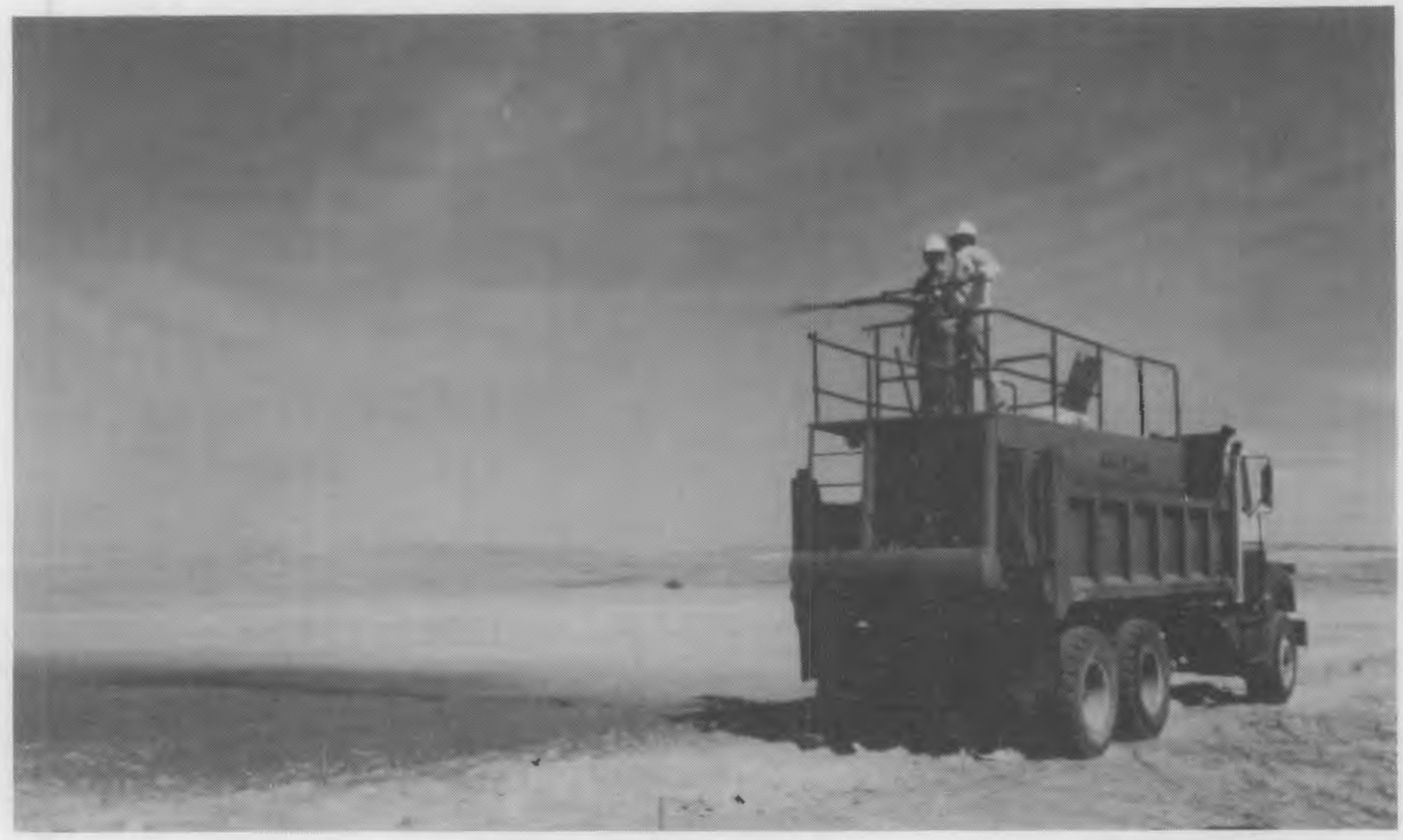

FIGURE 14. Application of Hydro Mulch (wood fiber/water slurry) with Hydroseeder

tailings surface when operating the sprayer on uneven ground. The application rates were changed as necessary by adjusting the speed of the tractor. This method was more accurate than adjusting the sprayer output with the recycle valve. Calibration curves for tractor speed versus engine rpm and gear selection were developed for the range of required ground speeds $(0.9$ to $1.83 \mathrm{~km} / \mathrm{h})$. For each product, the appropriate tractor speed was chosen to require an even number of passes across the test plot. Alternate passes with the sprayer were then made on opposite sides of the test plot. This procedure el iminated uneven application caused by the spray nozzles nearest the pump dispensing more solution than the ones at the outer end of the boom due to friction losses across the boom.

The required amounts of stabilizers were measured and poured into the sprayer tank, and water was added to the sprayer tank from a water truck. The proper diluted volume was determined by a sight-glass tube connected to the side of the tank. The solution was thoroughly mixed by an agitator that was built into the tank and operated by the pump's engine. When the tank was filled, the pump engine was left running to keep the solution stirred. Application was started and stopped by a distributor valve on the sprayer that was operated from the tractor. By careful adjustment of the application rates and close attention to stabilizer material volumes, the stabilizer amounts that were applied agreed well with the calculated requirements. The application rates and concentrations for each stabilizer are shown in Table 7. 
TABLE 7. Dilution and Application Rates of Field-Tested Stabilizers

\begin{tabular}{|c|c|c|c|}
\hline Stabilizer & $\begin{array}{l}\text { Recommended } \\
\text { Dilution } \\
\text { with Water } \\
\end{array}$ & $\frac{\text { Application }}{\underline{\text { Full }}}$ & $\frac{\text { Rate, (a) } \mathrm{e} / \mathrm{m}^{2}}{\underline{\text { Half }}}$ \\
\hline Aerospray-70 & $1: 10$ & 2.24 & 1.12 \\
\hline Coherex & $1: 5$ & 2.24 & 1.12 \\
\hline CPB-12 & $1: 10$ & 2.24 & 1.12 \\
\hline Dust Binder C-266 & $1: 20$ & 2.24 & 1.12 \\
\hline Dust Gard & Undiluted & 2.24 & 1.12 \\
\hline Dust Loc VMX-50 & $1: 8$ & 1.64 & 0.82 \\
\hline Hydro Mulch & 1 lb:2 gal & 3.74 & 1.87 \\
\hline$M-167$ & $1: 20$ & 1.87 & 0.94 \\
\hline Marloc & $1: 16$ & 2.81 & 1.40 \\
\hline Orzan A & $1: 3$ & 2.24 & 1.12 \\
\hline Polyco 2151 & $1: 40$ & 2.24 & 1.12 \\
\hline Sandstill II & $1: 5$ & 2.24 & 1.12 \\
\hline$S P-400$ & Undiluted & 0.42 & 0.21 \\
\hline Soil Gard & $1: 15$ & 1.22 & 0.61 \\
\hline Wa11pol 40-133 & $1: 5$ & 2.24 & 1.12 \\
\hline
\end{tabular}

(a) Full indicates the manufacturers' recormmended application rate. Half indicates one-half the manufacturers' recommended application rate.

The stabilized test plots were allowed to cure for two days, and then a survey was made of surface characteristics. Table 8 summarizes the observations made during that survey. Photographs were taken of each test plot to document the initial characteristics; additional photos are shown in Appendix A. These observations included relative surface crust hardness, approximate depth of stabilizer penetration, etc. The summary describes characteristics of the test plots that were stabilized using the full recommended amounts. For the half-strength plots, observable characteristics were similar to the corresponding full-strength plots, except that penetration was not as deep. 
In nearly all cases, the 15 stabilizers were sprayed onto the test plots with no difficulties. Minor problems were noted in the application of Soil Gard, which coagulated in the sprayer tank, pump, and nozzles, resulting in difficulties in cleaning the sprayer before the next stabilizer was applied. The sprayer system had been thoroughly cleaned before adding the Soil Gard, and previous laboratory tests with this material had not resulted in coagulation of the solution. One possible reason for this occurrence is that an adverse reaction could have occurred between the stabilizer and the water used to dilute the product. The manufacturer recommends that hard water or water with a low $\mathrm{pH}$ not be used to dilute the Soil Gard. Water from a runoff collection pond was used in the field test. Subsequent laboratory tests with water chemically similar to that used in the field test resulted in a minor degree of coagulation of the emulsion. None of the other products reacted the same way when diluted. This incident proved to be the only problem encountered during application of the chemical stabilizers. Although it did require disassembling the pump to clean the sprayer systern, the problem with the emulsion did not seriously interfere with spraying of the product. Reasonably uniform coverage was achieved with the Soil Gard.

The only other application problem was in spraying the Hydro Mulch. The hydroseeder used for spreading the mulch is designed for large-scale applications. The small size of the test plots and the difficulty of producing uniform coverage of the test plots created some problems. However, the hydroseeder is very well adapted for spraying the wood fiber mulch on larger projects where less uniform application is acceptable.

\section{SITE PROTECTION}

Once all the stabilizers were applied, a few activities were performed to protect the test site. One of these tasks was to stabilize the area surrounding the test plots where traffic had disturbed the surface. Without some form of stabilization, this loose material could easily be blown onto the surface of the test plots and interfere with the evaluation of the stabilizers. In most cases, the amount of stabilizer needed for the test plot was less than what was shipped from the manufacturer. The remainder was applied to the traveled areas in heavier amounts than on the test plots to ensure that those areas would be less susceptible to erosion. The areas treated in this way included the strips between the test plots and around the perimeter of the test area, which had been driven on during the initial site preparation and stabilizer application.

A perimeter fence was also constructed around the test area to avoid inadvertent vehicular traffic during the monitoring period. The fence consisted of a single wire strung between widely spaced steel fence posts and did not obstruct wind blowing across the pile. Nor did the fence restrict animal intrusion onto the test area, which is a natural occurrence that may affect the durability of the stabilizers. 
TABLE 8. Surface Characteristics of Stabilized Test Plots(a)

\begin{tabular}{|c|c|}
\hline Stabilizer & Observations \\
\hline Aerospray-70 & Thin hard crust \\
\hline Coherex & Thin $(\sim 0.3 \mathrm{~cm})$ soft crust \\
\hline CPB-12 & Very hard thin $(-0.6 \mathrm{~cm})$ crust \\
\hline Dust Binder C-266 & Thin and flexible \\
\hline Dust Gard & Crusted but moist and soft \\
\hline Dust Loc VMX-50 & Thin hard crust; slightly flexible \\
\hline Hydro Mulch & $\begin{array}{l}\text { Thin crust; firm but not hard; } \\
\text { crusting probably due to tackifier }\end{array}$ \\
\hline M-167 & Hard and brittle thin crust \\
\hline Marloc & Thin flexible crust \\
\hline Orzan A & $\begin{array}{l}\text { Thin }(-0.3 \mathrm{~cm}) \text { brittle crust when } \\
\text { dry but resealed when wetted }\end{array}$ \\
\hline Polyco 2151 & Thin hard crust; rather fragile \\
\hline$S P-400$ & $\begin{array}{l}\text { Thin ( } 0.3 \mathrm{~cm} \text { or less) flexible } \\
\text { crust; very tacky where heavily } \\
\text { applied (such as around weather } \\
\text { station) }\end{array}$ \\
\hline Sandstill II & $0.3 \mathrm{~cm}$ crust; softer than others \\
\hline Soil Gard & $0.3 \mathrm{~cm}$ or less; hard surface \\
\hline Wallpol 40-133 & Thicker crust $(\sim 1.3 \mathrm{~cm})$; very hard \\
\hline
\end{tabular}


The objective of the field test monitoring is to evaluate the effectiveness and durability of the stabilizers with time by visual inspection of the test plots aided by photographs taken of specific areas on each test plot. In addition, meteorological data being recorded at the field site weather station provide a chronological record of weather conditions that may contribute to the degradation or failure of the stabilizers. The evaluation procedure for this task provides qualitative information about the effectiveness and durability of the stabilizer. A more quantitative approach was not found that would provide useful data and still be cost effective.

After 1 year of monitoring at the field test site, the stabilizers have gone through a complete weather cycle; the site was visited three times. A summary of observations made in June 1983 is presented in Table 9. The stabilizers have deteriorated with time; however, some of the observed changes were caused by tailings blowing over the test area and masking the condition of the stabilizers. The climate changes during the year are summarized in Table 10. The weather during the year was typical for Gas Hills, Wyoming.

Photographs of the original stabilized surfaces were compared with photographs taken 11 months 1ater. Photographs of selected test plots after exposure to weathering are shown in Figures 15 and 16, which illustrate the most effective stabilizer and one showing considerable degradation. Additional test plot photographs are shown in Appendix A.

The chemical stabilizers 1 isted in Table 11 are grouped according to their overall effectiveness. Two PNL engineers independently examined each of the test plot surfaces. Their results were then compared to establish the overall relative effectiveness of each of the chemical stabilizers. Based primarily on visual observations, the best overall stabilizers are found in Group I; lesser effective ones, in Groups II and III. None of the stabilizers applied at onehalf the manufacturers' recommended rates of application were very effective.

As noticed from past monitoring trips, rain generally softened the surface crusts formed by the stabilizers. In some cases, such as with the watersoluble Orzan, rain may even reform the crust if it becomes damaged. However, as with the Orzan in particular, rain will tend to leach some of the materials down into the tailings below the surface, thus decreasing their effectiveness.

Even the most effective stabilizers had undergone some deterioration and erosion after 11 months of weathering. The condition of these stabilizers suggests that they would probably not be very effective much longer. Based on the 11-month observations, 1 year is considered to be the limit for even the better stabilizers to protect a tailings surface from wind erosion under the weathering conditions in Gas Hills, Wyoming. Additional monitoring is needed to further determine the limits to the effective lifetimes of the better stabilizers. 
TABLE 9. Observations of Relative Effectiveness of Chemical Stabilizers

Stabillizer

Hydro Mulch

Ful 1-strength

Helf-strength

$M-167$

Full-strength

Half-strength

Dust Loc $M M x-50$

Ful I-strength

$\stackrel{\omega}{\rho}$

Hilf-strength

20

CPQ-12

Ful I-strength

70

HIf-strength

30

Dust Gard

Full-strength

50

lalf-strength

30

Orzan A

Ful I-strength

50

HIf-strength
Orust Th Ickness,

0.2 to 0.3

0.2

Very thin

Unmeasurable

0.2 to 0.3

Unneasurable

0.2 to 0.3

0.2 to 0.3

0.2 to 0.4

0.2

$\ll .2$

Undetectable
Firm crust; moderately hard

Much less than wth ful Istrength Hydro Mulch

No apparent crust

No apparent crust

lerd but still same

flexiblitity

Some crust remaining but very fraglle

Herd crust remaining;

few scour holes

Finm but fraglle

Firm crust; harder

than most latexes

Hard crust where evident

Fragile crust where any

orzan remaining

Fragile and crumbly
Overal I

Effectiveness (a)

Large holes (up to $1 \mathrm{ft}$ depp) cut

into surface of plot

General erosion overall; holes

$\sim$ ft deep

Badly eroded; perhaps worst

stabilizer

Very poor results; nearly all

eroded away

Llght to moderate; no bad scouring

Badly eroded; hard crust on

remainder

LIHIle erosion

Mst remaining; not much scouring

Erosion but I ittle scouring; appears to be water erosion

Moderate scouring

Shallow scouring; much sand biom onto test plot

LIttle scour ing; good crust where some left
5

7

3

3

3

2

1

1

4

3 
TABLE 9. (contd)

\$ Stablilizer Oust Thickness,

Stabilizer

Sandstill ||

Ful I-strength

70

0.2 to 0.3

Holf-strength

30

0.2 to 0.3

0.2 to 0.3

Ful I-strength

Half-strength

50

20

0.2

Soll Gard

Ful I-strength

70

Holt-strength

$\omega$

Vel Ipol 40-133

Ful 1-strength

80

0.3 to 0.6

Helf-strength

$<30$

0.2 to 0.3

$\mathrm{SP}^{-400}$

$\begin{array}{rll}\text { Ful I-strength } \quad>90 & 0.2 \text { to } 0.3 & \begin{array}{l}\text { Very flexible; more I ike } \\ \text { a complete membrane }\end{array}\end{array}$

Half-strength

40

0.2

Dust Binder C-266

Ful I-strength
Crust Hordness

Surface degraded but some remeining underneath

Fraglle

Fraglle; easlly broken

Fragile and very spotted

Hardest but fraglle

Remeinder very sott

Very hard crust; appears

very durable (best

stabllizer)

Hard but same flexibllity

Thin and very flexible

Very hard where left averal I

Ef fect I veness ${ }^{(\theta)}$

3

6

1

Erosion all over plot; poorest stabilizer

No mejor ercsion; same small scaur marks

Some shal la scauring but stlll in falr condition

Not much ercsion yet but showing

some signs of deterioration

Spotted deterioration and scauring;

3

patches of meterlal blowing away

Large-scale erosion of test pl ot;

lots of drifting sand on plot 
TABLE 9. (contd)

\begin{tabular}{|c|c|c|c|c|c|}
\hline Stab il izer & $\begin{array}{l}\text { of Stab il Izer } \\
\text { Rerraining } \\
\end{array}$ & $\begin{array}{l}\text { Crust Thidkness, } \\
\mathrm{cm}\end{array}$ & Crust Hardness & Surface Erasion & $\begin{array}{c}\text { Qveral I } \\
\text { Effect iveness (a) }\end{array}$ \\
\hline lal f-strength & 20 & 0.2 & $\begin{array}{l}\text { Finm crust where } \\
\text { renaining }\end{array}$ & Averal l erosion of plot & 2 \\
\hline \multicolumn{6}{|l|}{ Aerospray-70 } \\
\hline Ful I-strength & 60 & 0.2 to 0.3 & $\begin{array}{l}\text { Hard crust where } \\
\text { remelning }\end{array}$ & $\begin{array}{l}\text { Shal law general scauring; In fairly } \\
\text { good shape }\end{array}$ & 5 \\
\hline Helf $\rightarrow$ strength & 20 & 0.2 to 0.3 & $\begin{array}{l}\text { lard crust; less remain- } \\
\text { ing than with full } \\
\text { strength }\end{array}$ & Shal la but no severe eros ion & 2 \\
\hline \multicolumn{6}{|l|}{ Marloc } \\
\hline Ful I-strength & (19) & 0.3 & Hard and durable crust & $\begin{array}{l}\text { Shal low scauring al l over pl ot; } \\
\text { on ly smell patches of material left }\end{array}$ & 4 \\
\hline Helf-strength & 25 & 0.2 to 0.3 & Flrm but fraglle crust & No deep scaring but overall & 3 \\
\hline 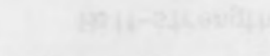 & ant & $\sqrt{4} 3$ & 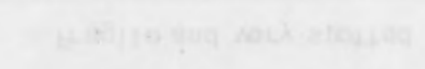 & deterioration & 5 \\
\hline \multicolumn{6}{|l|}{ Polyco 2151} \\
\hline Ful I-strength & $<40$ & 0.2 to 0.3 & Hard fragile crust & $\begin{array}{l}\text { Same deep scauring but lots of sand } \\
\text { drifts from arts ide area }\end{array}$ & 3 \\
\hline Holf-strength & 10 & 0.2 & Soft tragile crust & $\begin{array}{l}\text { Overall wind erosion; stabllizer } \\
\text { nearly gone }\end{array}$ & 2 \\
\hline
\end{tabular}

(a) Overall ef fect lveness rating: 0-lowest to 10-highest. 
TABLE 10. Summary of Weather Data from the Field Test Site for September 1982 through June 1983

\begin{tabular}{|c|c|c|c|c|c|c|c|c|}
\hline \multirow[b]{2}{*}{ Month } & \multirow{2}{*}{$\begin{array}{c}\text { Averaye } \\
\text { Temperature, }{ }^{\circ} \mathrm{C}\end{array}$} & \multirow{2}{*}{$\begin{array}{c}\text { High } \\
\text { Temperature, }{ }^{\circ} \mathrm{C} \\
\end{array}$} & \multirow{2}{*}{$\begin{array}{l}\text { Average High } \\
\text { Temperature, }{ }^{\circ} \mathrm{C}\end{array}$} & \multirow{2}{*}{$\begin{array}{c}\text { Low } \\
\text { Temperature, }{ }^{\circ} \mathrm{C}\end{array}$} & \multirow{2}{*}{$\begin{array}{l}\text { Averoge Low } \\
\text { Temperature, }{ }^{\circ} \mathrm{C}\end{array}$} & \multirow{2}{*}{$\begin{array}{c}\text { Total } \\
\text { Precipitation, am } \\
\end{array}$} & \multicolumn{2}{|c|}{ Meximum Precipitation } \\
\hline & & & & & & & Amount, cm & Date \\
\hline September & 13.7 & 30.8 & 20.0 & -1.5 & 7.6 & 5.61 & 1.98 & $9 / 30 / 82$ \\
\hline october & 6.2 & 20.4 & 12.0 & -7.7 & 0.9 & 4.14 & 2.01 & $10 / 5 / 82$ \\
\hline Novenber & -0.9 & 12.9 & 4.1 & -17.2 & -5.9 & 0.81 & 0.30 & $11 / 13 / 82$ \\
\hline December & -5.1 & 6.1 & -9.5 & -21.4 & -9.5 & 1.85 & 0.84 & $12 / 1 / 32$ \\
\hline January & -1.6 & 8.8 & 3.0 & -13.6 & -6.1 & 0.71 & 0.69 & $1 / 28 / 83$ \\
\hline Fobruary & -2.6 & 8.5 & 1.3 & -18.7 & -7.0 & 0.64 & 0.33 & $2 / 14 / 83$ \\
\hline March & 0.7 & 15.3 & 5.4 & -11.9 & -3.5 & 1.07 & 0.30 & $3 / 25 / 83$ \\
\hline Aorll & 2.2 & 18.7 & 7.2 & -13.6 & -2.5 & 1.98 & 0.86 & $4 / 3 / 83$ \\
\hline May & 8.3 & 25.8 & 14.1 & -8.6 & 2.9 & 2.36 & 0.56 & $5 / 30 / 83$ \\
\hline June & 16.1 & 32.1 & 23.1 & 1.7 & 9.4 & 3.20 & 1.68 & $6 / 13 / 83$ \\
\hline
\end{tabular}




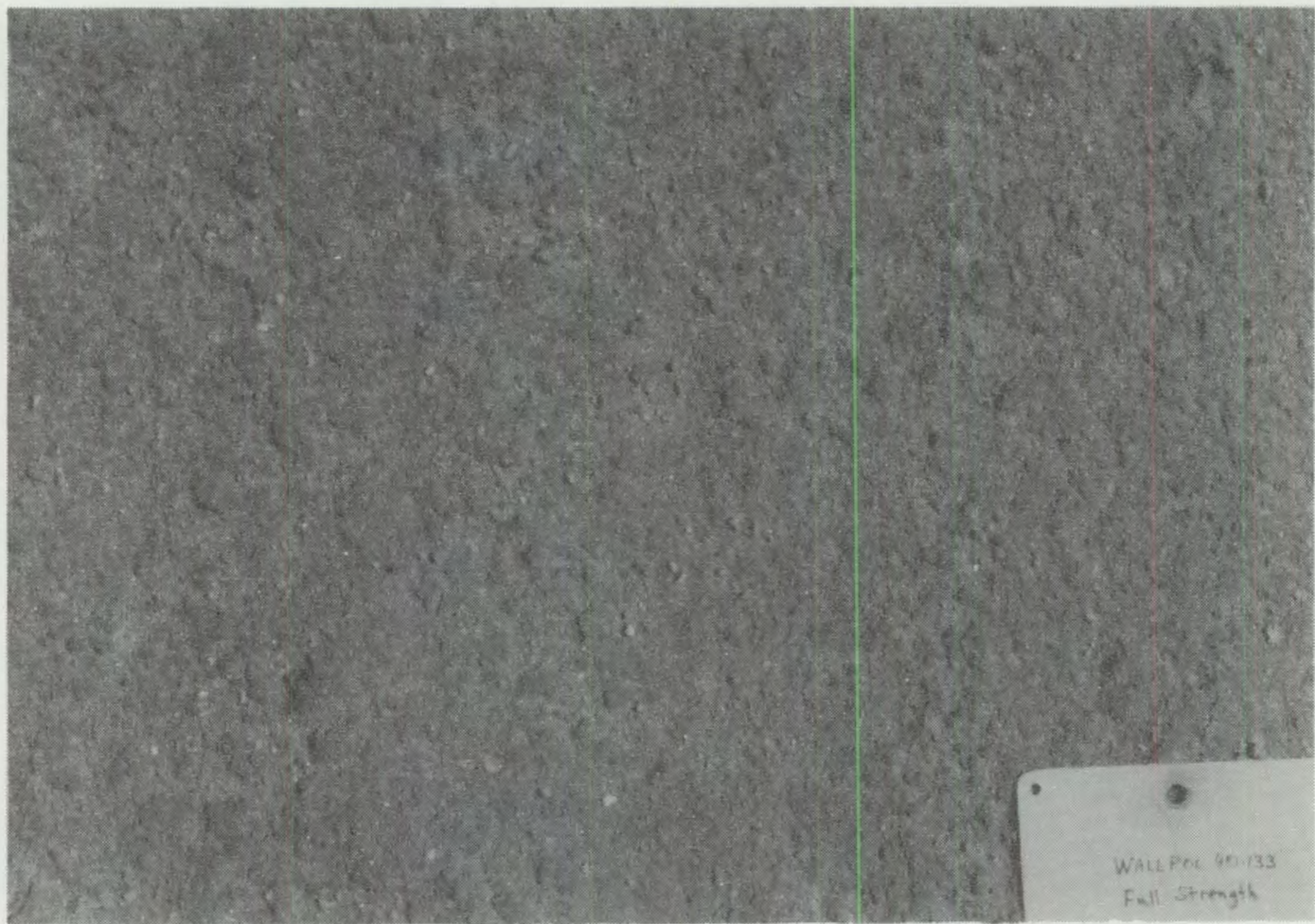

FIGURE 15. Test Plot Surface Stabilized with Wallpol 40-133 After 11 Months of Weathering (minor amount of surface erosion)

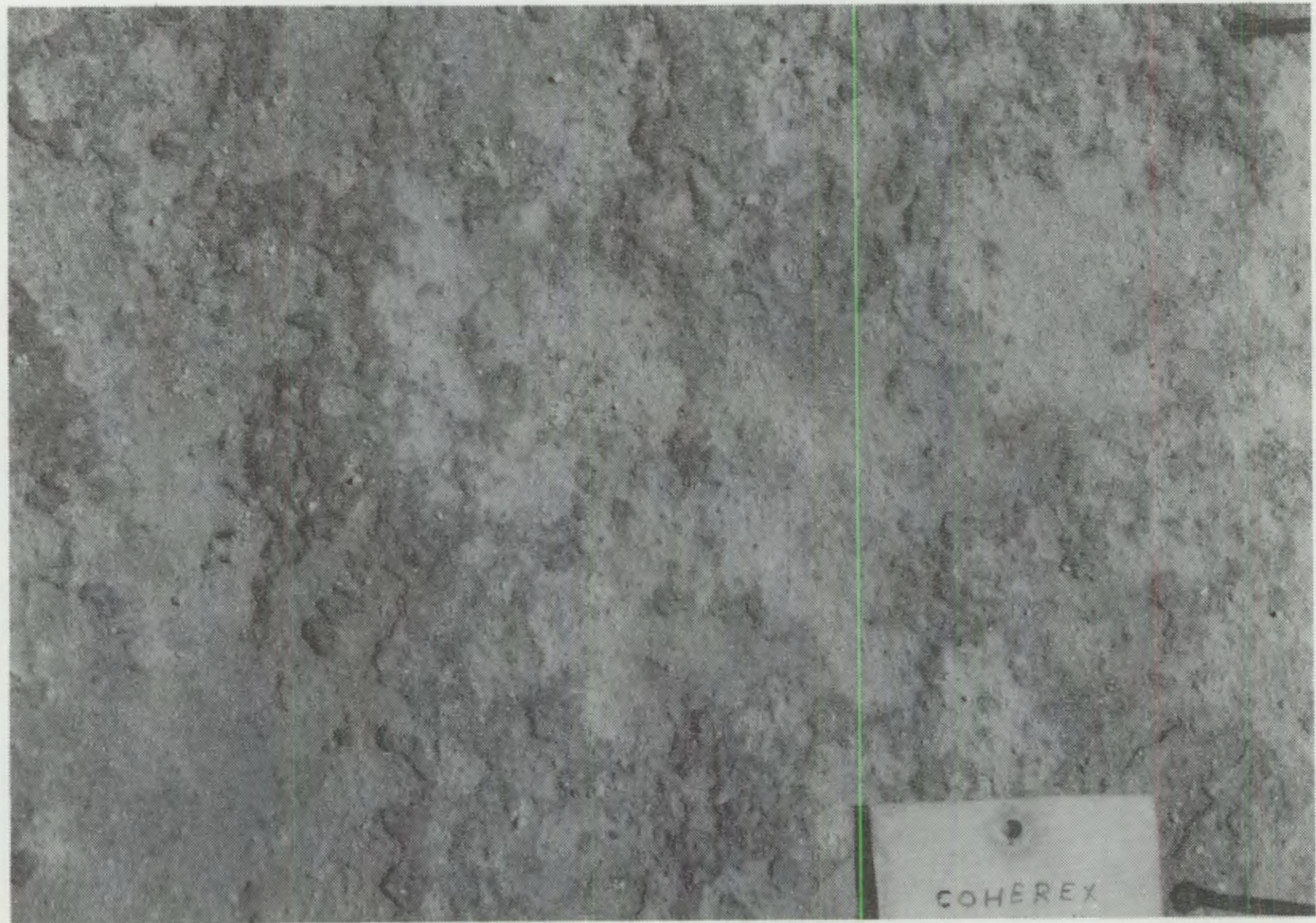

FIGURE 16. Test Plot Surface Stabilized with Coherex After 11 Months of Weathering (severe surface erosion) 
TABLE 11. Chemical Stabilizers Grouped by Relative Effectiveness After 1 Year of Weathering

\begin{tabular}{|c|c|c|c|}
\hline roup & Stabilizer & Composition & Relative Effect \\
\hline I & $\begin{array}{l}\text { Wal1 pol } 40-133 \\
\text { SP-400 } \\
\text { CPB-12 }\end{array}$ & $\begin{array}{l}\text { Vinyl acetate/acrylic } \\
\text { Latex emulsion } \\
\text { Acrylic emulsion with condi- } \\
\text { tioners }\end{array}$ & $7-10$ (good \\
\hline II & $\begin{array}{l}\text { Sandstill II } \\
\text { Soil Gard } \\
\text { Dust Loc VMX-50 } \\
\text { Dust Gard } \\
\text { Aerospray-70 } \\
\text { Orzan A } \\
\text { Coherex } \\
\text { Marloc }\end{array}$ & $\begin{array}{l}\text { Petroleum resins/surfactant } \\
\text { Styrene butadiene } \\
\text { Acrylic latex } \\
\text { MgCl brine } \\
\text { Polyvinyl acetate } \\
\text { Ammonium lignin sulfonate } \\
\text { Petroleum oils and resins/ } \\
\text { surfactant } \\
\text { Polyvinyl acetate }\end{array}$ & 4-6 (fair) \\
\hline III & $\begin{array}{l}\text { Hydro Mulch } \\
\text { Dust Binder C-266 } \\
\text { Polyco } 2151 \\
\text { M-167 }\end{array}$ & $\begin{array}{l}\text { Wood fiber mulch } \\
\text { Synthetic polymer emulsion } \\
\text { Vinyl acetate/acrylic } \\
\text { Latex, surfactant, propylene } \\
\text { glycol }\end{array}$ & $0-3$ (poor) \\
\hline
\end{tabular}

Weather data are recorded continually by a weather station at the test site. A summary of temperature and rainfall data is shown in Table 10 for the period from the beginning of September 1982, when the stabilizers were applied, to the end of June 1983, the last full month of data collected at the time of this report. A complete table of precipitation data for this time period is presented in Table B.1 of Appendix B. The data used to construct the wind roses presented in Figures 17 and 18 are given in Tables B.2 through B.10.

Figure 17 is a wind rose of wind speed and time data collected during the September 1982 through June 1983 test period. The wind rose shows the percent of time that wind was blowing from any particular direction across the test plot. Figure 18 is a wind rose that represents the erosion potential of the wind. Data shown here are adjusted by the "cube" of the wind speed $\left(V^{3}\right)$, giving a percent of the erosion potential of the winds distributed by direction. In doing so, the wind rose more accurately represents the severity of the wind as it may affect the erosion of the tailings. In general, soil erosion studies have shown that the horizontal flux of sand, partigularly for larger particles, is proportional to the cube of the velocity. 2 ) Results of this method indicate the fraction of time that the wind was blowing from a particular direction but weights the higher velocity winds by a higher factor since it is wind velocities above $\rightarrow 9 \mathrm{~m} / \mathrm{s}(20 \mathrm{mph})$ that contribute most to tailings erosion. Results indicate that the southwest is the very predominant prevailing wind direction, particularly for stronger, erosion-causing winds. 


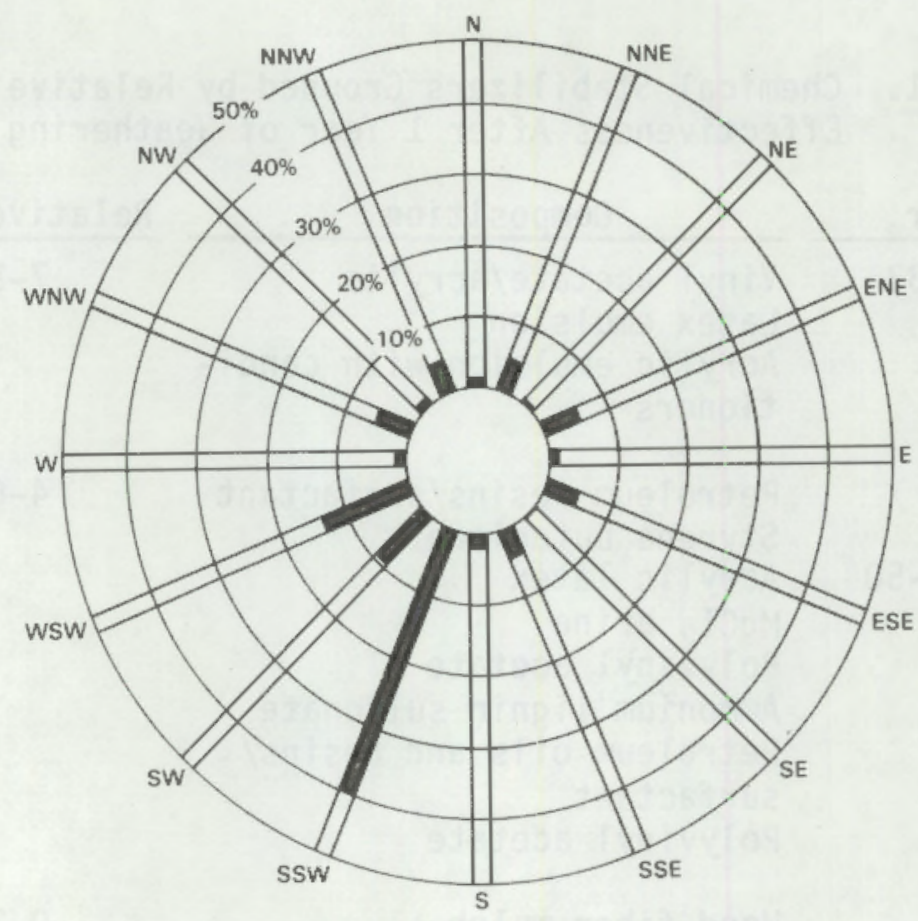

FIGURE 17. Wind Rose Using Wind Velocity and Direction Data Collected at the FAP Field Test Site from September 1982 through June 1983

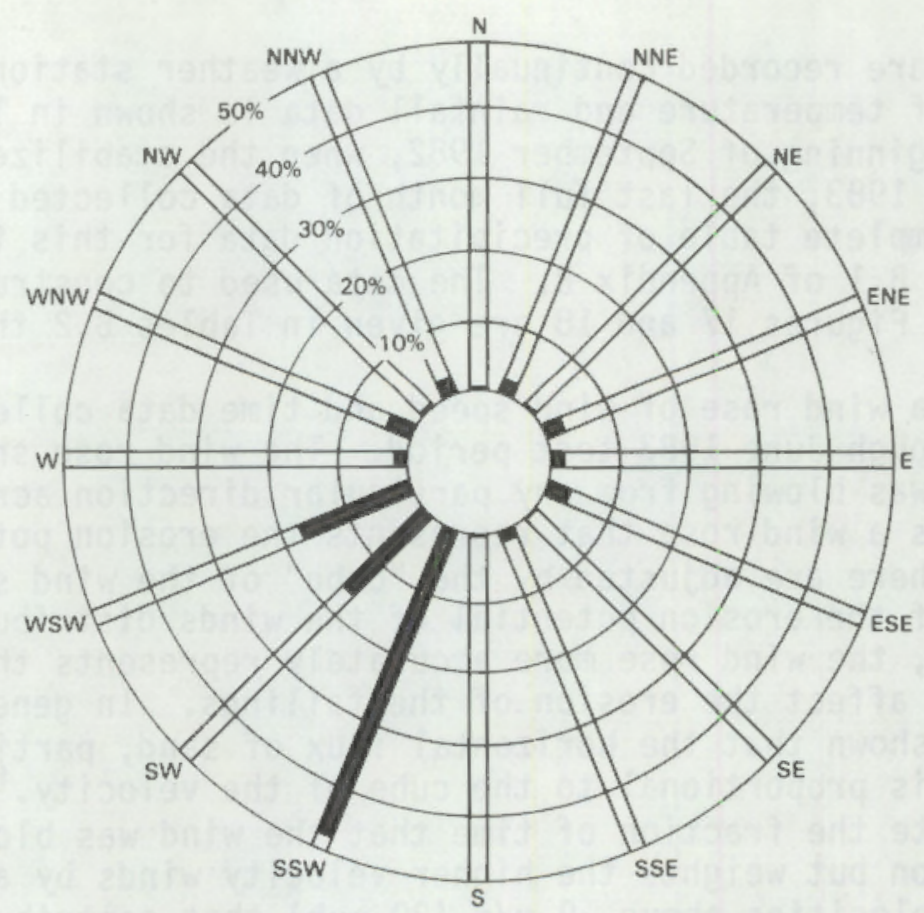

FIGURE 18. Wind Rose Using (Wind Velocity) ${ }^{3}$ and Direction Data Collected at the FAP Field Test Site from September 1982 through June 1983 
The winter months of November, December, and January tend to have the strongest winds; speeds are frequently in excess of $18 \mathrm{~m} / \mathrm{s}(40 \mathrm{mph})$. The highest velocity recorded for the test site was $22.4 \mathrm{~m} / \mathrm{s}$ (50 mph) on January 8 , 1983.

Because of the long interval between monitoring trips, it is difficult to correlate erosion of the stabilized test plots with specific weather events. However, it was observed that:

- Rain generally tended to accelerate the deterioration of the stabilizers.

- Erosion of the tailings pile was visible at wind speeds above $\sim 9 \mathrm{~m} / \mathrm{s}$, but a majority of the blowing material appeared to be coming from the surrounding area of the tailings pile rather than from the test plots.

- The windiest period is during the winter months, and there was generally not enough snow cover to fully protect the tailings pile from wind erosion.

- Exposure of the stabilized surfaces to ultraviolet light from the sun contributed to the degradation of the stabilizers. Such degradation was not discernible from other factors that also contributed to erosion but was shown to influence the durability of laboratory test specimens. 

The cost of stabilizing uranium mill tailings will vary greatly depending on the location, size of tailings pile, and type of stabilizer selected for each site. An approximation of these costs is presented below based on the installed costs of this field test. A more detailed analysis of stabilization costs will be presented in the final project report.

The application costs incurred during the field test are summarized in Table 12. PNL costs associated with site preparation, stabilizer preparation, etc., are not included. The one variable expense was the cost of the stabilizers. These costs are shown as the delivered cost of each stabilizer to the FAP mill. Other costs such as labor and equipment were constant for each test plot. PNL labor was estimated at $\$ 50$ per test plot, and equipment costs (tractor and sprayer costs) were $\$ 38$ per test plot.

The costs to chemically stabilize the test plots ranged from $\$ 92 \cdot$ to $\$ 124$ per test plot using the full recommended application rate. These figures correspond to a cost of $\$ 8,400$ to $\$ 11,300 / \mathrm{ha}(\$ 3,400$ to $\$ 4,600 /$ acre $)$. The labor and equipment costs for the field test are higher than would be expected for a large-scale application (also shown in Table 12).

In 1982, FAP personnel stabilized a large area of tailings with Orzan C. Two operators with a 10,000-gal water truck and pump applied 1 to 2 tank loads of the diluted stabilizer to a tailings pile during an 8-h shift. A 10,000-gal tank of the material, applied according to the manufacturer's recommendations, would cover an area of 1.67 ha (4.13 acres). The estimated costs of the truck and two operators was $\$ 66 / \mathrm{h}$, giving a labor and equipment charge of $\$ 158$ to $\$ 316 /$ ha $(\$ 64$ to $\$ 128 /$ acre). The estimated cost of a large-scale stabilization effort based on these more realistic labor and equipment charges ranges from $\$ 680$ to $\$ 3,600 /$ ha $($ Table 12 ).

Most of the stabilizers tested were comparably effective for the first several months following application, but only those rated "good" in Table 11 were still effective after 1 year. The more expensive stabilizers tended to last the longest. However, a mill operator may find it more cost effective to apply one of the less expensive but less durable stabilizers more frequently than to apply one of the longer lasting but more expensive materials. Such a choice would be a function of several factors, including: stabilizer cost, stabilizer availability, mill location, and other site-specific factors. 
TABLE 12. Application Costs for 1982 Field Test and for a Large-Scale Stabilization

\begin{tabular}{|c|c|c|c|}
\hline Chemical Stabilizer & $\begin{array}{c}\text { Materjal } \\
\text { Costs, }\end{array}$ & $\begin{array}{c}\text { Field Test } \\
\text { Costs, } \\
\end{array}$ & $\begin{array}{l}\text { Large-Scale } \\
\text { Stabiljzation } \\
\text { Costs, }(\mathrm{c}) \quad \$ / \text { ha } \\
\end{array}$ \\
\hline Aerospray-70 & 3,280 & 11,300 & 3,600 \\
\hline$S P-400$ & 3,170 & 11,200 & 3,490 \\
\hline Oust Loc VMX-50 & 2,790 & 10,800 & 3,110 \\
\hline Wallpol 40-133 & 2,690 & 10,700 & 3,010 \\
\hline Oust Gard & 2,260 & 10,300 & 2,580 \\
\hline $\mathrm{CPB}-12$ & 1,980 & 10,000 & 2,300 \\
\hline Marloc & 1,910 & 9,900 & 2,230 \\
\hline Dust Binder C-266 & 1,880 & 9,800 & 2,200 \\
\hline Sandsti11 II & 1,630 & 9,600 & 1,950 \\
\hline$M-167$ & 1,580 & 9,600 & 1,900 \\
\hline Soil Gard & 1,350 & 9,300 & 1,670 \\
\hline Coherex & 1,250 & 9,200 & 1,570 \\
\hline Hydro Mulch & 810 & 8,800 & 1,130 \\
\hline Polyco 2151 & 480 & 8,500 & 800 \\
\hline Orzan A & 360 & 8,400 & 680 \\
\hline
\end{tabular}

(a) Stabilizer costs are based on delivery to location in central Wyoming; costs will vary with location.

(b) Includes PNL labor at $\$ 50 /$ test plot and equipment costs at $\$ 38 /$ test plot, which represents a total cost of $\$ 7,300 / \mathrm{ha}$.

(c) Includes expected labor and equipment charges of $\$ 316 /$ ha based on FAP estimate of similar project using two operators and 10,000-gal spray truck. 


\section{REFERENCES}

1. Li, C. T., M. R. Elmore, and J. N. Hartley. 1983. A Review of Fugitive Dust Control for Uranium Mill Tailings. NUREG/CR-2856, PNL-4360, Pacific Northwest Laboratory, Richland, Washington.

2. Sehme1, G. A. 1980. "Particle Resuspension: A Review." Envir. Intern. $4: 107-127$. 

APPENDIX A

TEST PLOT PHOTOGRAPHS 


\author{
APPENDIX A
}

\title{
TEST PLOT PHOTOGRAPHS
}

This appendix consists of photographs of test plots stabilized with each of the 15 stabilizers investigated in this field test. A $0.5 \times 0.5-m$ area as of August 1982, the same area as of June 1983, and a view of the test plot are shown for each stabilizer. The figures in this appendix are arranged in order of relative effectiveness. 


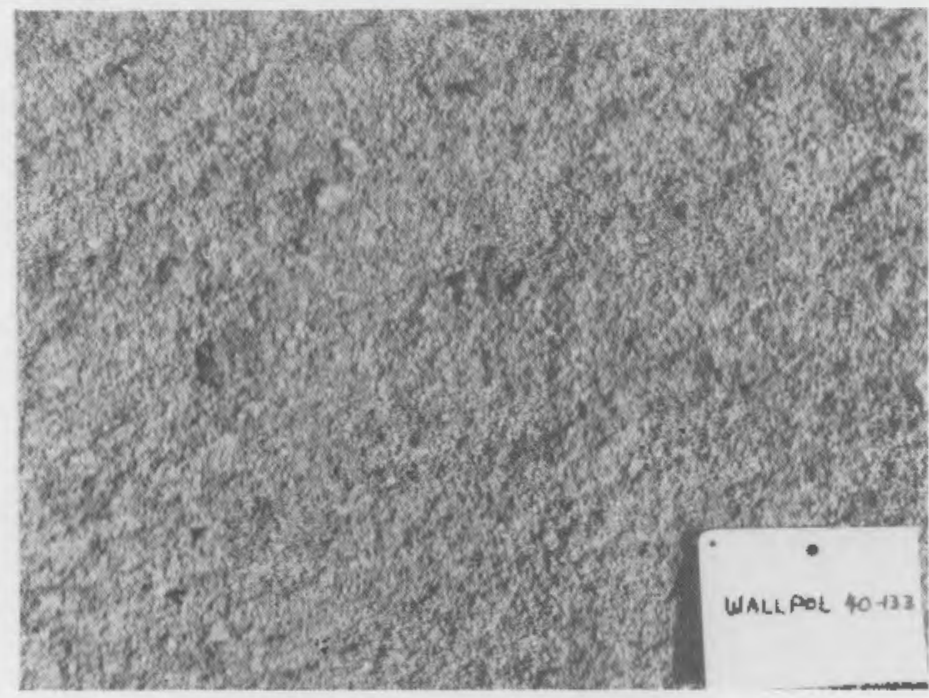

AUGUST $1982(0.5-\mathrm{m} \times 0.5-\mathrm{m}$ AREA)

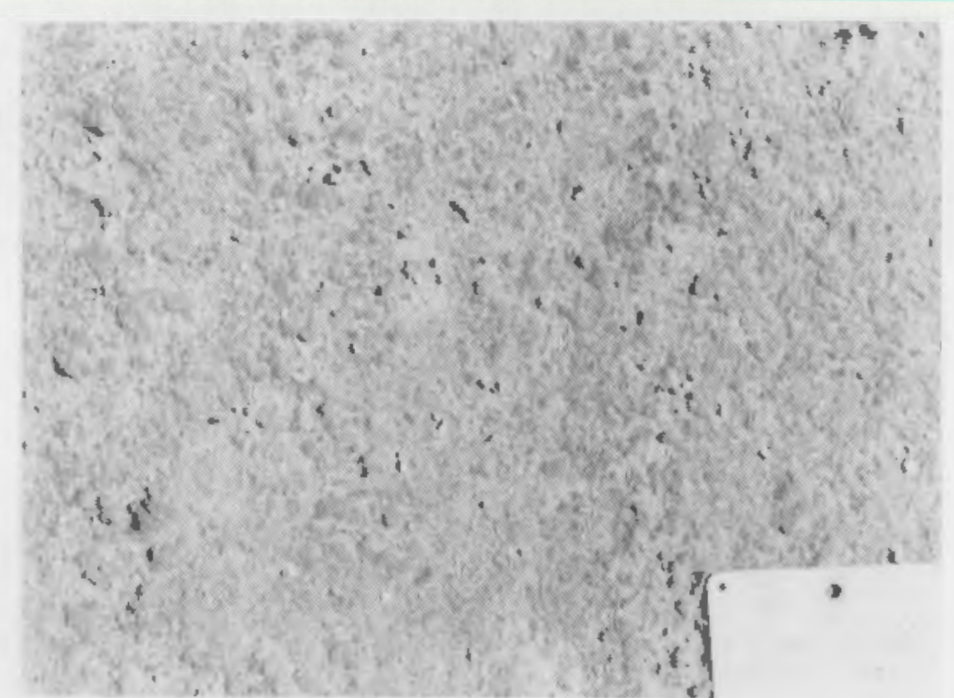

JUNE $1983(0.5-\mathrm{m} \times 0.5-\mathrm{m}$ AREA)

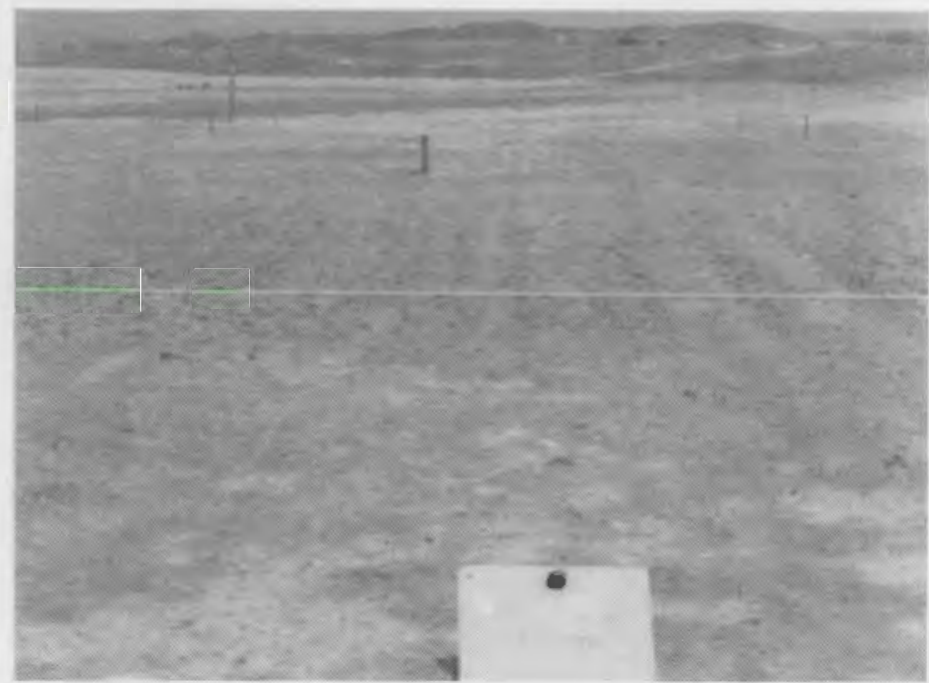

JUNE 1983 (OVERVIEW)

FIGURE A.1. Test Plot Stabilized with Wallpol 40-133 


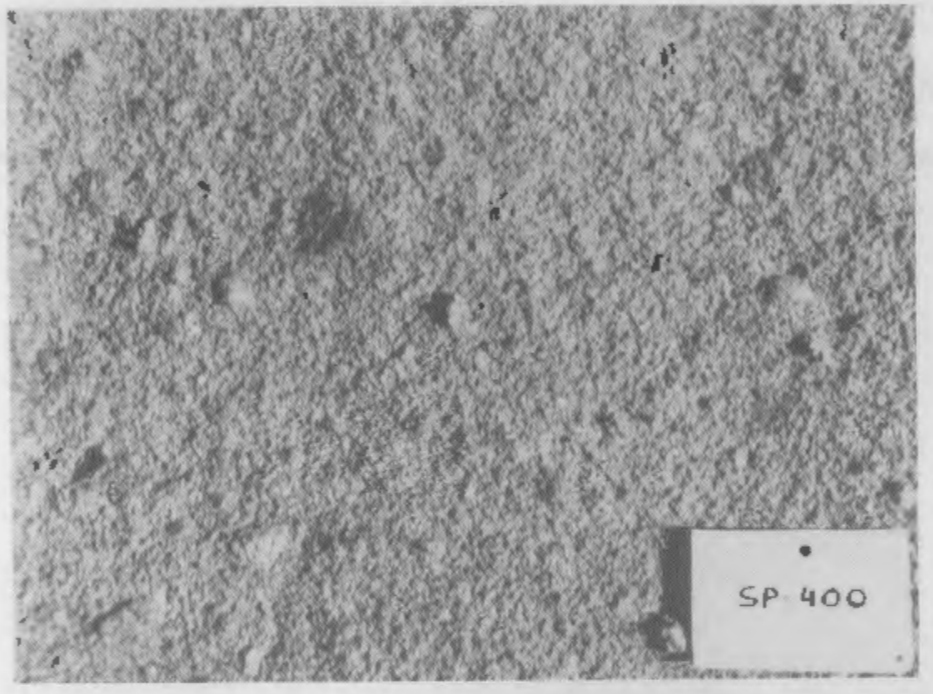

AUGUST $1982(0.5-\mathrm{m} \times 0.5-\mathrm{m}$ AREA)

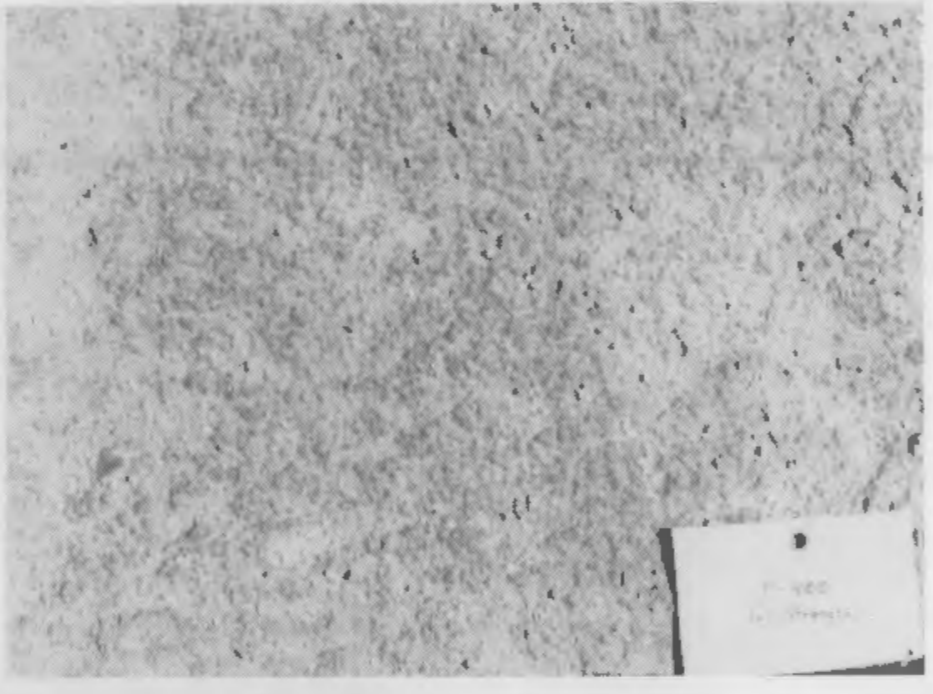

JUNE $1983(0.5-\mathrm{m} \times 0.5-\mathrm{m}$ AREA)

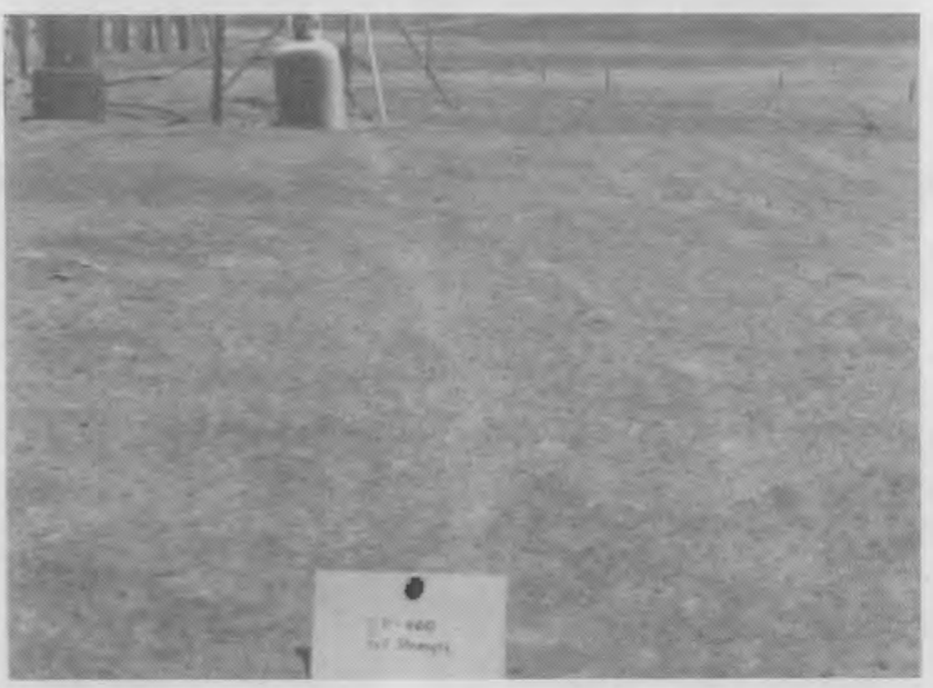

JUNE 1983 (OVERVIEW)

FIGURE A.2. Test Plot Stabilized with SP-400 


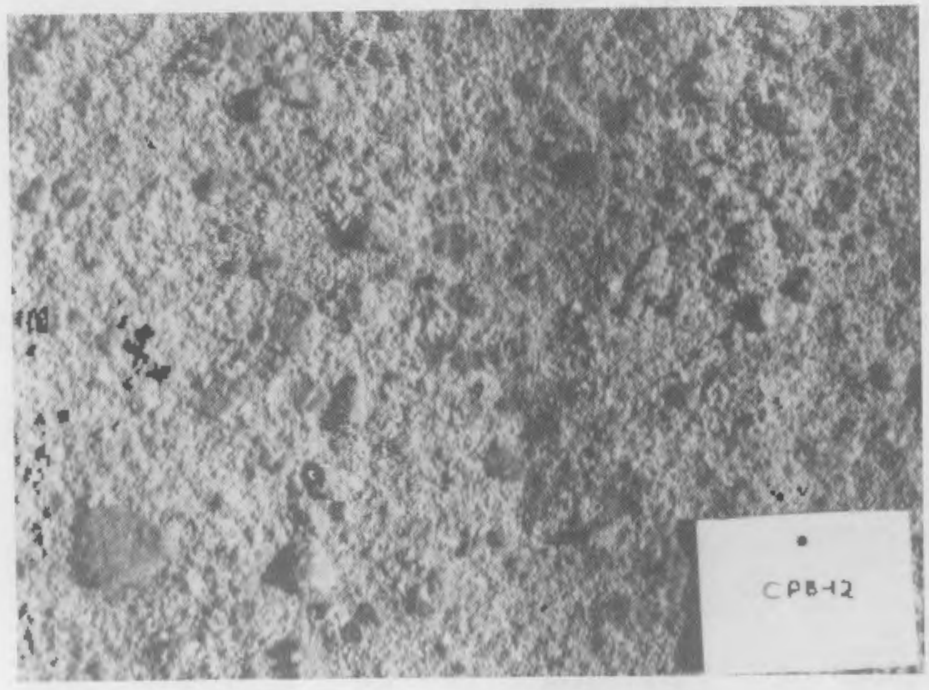

AUGUST $1982(0.5-\mathrm{m} \times 0.5-\mathrm{m}$ AREA)

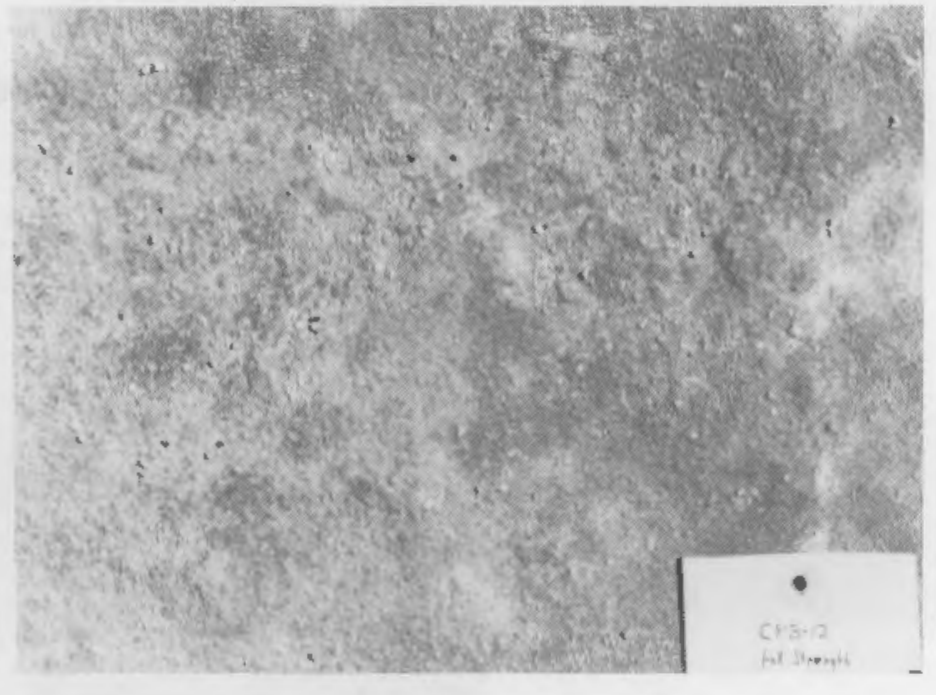

JUNE $1983(0.5-\mathrm{m} \times$ 0.5-m AREA)

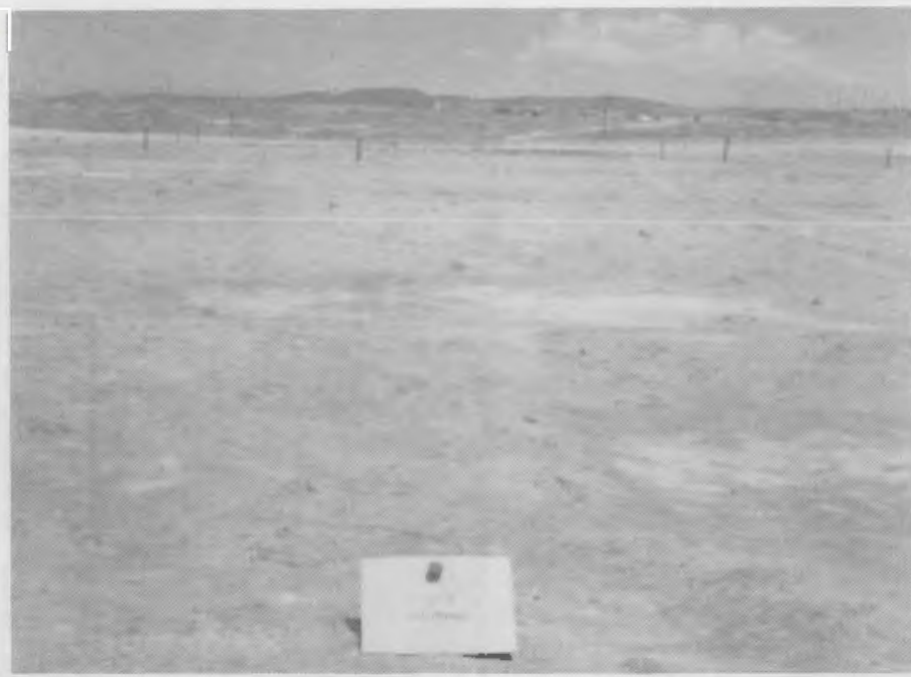

JUNE 1983 (OVERVIEW)

FIGURE A.3. Test Plot Stabilized with CPB-12 


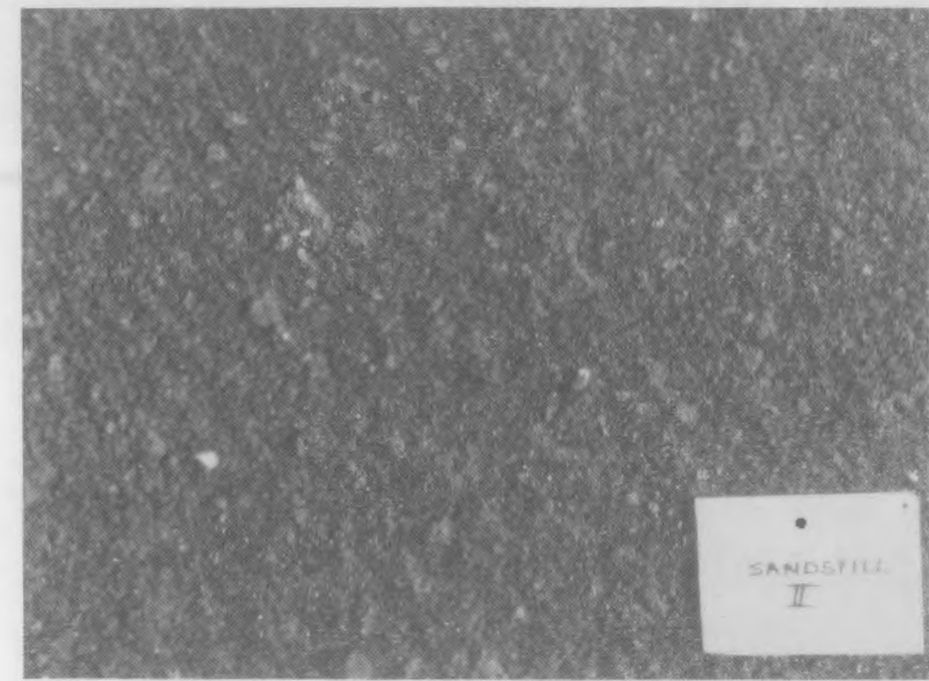

AUGUST $1982(0.5-\mathrm{m} \times 0.5-\mathrm{m}$ AREA)

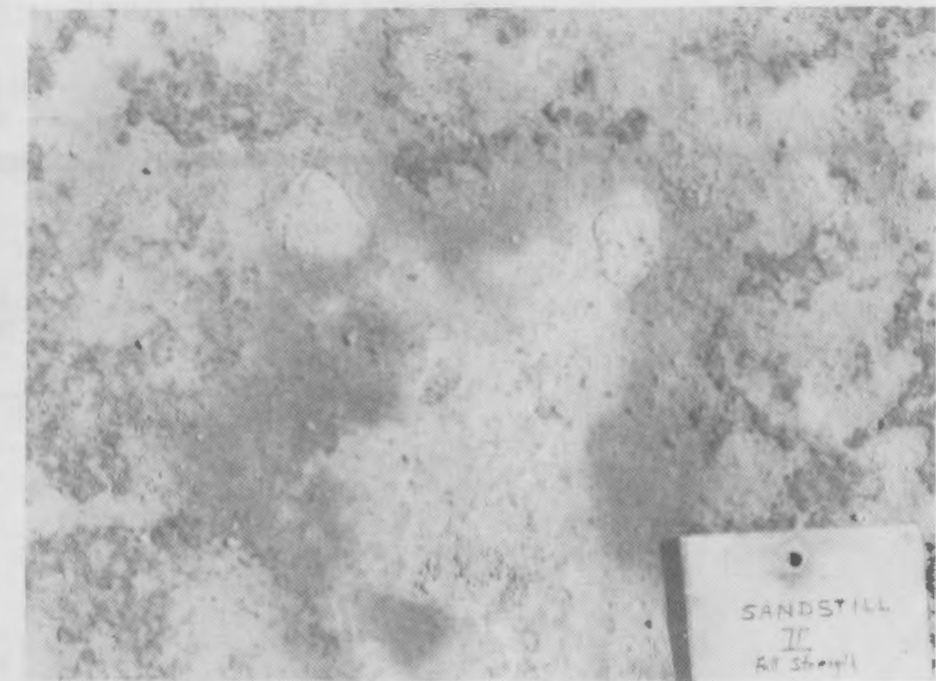

JUNE $1983(0.5-\mathrm{m} \times$ 0.5-m AREA)

ir

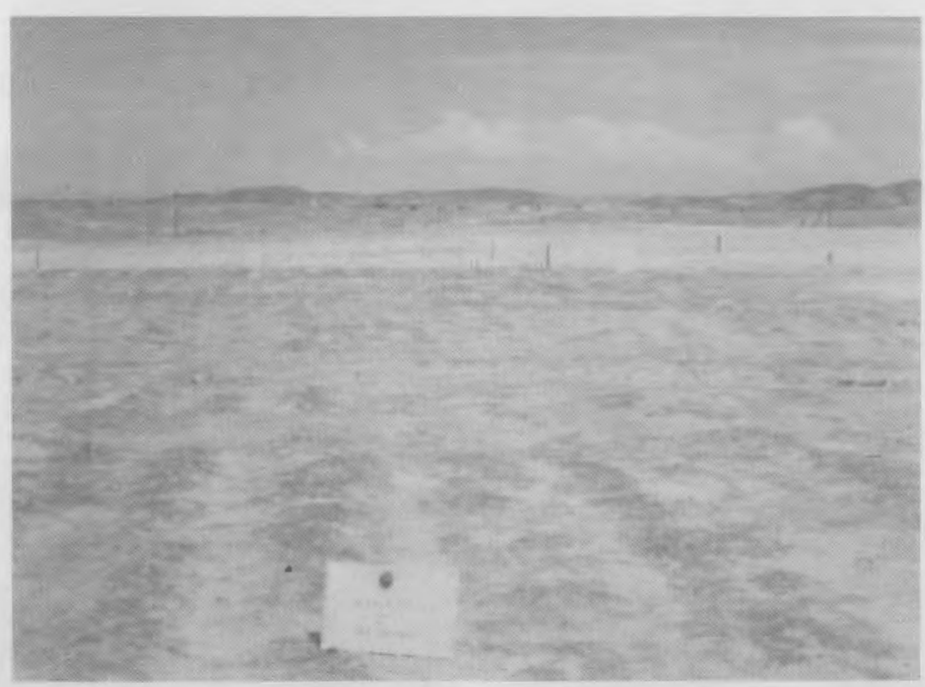

JUNE 1983 (OVERVIEW)

FIGURE A.4. Test Plot Stabilized with Sandstill II 


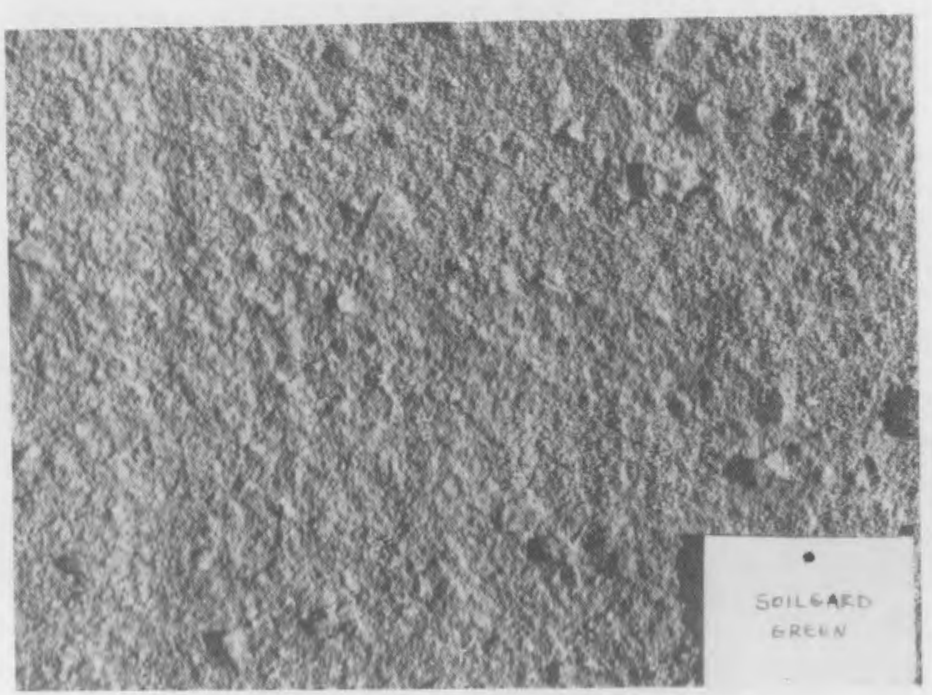

AUGUST $1982(0.5-\mathrm{m} \times 0.5-\mathrm{m}$ AREA)

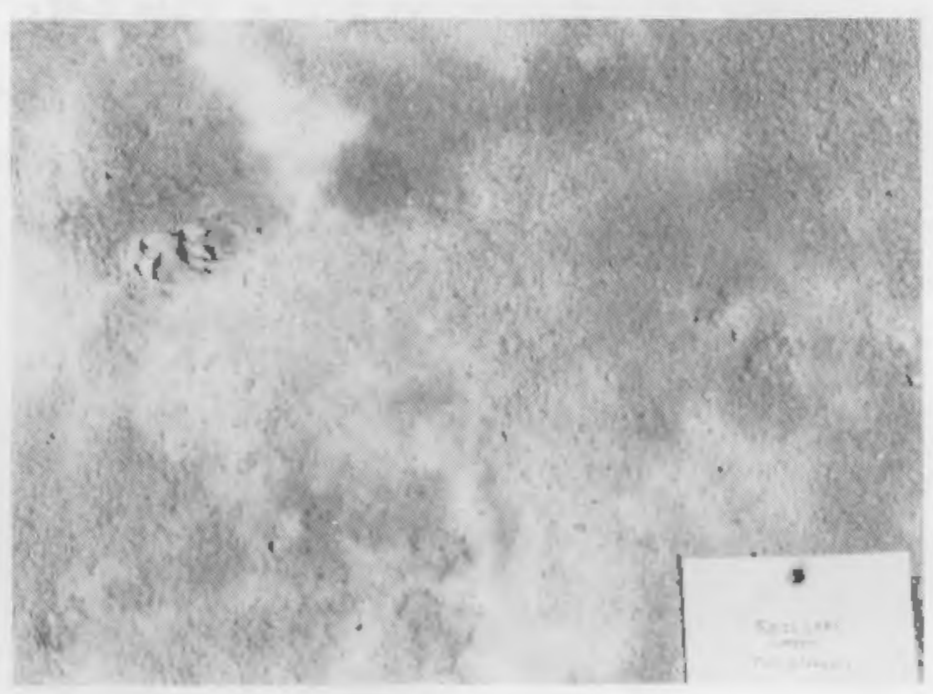

JUNE 1983 (0.5-m $\times$ 0.5-m AREA)

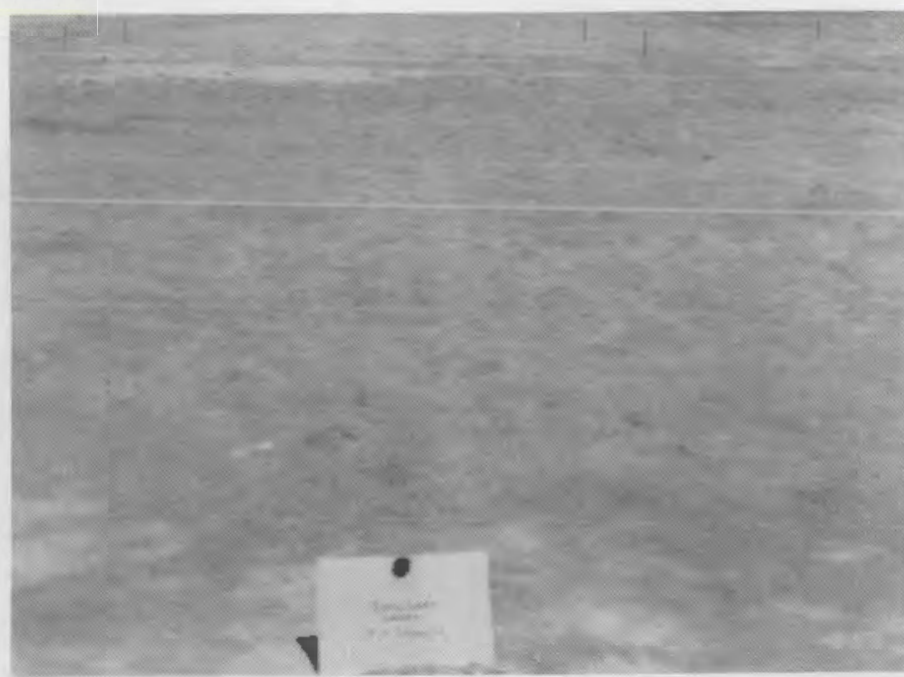

JUNE 1983 (OVERVIEW)

FIGURE A.5. Test Plot Stabilized with Soil Gard 


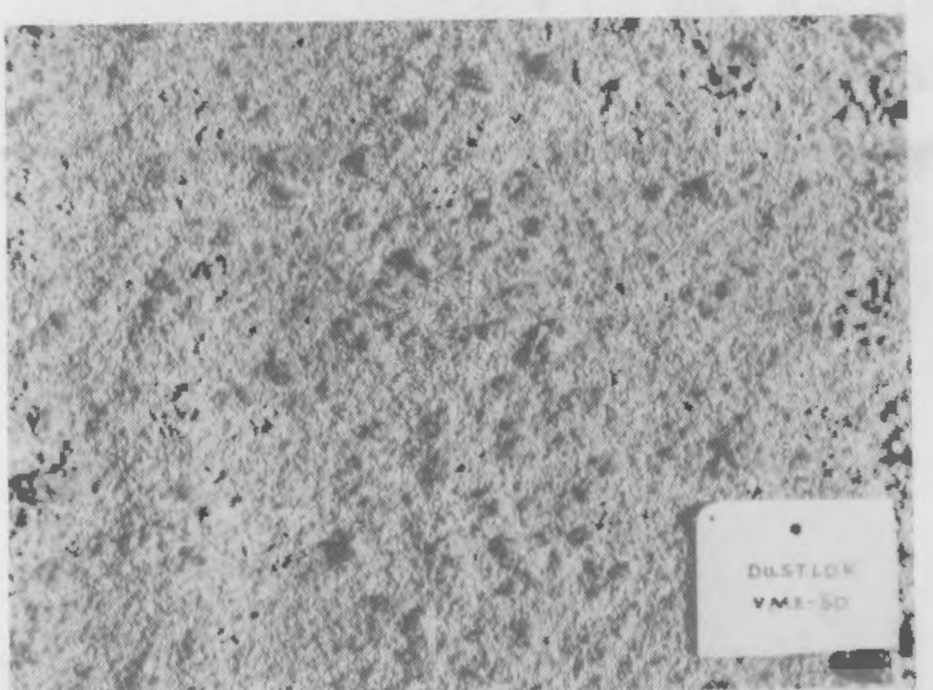

AUGUST $1982(0.5-\mathrm{m} \times 0.5-\mathrm{m}$ AREA)

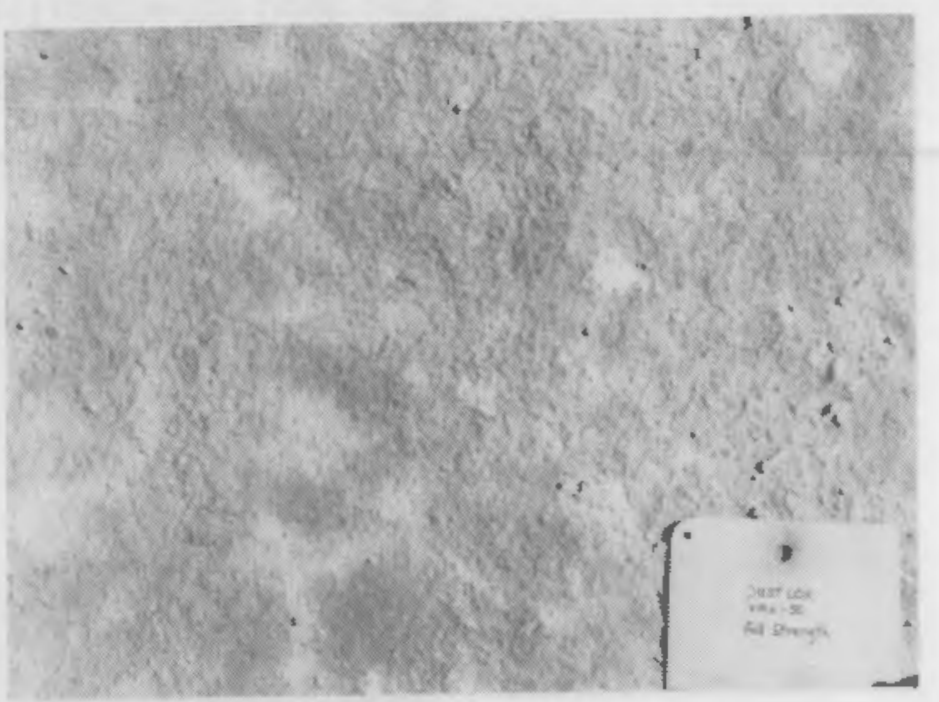

JUNE $1983(0.5-\mathrm{m} \times 0.5-\mathrm{m}$ AREA)

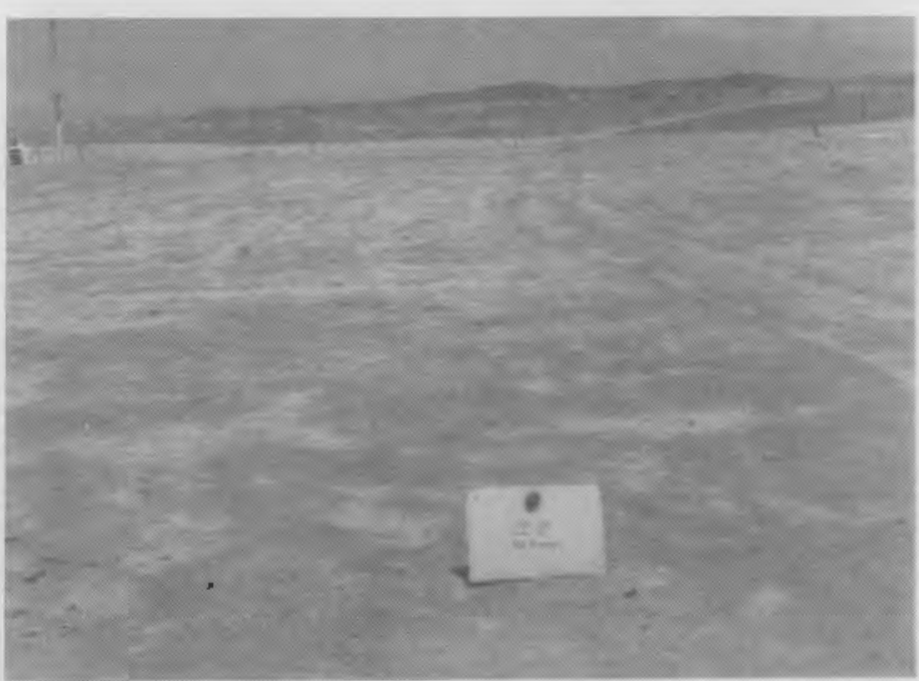

JUNE 1983 (OVERVIEW)

FIGURE A.6. Test Plot Stabilized with Dust Loc VMX-50 


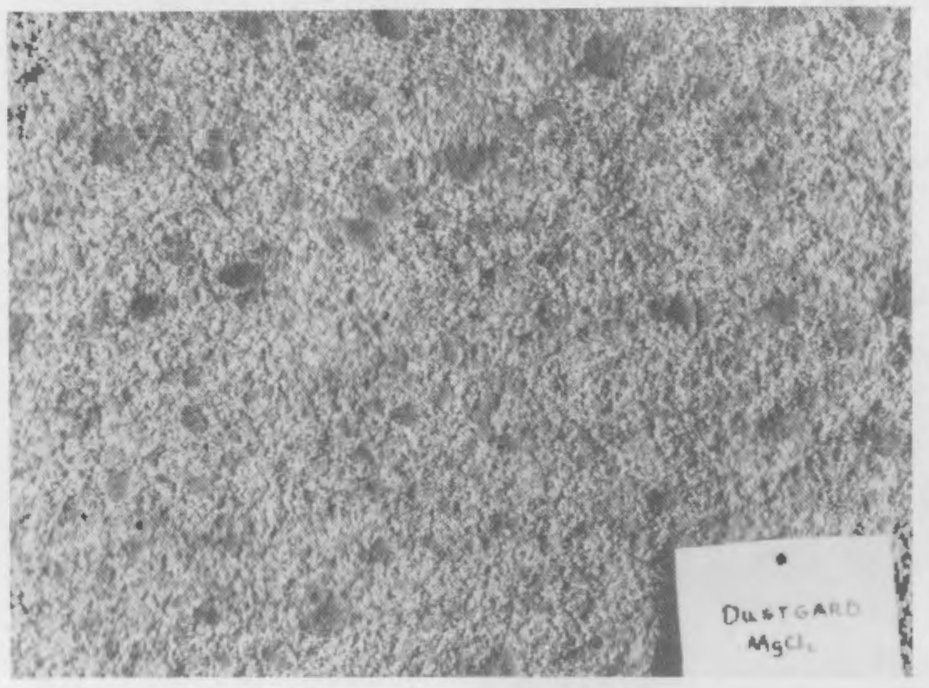

AUGUST $1982(0.5-\mathrm{m} \times 0.5-\mathrm{m}$ AREA)

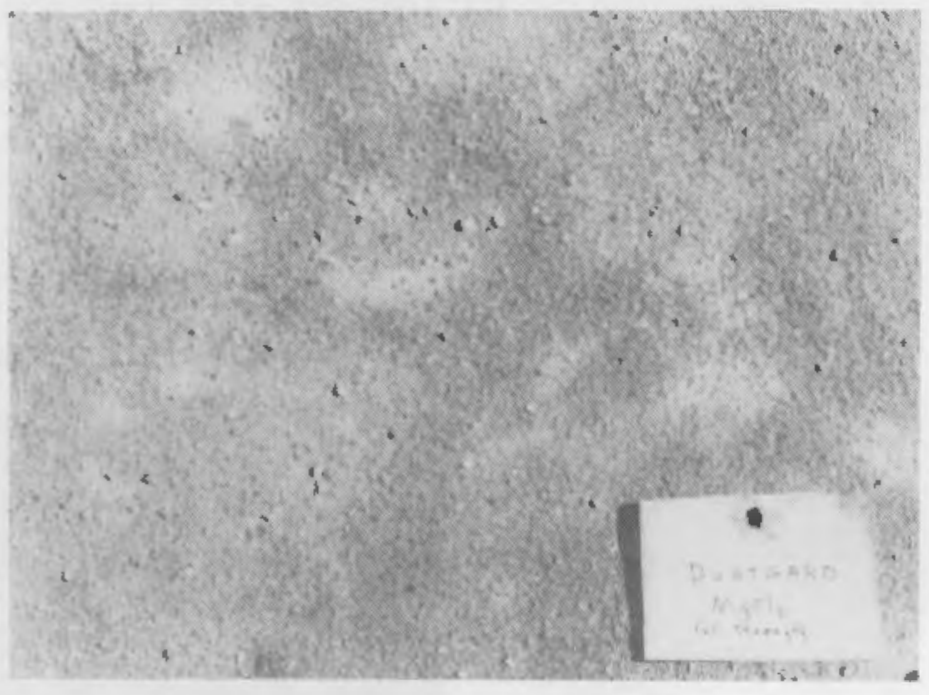

JUNE $1983(0.5-\mathrm{m} \times 0.5-\mathrm{m}$ AREA)

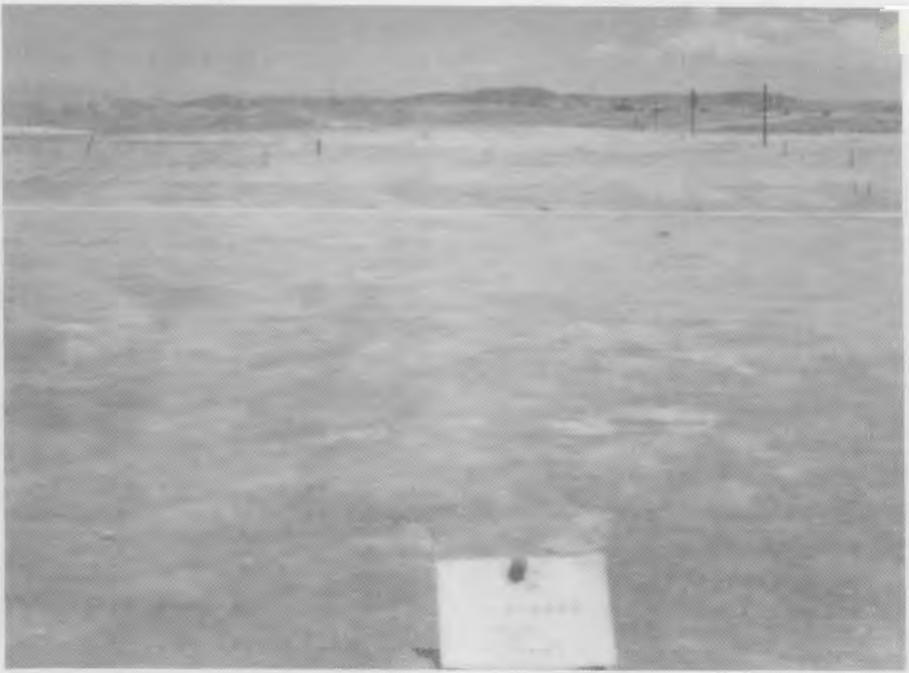

JUNE 1983 (OVERVIEW)

FIGURE A.7. Test Plot Stabilized with Dust Gard 


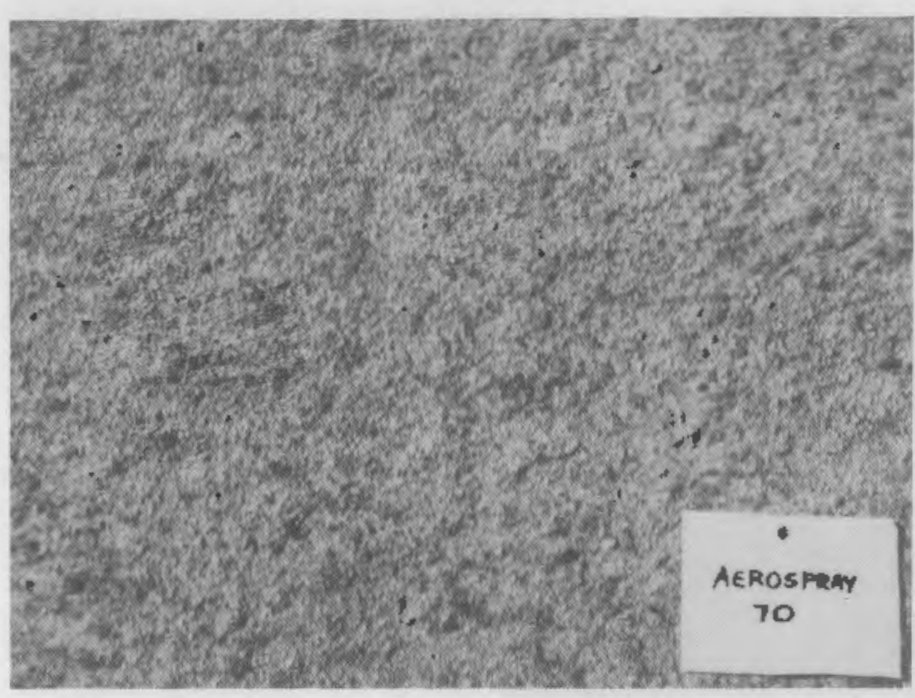

AUGUST $1982(0.5-\mathrm{m} \times 0.5-\mathrm{m}$ AREA)

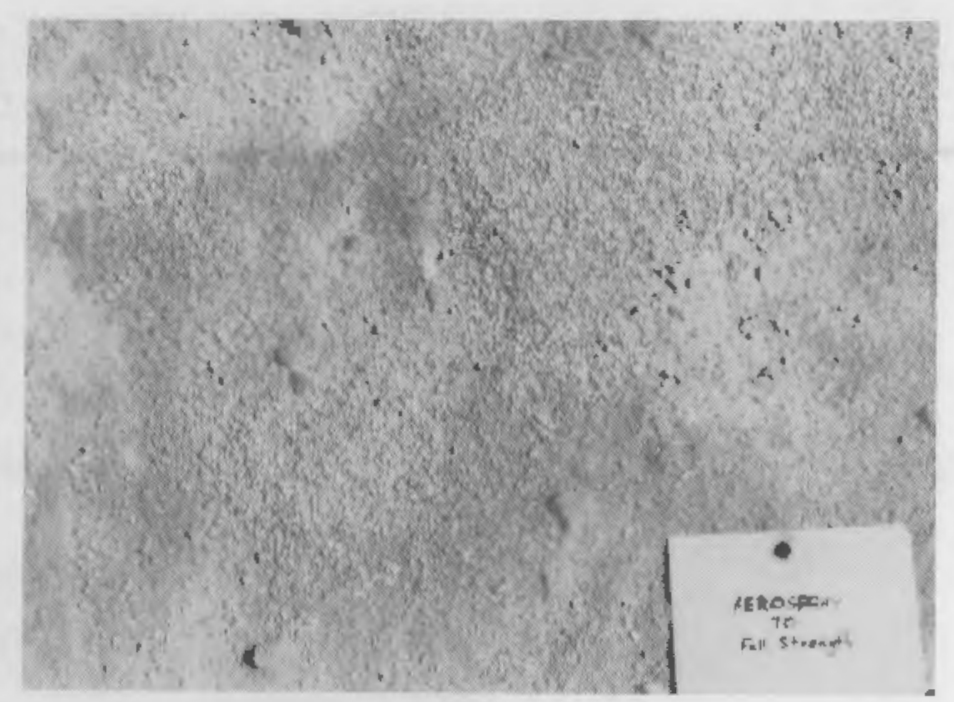

JUNE $1983(0.5-\mathrm{m} \times 0.5-\mathrm{m}$ AREA)

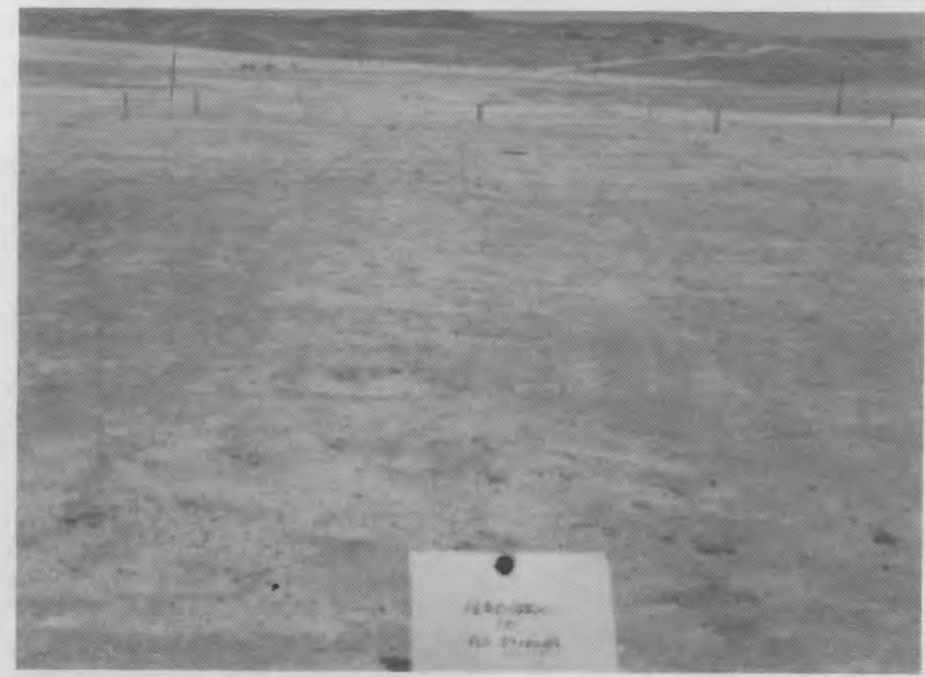

JUNE 1983 (OVERVIEW)

FIGURE A.8. Test Plot Stabilized with Aerospray-70 


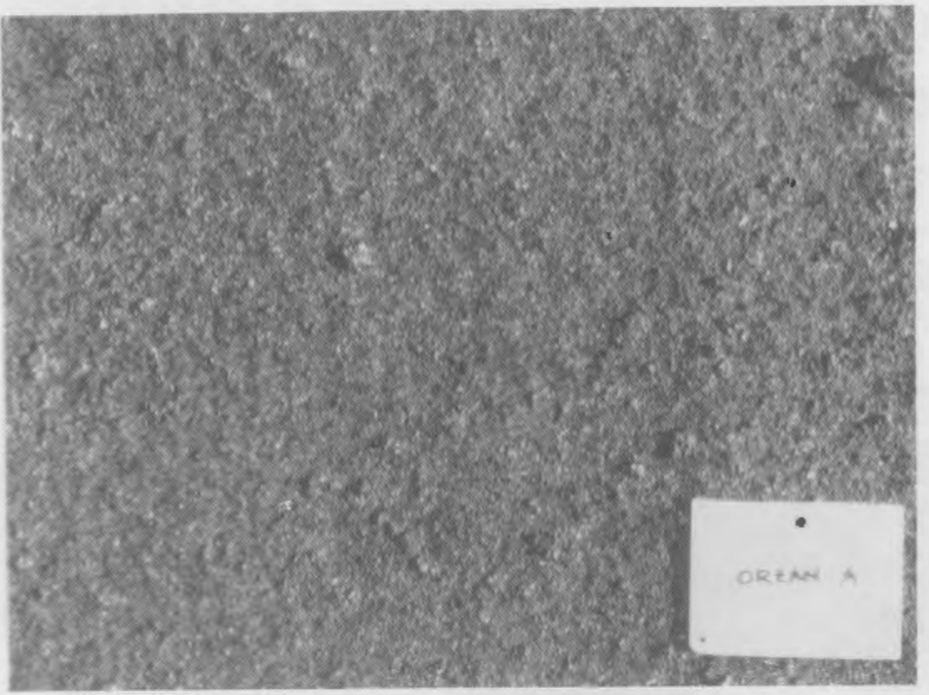

AUGUST $1982(0.5-\mathrm{m} \times$ 0.5-m AREA)

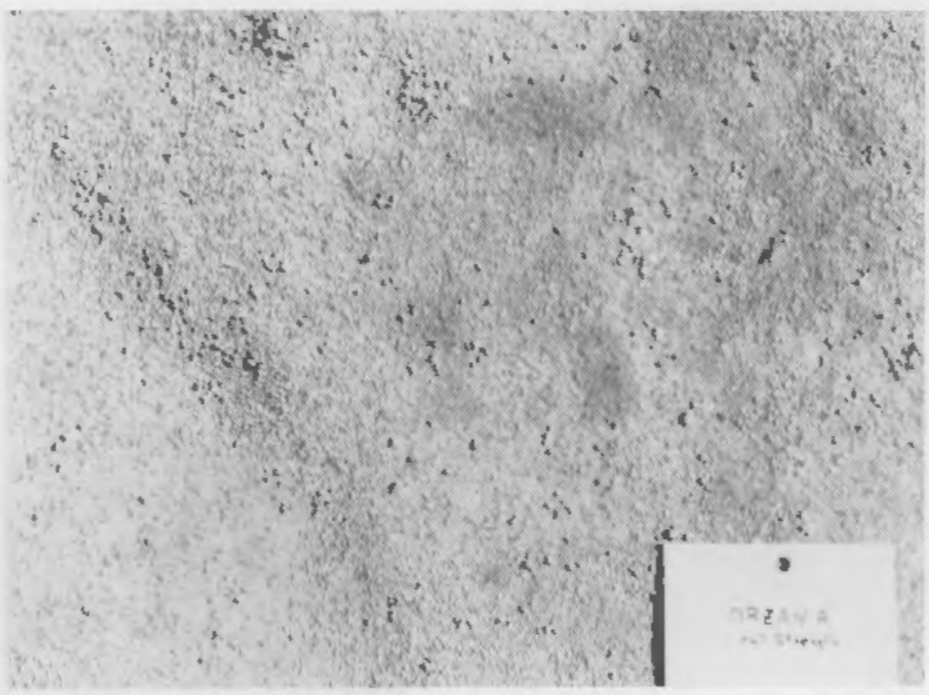

JUNE $1983(0.5-\mathrm{m} \times 0.5-\mathrm{m}$ AREA)

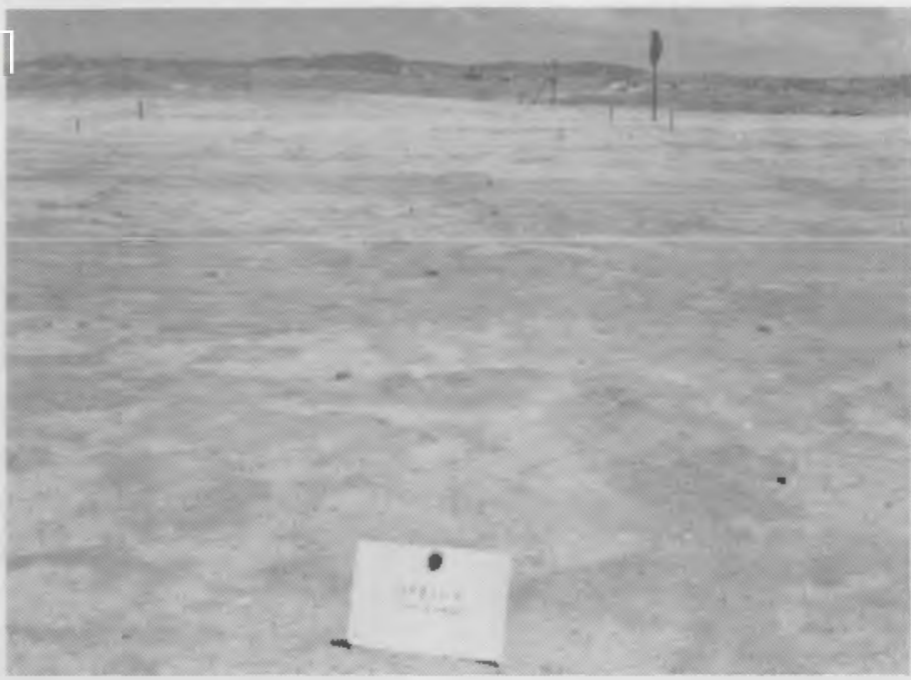

JUNE 1983 (OVERVIEW)

FIGURE A.9. Test Plot Stabilized with Orzan A 


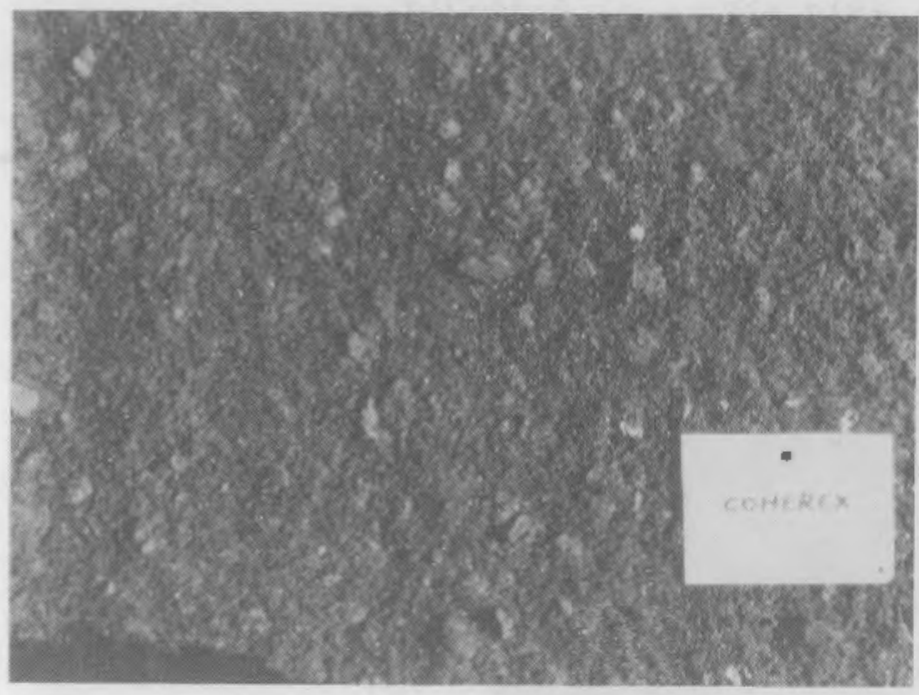

AUGUST $1982(0.5-\mathrm{m} \times 0.5-\mathrm{m}$ AREA $)$

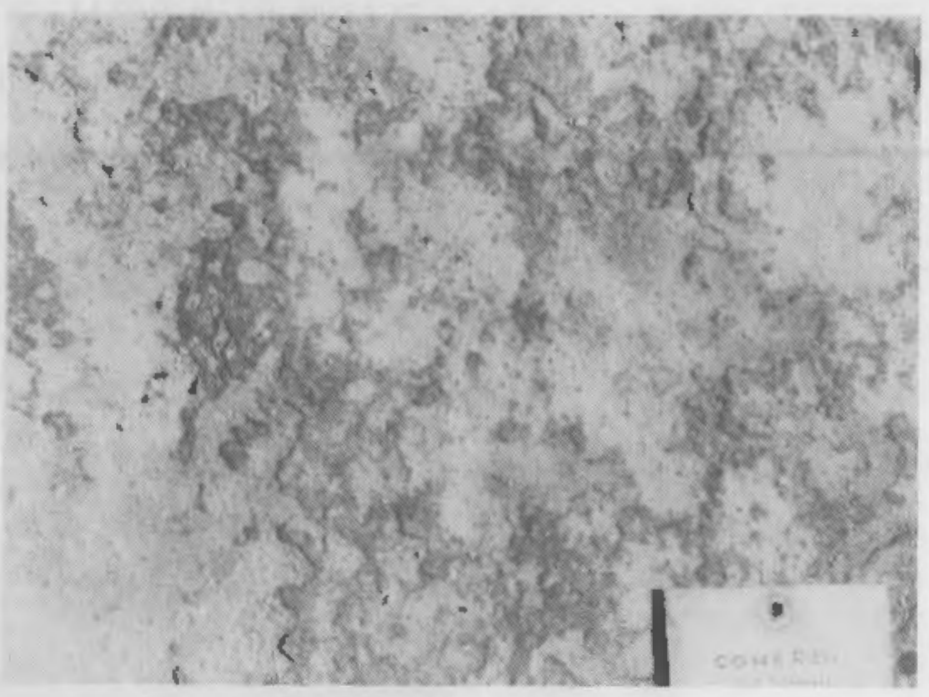

JUNE $1983(0.5-\mathrm{m} \times 0.5-\mathrm{m}$ AREA)

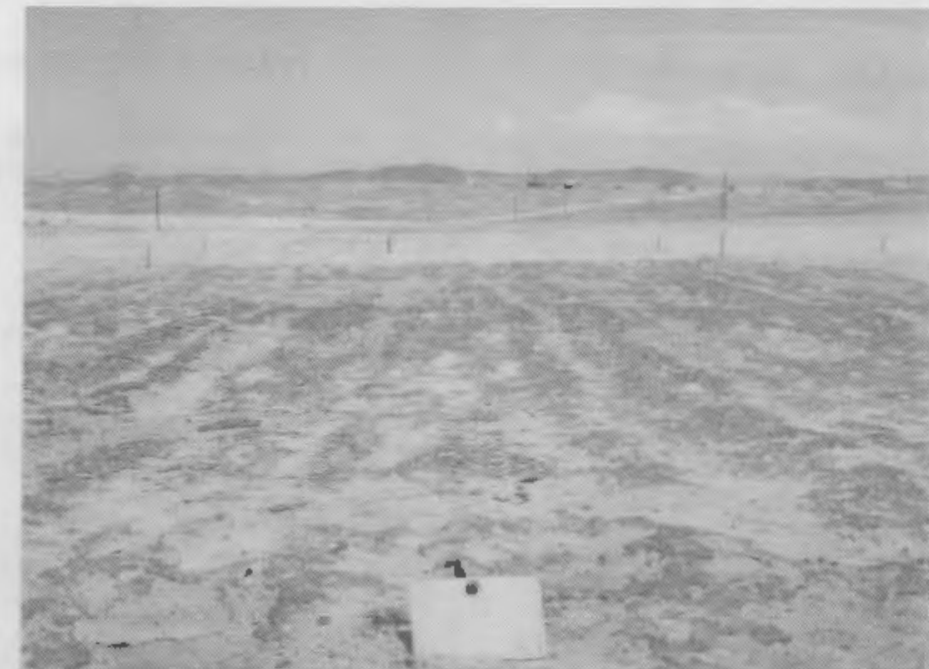

JUNE 1983 (OVERVIEW)

FIGURE A.10. Test Plot Stabilized with Coherex 


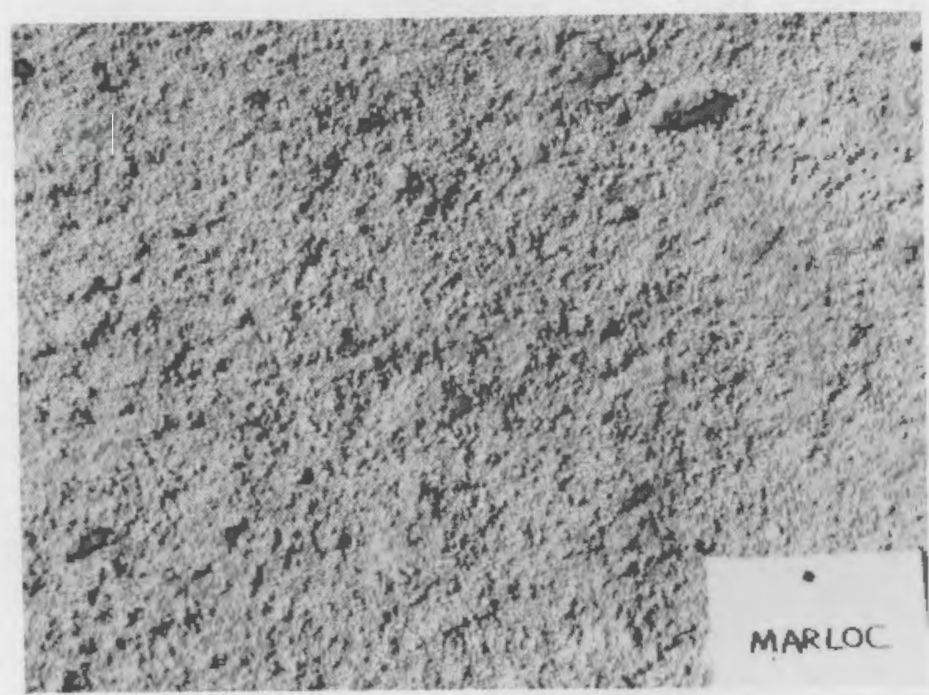

AUGUST $1982(0.5-\mathrm{m} \times 0.5-\mathrm{m}$ AREA)

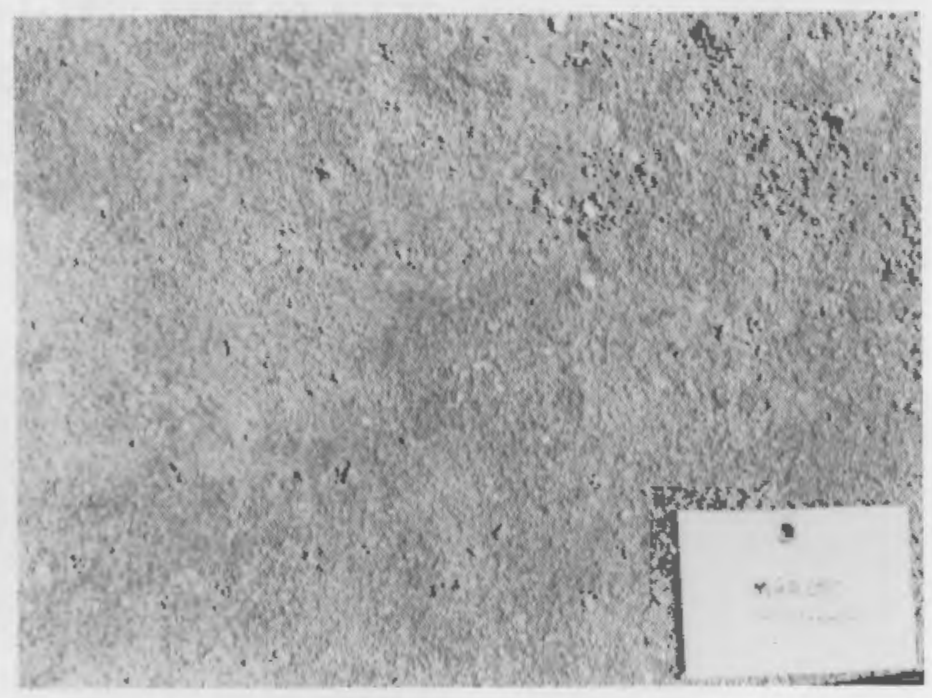

JUNE $1983(0.5-\mathrm{m} \times 0.5-\mathrm{m}$ AREA)

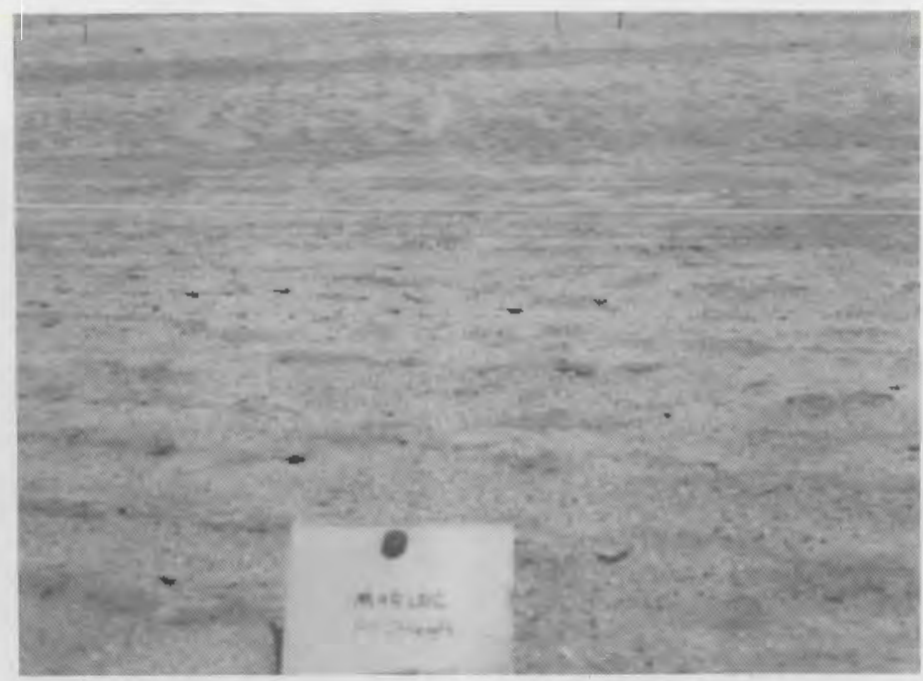

JUNE 1983 (OVERVIEW)

FIGURE A.11. Test Plot Stabilized with Marloc 


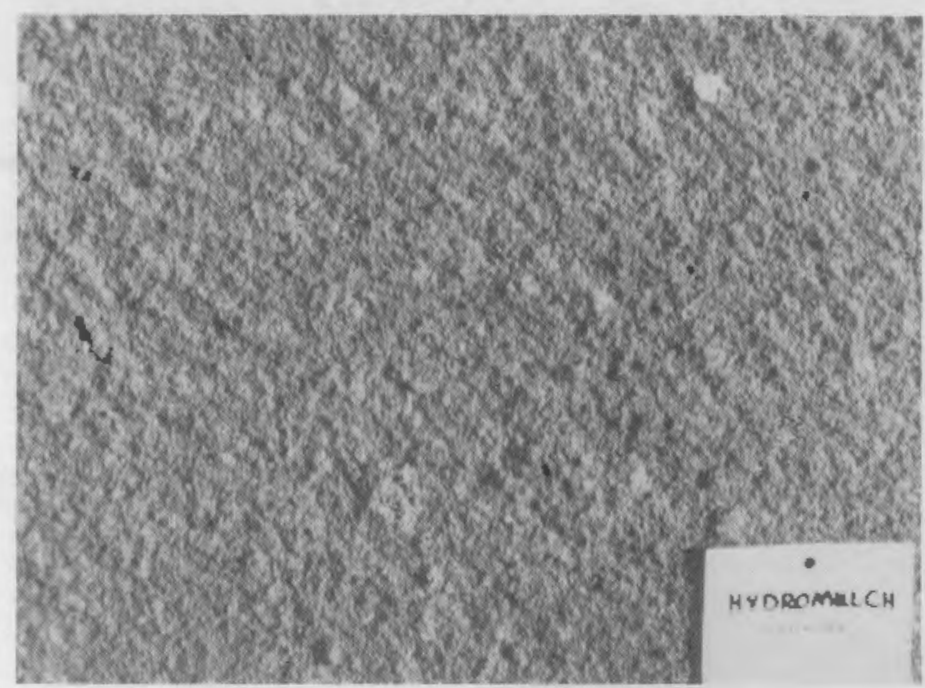

AUGUST $1982(0.5-\mathrm{m} \times 0.5-\mathrm{m}$ AREA)

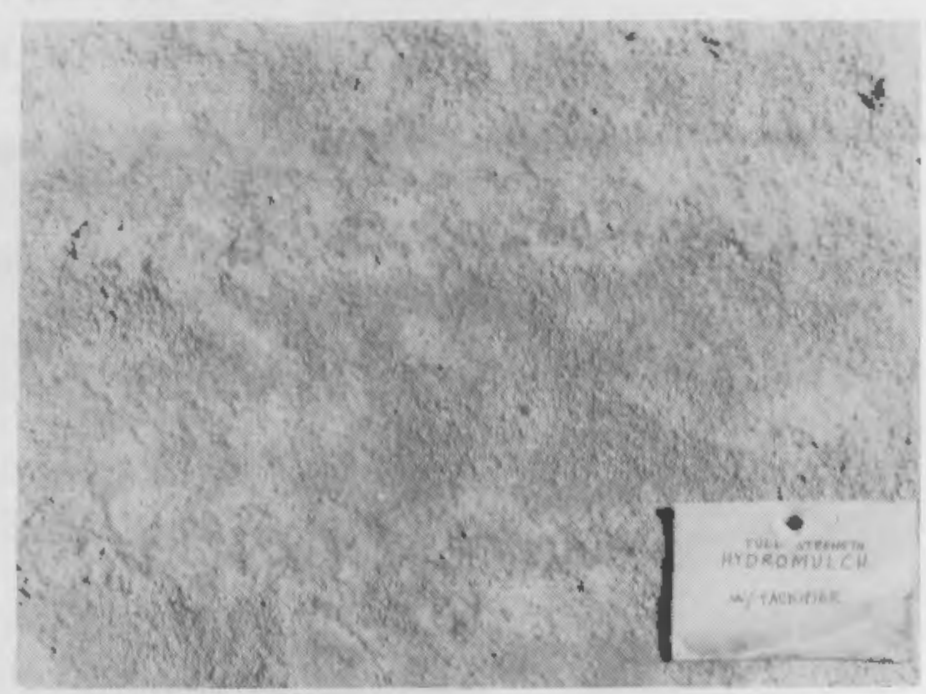

JUNE $1983(0.5-\mathrm{m} \times$ 0.5-m AREA)

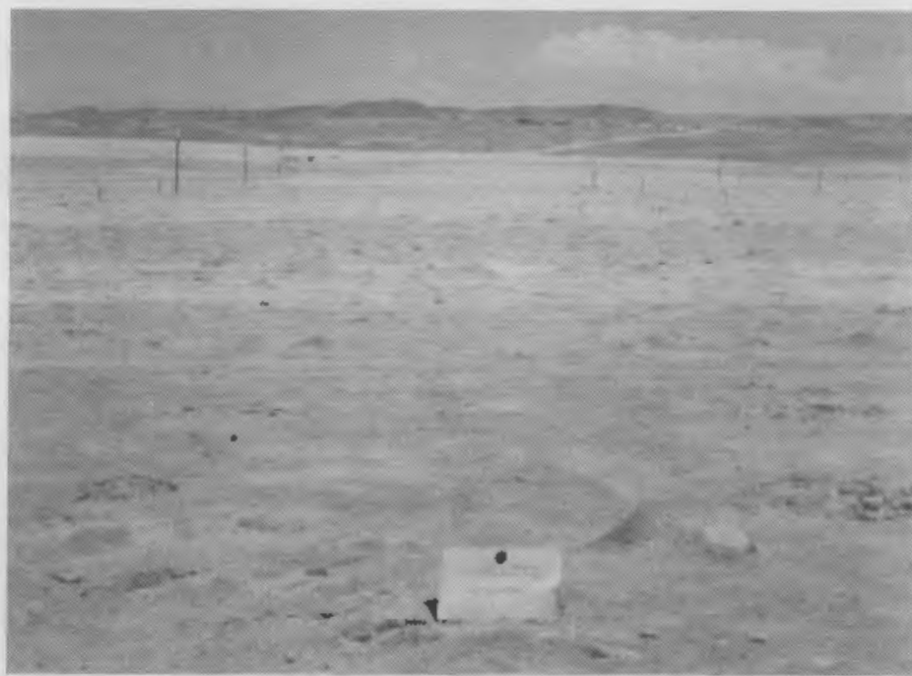

JUNE 1983 (OVERVIEW)

FIGURE A.12. Test Plot Stabilized with Hydro Mulch 


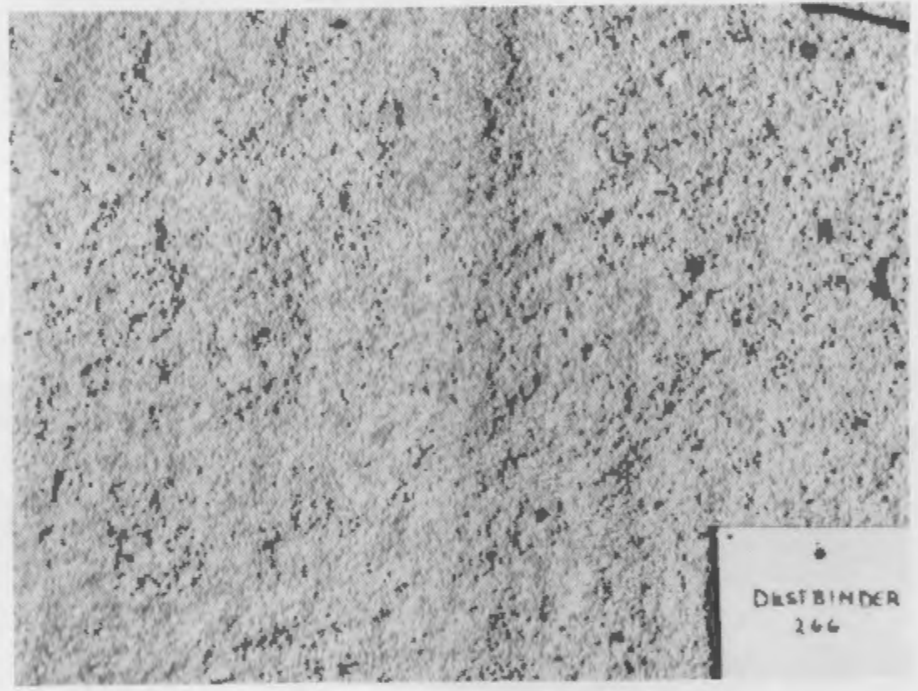

AUGUST $1982(0.5-\mathrm{m} \times 0.5-\mathrm{m}$ AREA)

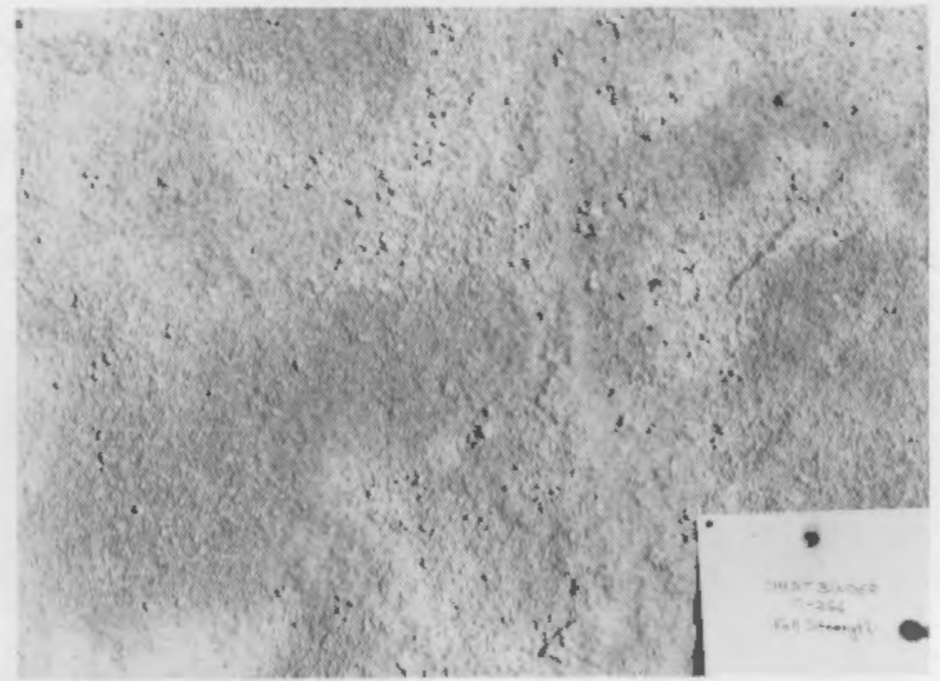

JUNE $1983(0.5-\mathrm{m} \times 0.5-\mathrm{m}$ AREA)

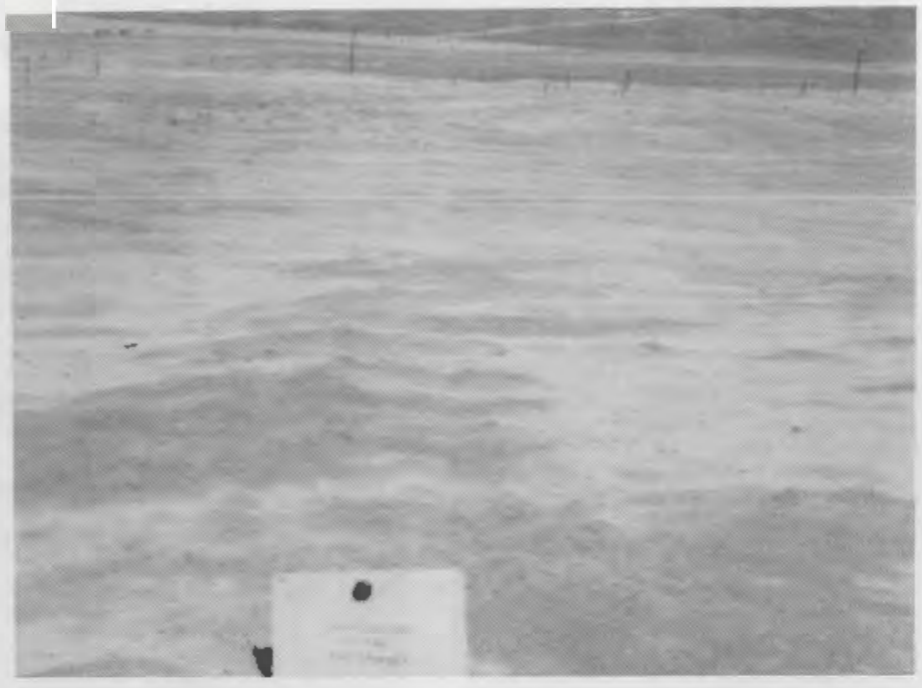

JUNE 1983 (OVERVIEW)

FIGURE A.13. Test Plot Stabilized with Dust Binder C-266 


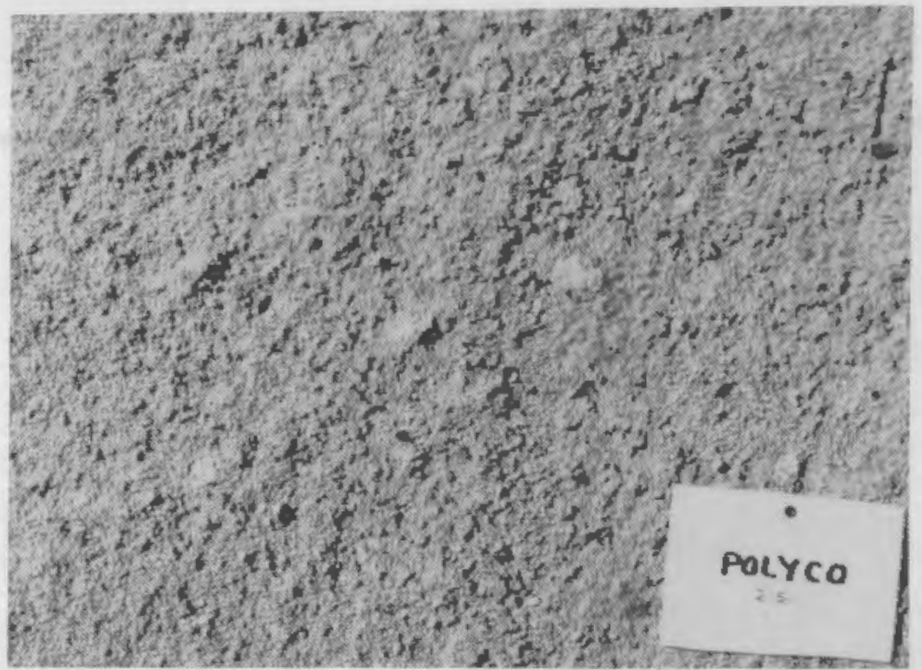

AUGUST $1982(0.5-\mathrm{m} \times 0.5-\mathrm{m}$ AREA)

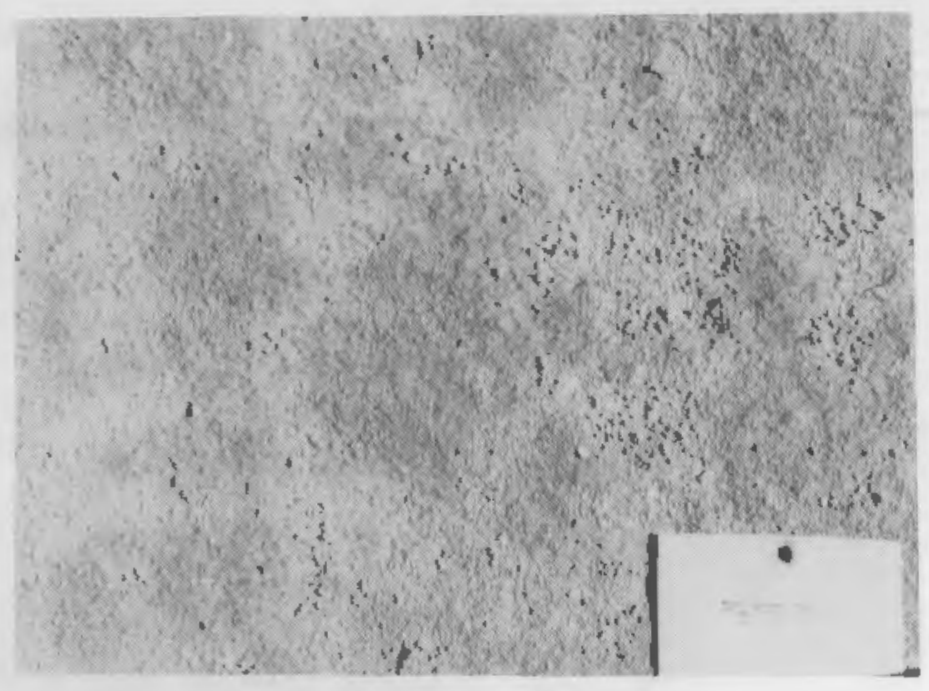

JUNE $1983(0.5-\mathrm{m} \times 0.5-\mathrm{m}$ AREA)

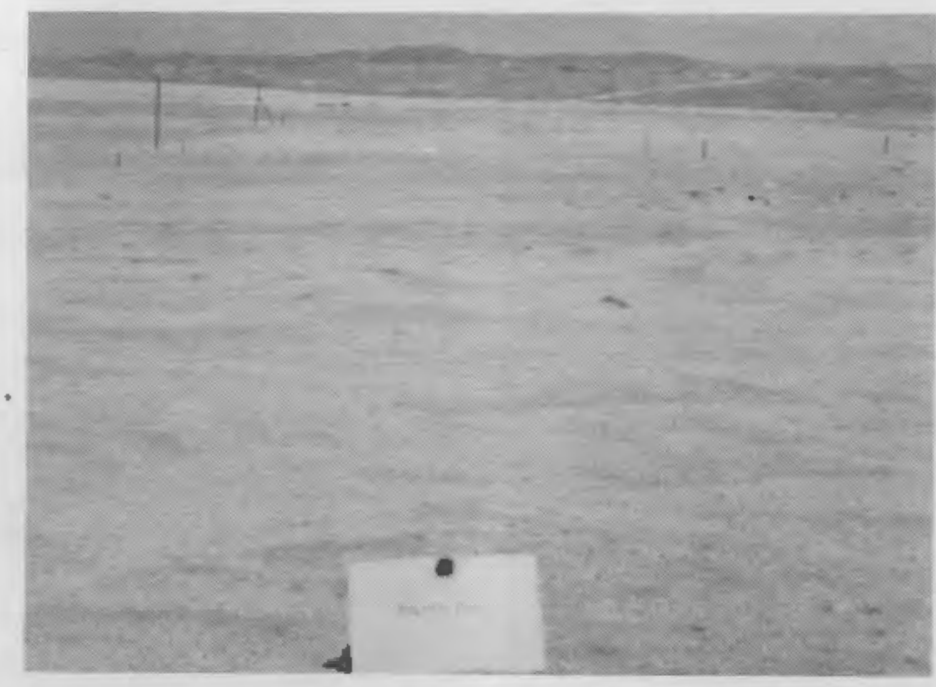

JUNE 1983 (OVERVIEW)

FIGURE A.14. Test Plot Stabilized with Polyco 2151 


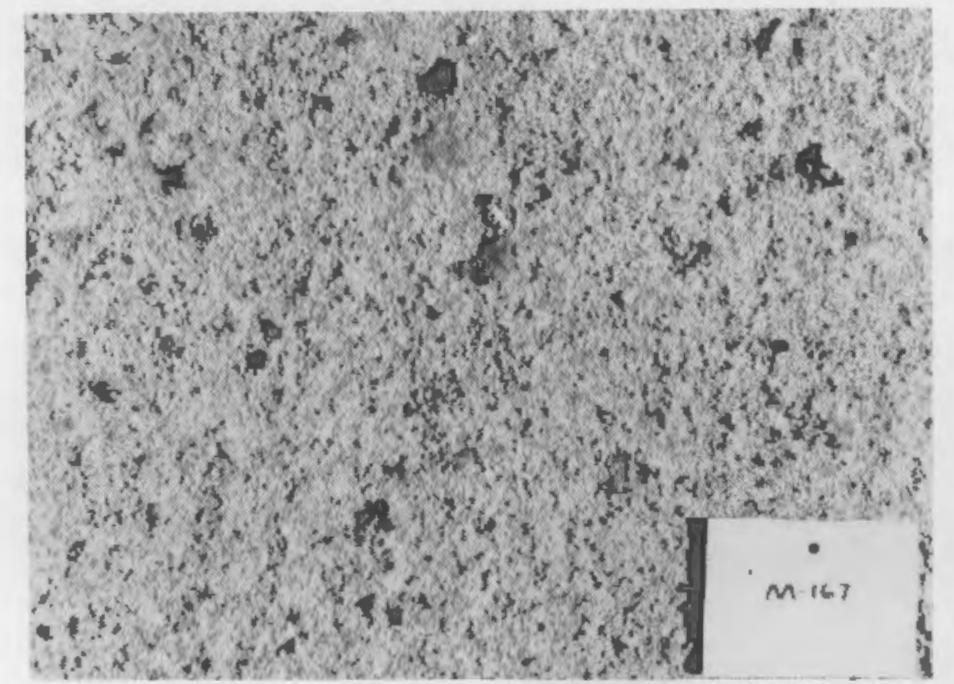

AUGUST $1982(0.5-\mathrm{m} \times 0.5-\mathrm{m}$ AREA)

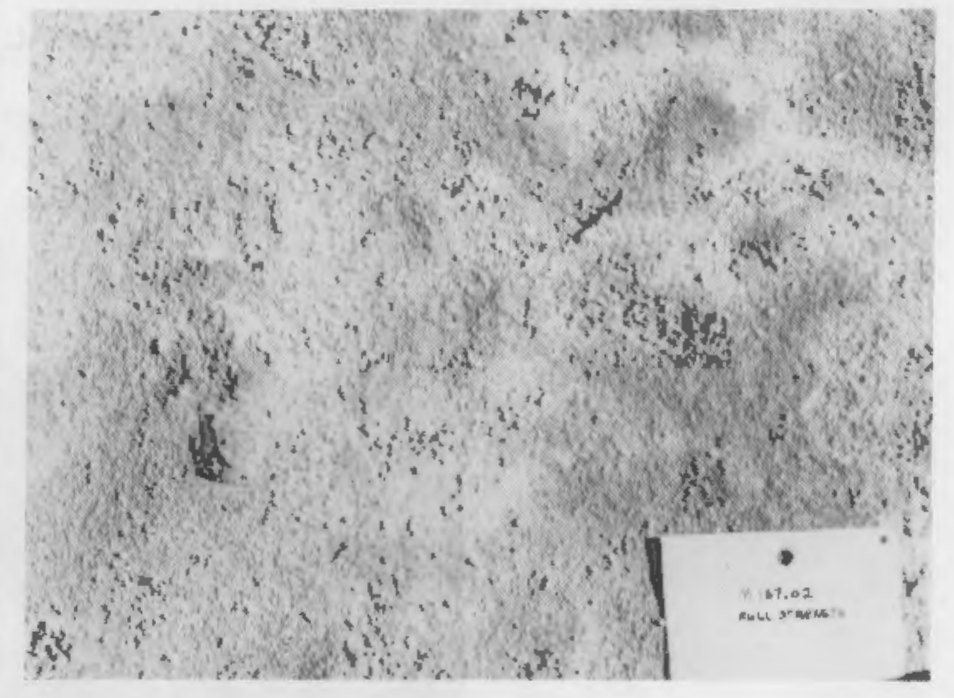

JUNE $1983(0.5-\mathrm{m} \times 0.5-\mathrm{m}$ AREA)

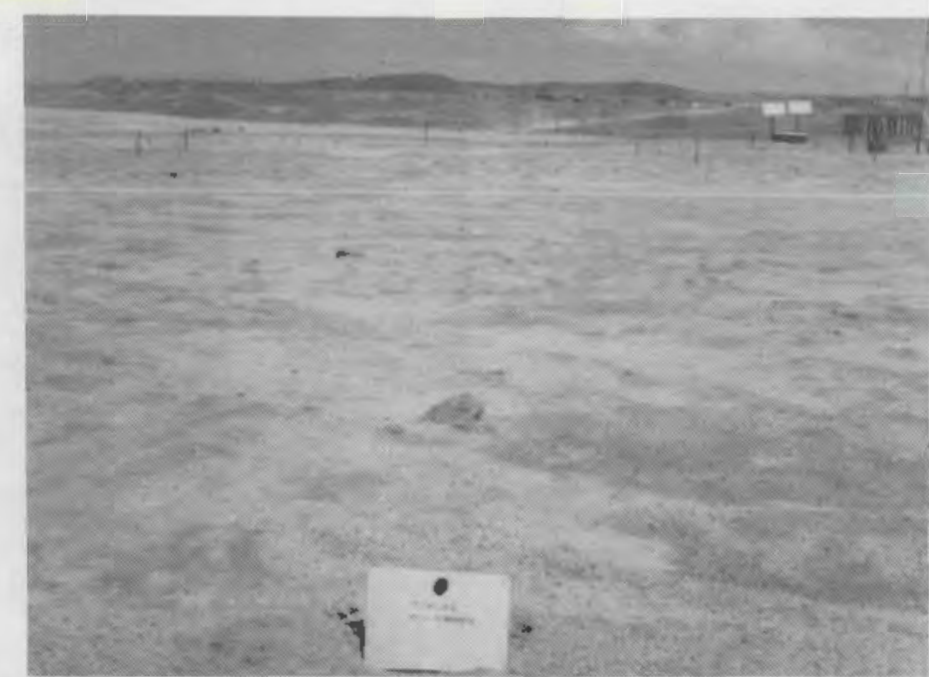

JUNE 1983 (OVERVIEW)

FIGURE A.15. Test Plot Stabilized with M-167 


\section{APPENDIX B}

FIELD TEST SITE WEATHER DATA 
TABLE B.1. Summary of Precipitation Data (in.) at FAP Field Test Site from $9 / 1 / 82$ Through $6 / 30 / 83$

1982

\begin{tabular}{|c|c|c|c|c|c|c|c|c|c|c|}
\hline Day & Sep & Oct & Nov & Dec & Jan & Feb & Mar & Apr & May & June \\
\hline 1 & 0.00 & 0.04 & 0.03 & 0.33 & 0.00 & 0.00 & 0.00 & 0.00 & 0.00 & 0.01 \\
\hline 2 & 0.00 & 0.00 & 0.00 & 0.07 & 0.00 & 0.02 & 0.00 & 0.00 & 0.00 & 0.06 \\
\hline 3 & 0.00 & 0.00 & 0.00 & 0.00 & 0.00 & 0.00 & 0.00 & 0.34 & 0.00 & 0.00 \\
\hline 4 & 0.00 & 0.00 & 0.00 & 0.00 & 0.00 & 0.00 & 0.09 & 0.01 & 0.00 & 0.10 \\
\hline 5 & 0.00 & 0.79 & 0.00 & 0.00 & 0.00 & 0.00 & 0.02 & 0.02 & 0.00 & 0.00 \\
\hline 6 & 0.00 & 0.00 & 0.00 & 0.00 & 0.00 & 0.00 & 0.02 & 0.00 & 0.02 & 0.00 \\
\hline 7 & 0.00 & 0.00 & 0.00 & 0.01 & 0.00 & 0.00 & 0.00 & 0.00 & 0.00 & 0.00 \\
\hline 8 & 0.00 & 0.27 & 0.00 & 0.00 & 0.01 & 0.00 & 0.00 & 0.03 & 0.02 & 0.00 \\
\hline 9 & 0.00 & 0.01 & 0.05 & 0.00 & 0.00 & 0.00 & 0.00 & 0.00 & 0.00 & 0.00 \\
\hline 10 & 0.00 & 0.00 & 0.00 & 0.00 & 0.00 & 0.05 & 0.00 & 0.00 & 0.08 & 0.00 \\
\hline 11 & 0.22 & 0.00 & 0.09 & 0.00 & 0.00 & 0.00 & 0.00 & 0.00 & 0.08 & 0.04 \\
\hline 12 & 0.00 & 0.00 & 0.00 & 0.00 & 0.00 & 0.00 & 0.00 & 0.07 & 0.05 & 0.06 \\
\hline 13 & 0.31 & 0.00 & 0.12 & 0.00 & 0.00 & 0.00 & 0.00 & 0.00 & 0.00 & 0.66 \\
\hline 14 & 0.37 & 0.00 & 0.00 & 0.05 & 0.00 & 0.13 & 0.05 & 0.00 & 0.00 & 0.00 \\
\hline 15 & 0.00 & 0.00 & 0.00 & 0.00 & 0.00 & 0.00 & 0.08 & 0.00 & 0.00 & 0.04 \\
\hline 16 & 0.00 & 0.00 & 0.00 & 0.00 & 0.00 & 0.00 & 0.00 & 0.00 & 0.20 & 0.01 \\
\hline 17 & 0.00 & 0.00 & 0.00 & 0.00 & 0.00 & 0.00 & 0.00 & 0.00 & 0.05 & 0.00 \\
\hline 18 & 0.00 & 0.07 & 0.00 & 0.00 & 0.00 & 0.00 & 0.00 & 0.00 & 0.00 & 0.00 \\
\hline 19 & 0.00 & 0.01 & 0.03 & 0.00 & 0.00 & 0.05 & 0.00 & 0.00 & 0.21 & 0.00 \\
\hline 20 & 0.00 & 0.00 & 0.00 & 0.00 & 0.00 & 0.00 & 0.00 & 0.00 & 0.00 & 0.00 \\
\hline 21 & 0.00 & 0.00 & 0.00 & 0.00 & 0.00 & 0.00 & 0.00 & 0.02 & 0.00 & 0.00 \\
\hline 22 & 0.00 & 0.00 & 0.00 & 0.00 & 0.00 & 0.00 & 0.00 & 0.00 & 0.00 & 0.00 \\
\hline 23 & 0.00 & 0.00 & 0.00 & 0.06 & 0.00 & 0.00 & 0.00 & 0.00 & 0.00 & 0.00 \\
\hline 24 & 0.00 & 0.00 & 0.00 & 0.17 & 0.00 & 0.00 & 0.00 & 0.00 & 0.00 & 0.00 \\
\hline 25 & 0.01 & 0.00 & 0.00 & 0.01 & 0.00 & 0.00 & 0.12 & 0.00 & 0.00 & 0.00 \\
\hline 26 & 0.38 & 0.00 & 0.00 & 0.00 & 0.00 & 0.00 & 0.00 & 0.02 & 0.00 & 0.24 \\
\hline 27 & 0.02 & 0.44 & 0.00 & 0.03 & 0.00 & 0.00 & 0.00 & 0.00 & 0.00 & 0.02 \\
\hline 28 & 0.08 & 0.00 & 0.00 & 0.00 & 0.27 & 0.00 & 0.00 & 0.00 & 0.00 & 0.02 \\
\hline 29 & 0.04 & 0.00 & 0.00 & 0.00 & 0.00 & 0.00 & 0.00 & 0.01 & 0.00 & 0.00 \\
\hline 30 & 0.78 & 0.00 & 0.00 & 0.00 & 0.00 & 0.00 & 0.00 & 0.26 & 0.22 & 0.00 \\
\hline 31 & 0.00 & 0.00 & 0.00 & 0.00 & 0.00 & 0.00 & 0.04 & 0.00 & 0.00 & 0.00 \\
\hline & 2.21 & 1.63 & 0.32 & 0.73 & 0.28 & 0.25 & 0.42 & 0.78 & 0.93 & 10.26 \\
\hline erage & 0.07 & 0.05 & 0.01 & 0.02 & 0.01 & 0.01 & 0.01 & 0.03 & 0.03 & 0.04 \\
\hline
\end{tabular}

1983 
TABLE B.2. Federal American Partners Wind Rose Data from $9 / 1 / 82$ to $9 / 30 / 82$

\begin{tabular}{|c|c|c|c|c|c|c|}
\hline \multirow{2}{*}{$\begin{array}{c}\text { Wind } \\
\text { Direction }\end{array}$} & \multicolumn{6}{|c|}{ Wind Speed, mph } \\
\hline & $0-7, \%$ & $8-11, \%$ & $12-18, \%$ & $19-24, \%$ & $724, \%$ & Tota!, \% \\
\hline$N$ & 1.39 & 0.69 & 0.00 & 0.00 & 0.00 & 2.08 \\
\hline NNE & 4.44 & 0.97 & 0.00 & 0.00 & 0.00 & 5.42 \\
\hline NE & 1.11 & 0.14 & 0.00 & 0.00 & 0.00 & 1.25 \\
\hline ENE & 2.08 & 1.81 & 1.94 & 0.97 & 0.28 & 7.08 \\
\hline$E$ & 0.42 & 0.69 & 0.83 & 0.97 & 0.83 & 3.75 \\
\hline ESE & 2.64 & 3.61 & 5.69 & 1.11 & 0.56 & 13.61 \\
\hline SE & 0.28 & 0.28 & 0.42 & 0.00 & 0.00 & 0.97 \\
\hline SSE & 2.22 & 1.25 & 0.42 & 0.00 & 0.00 & 3.89 \\
\hline S & 1.39 & 0.97 & 0.42 & 0.14 & 0.00 & 2.92 \\
\hline SSW & 4.58 & 5.56 & 10.83 & 1.67 & 0.00 & 22.64 \\
\hline SW & 1.11 & 0.83 & 3.89 & 0.14 & 0.00 & 5.97 \\
\hline WSW & 1.94 & 4.17 & 3.47 & 0.56 & 0.00 & 10.14 \\
\hline$W$ & 0.83 & 0.56 & 0.28 & 0.14 & 0.00 & 1.81 \\
\hline WNW & 3.89 & 2.50 & 1.39 & 0.14 & 0.00 & 7.92 \\
\hline NW & 0.28 & 0.97 & 0.83 & 0.00 & 0.00 & 2.08 \\
\hline NNW & 5.42 & 2.50 & 0.56 & 0.00 & 0.00 & 8.47 \\
\hline VAR. & 0.00 & 0.00 & 0.00 & 0.00 & 0.00 & 0.00 \\
\hline
\end{tabular}

TABLE B.3. Federal American Partners Wind Rose Data from $10 / 1 / 82$ to $10 / 31 / 82$

\begin{tabular}{|c|c|c|c|c|c|c|}
\hline irection & $0-7, \%$ & $8-11, \%$ & $12-18, \%$ & $19-24, \%$ & $324, \%$ & Total, \% \\
\hline N & 1.08 & 1.21 & 0.13 & 0.00 & 0.00 & 2.42 \\
\hline NNE & 1.88 & 2.28 & 0.54 & 0.00 & 0.00 & 4.70 \\
\hline NE & 0.27 & 0.27 & 0.00 & 0.00 & 0.00 & 0.54 \\
\hline ENE & 0.27 & 0.40 & 0.54 & 0.00 & 0.00 & 1.21 \\
\hline $\mathrm{E}$ & 0.00 & 0.00 & 0.00 & 0.00 & 0.00 & 0.00 \\
\hline ESE & 0.13 & 0.00 & 0.13 & 0.00 & 0.00 & 0.27 \\
\hline SE & 0.40 & 0.00 & 0.00 & 0.00 & 0.00 & 0.40 \\
\hline SSE & 0.40 & 0.13 & 0.00 & 0.00 & 0.00 & 0.54 \\
\hline S & 1.48 & 1.61 & 0.40 & 0.00 & 0.00 & 3.49 \\
\hline SSW & 5.91 & 6.85 & 13.71 & 6.05 & 0.27 & 32.80 \\
\hline SW & 0.81 & 3.76 & 6.45 & 2.96 & 0.27 & 14.25 \\
\hline WSW & 2.28 & 4.97 & 5.78 & 2.96 & 1.08 & 17.07 \\
\hline$W$ & 0.40 & 1.08 & 0.54 & 0.13 & 0.13 & 2.28 \\
\hline WNW & 3.36 & 1.08 & 1.21 & 0.00 & 0.00 & 5.65 \\
\hline NW & 0.94 & 0.81 & 0.54 & 0.00 & 0.00 & 2.28 \\
\hline NNW & 3.49 & 3.76 & 2.69 & 1.75 & 0.40 & 12.10 \\
\hline VAR. & 0.00 & 0.00 & 0.00 & 0.00 & 0.00 & 0.00 \\
\hline
\end{tabular}


TABLE B.4. Federal American Partners Wind Rose Data from $11 / 1 / 82$ to $11 / 30 / 82$

\begin{tabular}{|c|c|c|c|c|c|c|}
\hline \multirow{2}{*}{$\begin{array}{l}\text { Wind } \\
\text { Direction }\end{array}$} & \multicolumn{6}{|c|}{ Wind Speed, mph } \\
\hline & $0-7, \%$ & $8-11, \%$ & $12-18, \%$ & $19-24, \%$ & $>24, \%$ & Total, \% \\
\hline N & 0.42 & 0.28 & 0.28 & 0.00 & 0.00 & 0.97 \\
\hline NNE & 1.39 & 2.64 & 1.11 & 0.00 & 0.00 & 5.14 \\
\hline NE & 0.69 & 0.00 & 0.00 & 0.00 & 0.00 & 0.69 \\
\hline ENE & 0.28 & 0.14 & 0.00 & 0.00 & 0.00 & 0.42 \\
\hline$E$ & 0.14 & 0.00 & 0.00 & 0.00 & 0.00 & 0.14 \\
\hline ESE & 0.83 & 0.00 & 0.00 & 0.00 & 0.00 & 0.83 \\
\hline SE & 0.00 & 0.00 & 0.00 & 0.00 & 0.00 & 0.00 \\
\hline SSE & 1.53 & 0.42 & 0.97 & 0.69 & 0.00 & 3.61 \\
\hline S & 0.83 & 0.00 & 0.00 & 0.28 & 0.14 & 1.25 \\
\hline SSW & 5.14 & 5.00 & 16.25 & 14.72 & 4.44 & 45.56 \\
\hline SW & 1.25 & 1.39 & 6.11 & 5.56 & 2.08 & 16.39 \\
\hline WSW & 1.67 & 3.47 & 3.47 & 3.61 & 1.67 & 13.89 \\
\hline W & 0.28 & 0.56 & 0.42 & 0.00 & 0.00 & 1.25 \\
\hline WNW & 2.36 & 0.69 & 0.28 & 0.00 & 0.00 & 3.33 \\
\hline $\mathrm{NW}$ & 0.28 & 0.28 & 0.28 & 0.14 & 0.00 & 0.97 \\
\hline NNW & 2.50 & 2.36 & 0.42 & 0.28 & 0.00 & 5.56 \\
\hline VAR. & 0.00 & 0.00 & 0.00 & 0.00 & 0.00 & 0.00 \\
\hline
\end{tabular}

TABLE B.5. Federal American Partners Wind Rose Data from $12 / 1 / 82$ to $12 / 31 / 82$

\begin{tabular}{|c|c|c|c|c|c|c|}
\hline \multirow{2}{*}{$\begin{array}{l}\text { Wind } \\
\text { irection }\end{array}$} & \multicolumn{6}{|c|}{ Wind Speed, mph } \\
\hline & $0-7, \%$ & $8-11, \%$ & $12-18, \%$ & $19-24, \%$ & $324, \%$ & Total, \% \\
\hline N & 0.27 & 0.13 & 0.27 & 0.00 & 0.00 & 0.67 \\
\hline NNE & 0.54 & 0.54 & 2.55 & 1.08 & 0.00 & 4.70 \\
\hline NE & 0.40 & 0.00 & 0.00 & 0.00 & 0.00 & 0.40 \\
\hline ENE & 0.54 & 0.67 & 1.21 & 0.00 & 0.00 & 2.42 \\
\hline E & 0.00 & 0.13 & 0.13 & 0.13 & 0.40 & 0.81 \\
\hline ESE & 0.40 & 0.27 & 0.94 & 0.27 & 0.54 & 2.42 \\
\hline SE & 0.00 & 0.13 & 0.00 & 0.00 & 0.00 & 0.13 \\
\hline SSE & 0.54 & 0.27 & 0.00 & 0.27 & 0.27 & 1.34 \\
\hline S & 0.27 & 0.54 & 0.27 & 0.00 & 0.00 & 1.08 \\
\hline SSW & 3.23 & 4.44 & 7.93 & 21.51 & 16.40 & 53.49 \\
\hline SH & 0.40 & 0.81 & 3.63 & 2.69 & 5.38 & 12.90 \\
\hline WSW & 1.21 & 2.15 & 2.96 & 2.96 & 2.55 & 11.83 \\
\hline$W$ & 0.00 & 0.27 & 0.54 & 0.00 & 0.00 & 0.81 \\
\hline WNW & 0.54 & 0.27 & 0.81 & 0.40 & 0.00 & 2.02 \\
\hline NW & 0.27 & 0.00 & 0.94 & 0.40 & 0.00 & 1.61 \\
\hline NNW & 1.21 & 0.13 & 1.21 & 0.67 & 0.13 & 3.36 \\
\hline VAR. & 0.00 & 0.00 & 0.00 & 0.00 & 0.00 & 0.00 \\
\hline
\end{tabular}


TABLE B.6. Federal American Partners Wind Rose Data from $1 / 1 / 83$ to $1 / 31 / 83$

\begin{tabular}{|c|c|c|c|c|c|c|}
\hline \multirow{2}{*}{$\begin{array}{c}\text { Wind } \\
\text { Direction }\end{array}$} & \multicolumn{6}{|c|}{ Wind Speed, mph } \\
\hline & $0-7, \%$ & $8-11, \%$ & $12-18, \%$ & $19-24, \%$ & $224, \%$ & Total, \% \\
\hline$N$ & 0.13 & 0.00 & 0.00 & 0.00 & 0.00 & 0.13 \\
\hline NNE & 0.54 & 0.54 & 0.13 & 0.00 & 0.00 & 1.21 \\
\hline NE & 0.27 & 0.00 & 0.00 & 0.00 & 0.00 & 0.27 \\
\hline ENE & 0.13 & 0.00 & 0.00 & 0.00 & 0.00 & 0.13 \\
\hline$E$ & 0.13 & 0.00 & 0.00 & 0.00 & 0.00 & 0.13 \\
\hline ESE & 0.27 & 0.13 & 0.00 & 0.00 & 0.00 & 0.40 \\
\hline SE & 0.00 & 0.00 & 0.00 & 0.00 & 0.00 & 0.00 \\
\hline SSE & 0.94 & 1.34 & 0.27 & 0.00 & 0.00 & 2.55 \\
\hline S & 1.08 & 1.48 & 0.00 & 0.00 & 0.00 & 2.55 \\
\hline SSW & 5.65 & 6.72 & 15.99 & 15.99 & 9.01 & 53.36 \\
\hline SW & 0.81 & 1.21 & 4.30 & 5.24 & 4.30 & 15.86 \\
\hline WSW & 2.02 & 3.23 & 4.70 & 1.88 & 3.49 & 15.32 \\
\hline$W$ & 0.40 & 0.27 & 0.40 & 0.00 & 0.00 & 1.08 \\
\hline WNW & 1.34 & 0.13 & 1.08 & 1.34 & 0.13 & 4.03 \\
\hline NW & 0.13 & 0.00 & 0.40 & 0.13 & 0.13 & 0.81 \\
\hline NNW & 0.67 & 0.40 & 0.81 & 0.27 & 0.00 & 2.15 \\
\hline VAR. & 0.00 & 0.00 & 0.00 & 0.00 & 0.00 & 0.00 \\
\hline
\end{tabular}

TABLE B.7. Federal American Partners Wind Rose Data from $2 / 1 / 83$ to $2 / 28 / 83$

\begin{tabular}{|c|c|c|c|c|c|c|}
\hline \multirow{2}{*}{$\begin{array}{l}\text { Wind } \\
\text { Direction }\end{array}$} & \multicolumn{6}{|c|}{ Wind Speed, mph } \\
\hline & $0-7, \%$ & $8-11, \%$ & $12-18, \%$ & $19-24, \%$ & $>24, \%$ & Total, \% \\
\hline$N$ & 0.15 & D. 15 & 0.30 & 0.00 & .00 & 0.60 \\
\hline NNE & 1.34 & 1.19 & 0.09 & 0.00 & 0.00 & 3.42 \\
\hline NE & 0.15 & 0.00 & 0.00 & 0.00 & 0.00 & 0.15 \\
\hline ENE & 0.30 & 0.15 & 0.15 & 0.15 & 0.00 & 0.74 \\
\hline $\mathrm{E}$ & 0.00 & 0.00 & 0.00 & 0.00 & 0.00 & 0.00 \\
\hline ESE & 0.30 & 0.00 & 0.15 & 0.00 & 0.00 & 0.45 \\
\hline SE & 0.15 & 0.00 & 0.00 & 0.00 & 0.00 & 0.15 \\
\hline SSE & 1.34 & 0.74 & 0.15 & 0.00 & 0.00 & 2.23 \\
\hline S & 0.15 & 0.74 & 0.30 & 0.00 & 0.15 & 1.34 \\
\hline SSW & 3.27 & 6.99 & 22.32 & 28.13 & 11.31 & 72.02 \\
\hline SW & 0.45 & 0.30 & 1.64 & 1.93 & 1.04 & 5.36 \\
\hline WSW & 2.38 & 1.64 & 1.79 & 1.93 & 0.74 & 8.48 \\
\hline$W$ & 0.45 & 0.15 & 0.15 & 0.00 & 0.15 & 0.89 \\
\hline WNW & 1.34 & 0.30 & 0.15 & 0.15 & 0.00 & 1.93 \\
\hline NW & 0.15 & 0.00 & 0.00 & 0.00 & 0.00 & 0.15 \\
\hline NNW & 1.64 & 0.30 & 0.15 & 0.00 & 0.00 & 2.08 \\
\hline VAR. & 0.00 & 0.00 & 0.00 & 0.00 & 0.00 & 0.00 \\
\hline
\end{tabular}


TABLE B.8. Federal American Partners Wind Rose Data from $3 / 1 / 83$ to $3 / 31 / 83$

\begin{tabular}{|c|c|c|c|c|c|c|}
\hline \multirow{2}{*}{$\begin{array}{l}\text { Wind } \\
\text { Direction }\end{array}$} & \multicolumn{6}{|c|}{ Wind Speed, mph } \\
\hline & $0-7, \%$ & $8-11, \%$ & $12-18, \%$ & $19-24, \%$ & $>24, \%$ & Total, \% \\
\hline $\mathrm{N}$ & 0.54 & 1.08 & 0.00 & 0.13 & 0.00 & 1.75 \\
\hline NNE & 2.28 & 3.90 & 1.48 & 0.40 & 0.00 & 8.06 \\
\hline NE & 0.27 & 0.13 & 0.13 & 0.00 & 0.00 & 0.54 \\
\hline ENE & 1.08 & 1.48 & 2.69 & 0.54 & 0.00 & 5.78 \\
\hline E & 0.54 & 0.27 & 2.69 & 0.13 & 0.00 & 3.63 \\
\hline ESE & 1.48 & 1.08 & 2.15 & 1.21 & 0.00 & 5.91 \\
\hline SE & 0.54 & 0.40 & 0.00 & 0.00 & 0.00 & 0.94 \\
\hline SSE & 2.15 & 1.21 & 0.54 & 0.00 & 0.00 & 3.90 \\
\hline S & 0.94 & 0.27 & 0.13 & 0.00 & 0.00 & 1.34 \\
\hline SSW & 3.23 & 9.27 & 20.70 & 6.72 & 1.75 & 41.67 \\
\hline SW & 0.67 & 0.81 & 1.75 & 1.08 & 0.67 & 4.97 \\
\hline WSW & 1.88 & 2.82 & 2.55 & 2.15 & 1.34 & 10.75 \\
\hline$W$ & 0.13 & 0.13 & 0.13 & 0.00 & 0.00 & 0.40 \\
\hline WNW & 1.48 & 1.48 & 0.67 & 0.13 & 0.00 & 3.76 \\
\hline NW & 0.81 & 0.27 & 0.40 & 0.00 & 0.00 & 1.48 \\
\hline NNW & 2.02 & 2.15 & 0.81 & 0.13 & 0.00 & 5.11 \\
\hline VAR. & 0.00 & 0.00 & 0.00 & 0.00 & 0.00 & 0.00 \\
\hline
\end{tabular}

TABLE B.9. Federal American Partners Wind Rose Oata from $5 / 1 / 83$ to $5 / 31 / 83$

\begin{tabular}{|c|c|c|c|c|c|c|}
\hline \multirow{2}{*}{$\begin{array}{c}\text { Wind } \\
\text { oirection } \\
\end{array}$} & \multicolumn{6}{|c|}{ Wind Speed, mph } \\
\hline & $0-7, \%$ & $8-11, \%$ & $12-18, \%$ & $19-24, \%$ & $324, \%$ & Total, \% \\
\hline $\mathrm{N}$ & 1.21 & 1.88 & 0.54 & 0.00 & 0.00 & 3.63 \\
\hline NNE & 1.88 & 4.30 & 1.34 & 0.00 & 0.00 & 7.53 \\
\hline NE & 0.13 & 0.27 & 0.81 & 0.00 & 0.00 & 1.21 \\
\hline ENE & 2.15 & 2.15 & 6.45 & 1.48 & 0.13 & 12.37 \\
\hline E & 0.13 & 0.40 & 1.34 & 0.00 & 0.00 & 1.88 \\
\hline ESE & 0.94 & 2.15 & 2.28 & 0.00 & 0.00 & 5.38 \\
\hline SE & 0.40 & 0.13 & 0.27 & 0.00 & 0.00 & 0.81 \\
\hline SSE & 1.88 & 2.42 & 1.48 & 0.00 & 0.00 & 5.78 \\
\hline$S$ & 0.67 & 0.54 & 0.13 & 0.00 & 0.00 & 1.34 \\
\hline SSW & 3.09 & 9.01 & 6.85 & 0.00 & 0.00 & 18.95 \\
\hline SW & 0.67 & 0.81 & 0.81 & 0.27 & 0.00 & 2.55 \\
\hline WSW & 3.23 & 4.44 & 2.82 & 0.54 & 0.67 & 11.69 \\
\hline$W$ & 1.08 & 0.54 & 0.40 & 0.00 & 0.40 & 2.42 \\
\hline WNW & 4.44 & 5.11 & 3.23 & 0.40 & 0.00 & 13.17 \\
\hline NW & 1.21 & 0.67 & 1.21 & 0.13 & 0.00 & 3.23 \\
\hline NNW & 2.82 & 3.76 & 1.34 & 0.13 & 0.00 & 8.06 \\
\hline VAR. & 0.00 & 0.00 & 0.00 & 0.00 & 0.00 & 0.00 \\
\hline
\end{tabular}


TABLE B.10. Federal American Partners Wind Rose Data from $6 / 1 / 83$ to $6 / 30 / 83$

\begin{tabular}{|c|c|c|c|c|c|c|}
\hline \multirow{2}{*}{$\begin{array}{c}\text { Wind } \\
\text { Direction } \\
\end{array}$} & \multicolumn{6}{|c|}{ Wind Speed, mph } \\
\hline & $0-7, \%$ & $8-11, \%$ & $12-18, \%$ & $19-24, \%$ & $\geq 24, \%$ & Total, \% \\
\hline$N$ & 0.97 & 0.14 & 0.28 & 0.00 & 0.00 & 1.39 \\
\hline NNE & 3.06 & 0.69 & 0.14 & 0.00 & 0.00 & 3.89 \\
\hline NE & 0.42 & 0.28 & 0.00 & 0.00 & 0.00 & 0.69 \\
\hline ENE & 1.94 & 2.36 & 2.78 & 0.28 & 0.00 & 7.36 \\
\hline $\mathrm{E}$ & 0.14 & 0.42 & 0.97 & 0.28 & 0.00 & 1.81 \\
\hline ESE & 2.22 & 2.08 & 2.92 & 0.14 & 0.00 & 7.36 \\
\hline SE & 0.56 & 0.42 & 0.42 & 0.00 & 0.00 & 1.39 \\
\hline SSE & 3.47 & 2.92 & 1.11 & 0.42 & 0.00 & 7.92 \\
\hline S & 2.08 & 0.83 & 0.83 & 0.28 & 0.00 & 4.03 \\
\hline SSW & 3.75 & 7.08 & 12.22 & 1.67 & 0.00 & 24.72 \\
\hline SW & 0.56 & 1.25 & 1.94 & 0.00 & 0.14 & 3.89 \\
\hline WSW & 2.36 & 4.17 & 5.00 & 1.81 & 0.14 & 13.47 \\
\hline$W$ & 0.69 & 1.39 & 0.97 & 0.42 & 0.28 & 3.75 \\
\hline WNW & 2.22 & 3.89 & 4.17 & 0.28 & 0.00 & 10.56 \\
\hline NW & 0.83 & 0.42 & 0.56 & 0.14 & 0.00 & 1.94 \\
\hline NNW & 3.19 & 2.22 & 0.42 & 0.00 & 0.00 & 5.83 \\
\hline VAR. & 0.00 & 0.00 & 0.00 & 0.00 & 0.00 & 0.00 \\
\hline
\end{tabular}


No. of

Copies

OFFSITE

U.S. Nuclear Regulatory Commission

Division of Technical Information and Document Control

7920 Norfolk Avenue

Bethesda, MD 20014

E. F. Conti

Office of Nuclear Regulatory Research

U.S. Nuclear Regulatory Commission

Mail Stop 1130-SS

Washington, DC 20555

G. Gnugnoli

Office of Nuclear Material Safety and Safeguards

U.S. Nuclear Regulatory Commission

Mai1 Stop 1130-SS

Washington, DC 20555

F. Swanberg, Jr.

Office of Nuclear Regulatory Research

U.S. Nuclear Regulatory Commission

Mail Stop 1130-SS

Washington, DC 20555

K. Watts

American Nuclear CorporationGas Hill Project

Gas Hills Route

Riverton, WY 82501
DISTRIBUTION

No. of

Copies

0 . Lewis

Jacobs Engineering Group, Inc. 5301 Central Ave. NE

Suite 1700

Albuquerque, NM 87108

M. Matthews

Uranium Mill Tailings Remedial

Action Project

5301 Central Ave. NE

Suite 1700

A1buquerque, NM 87108

P. Rafferty

Weston

Weston Way

Westchester, PA 19380

ONSITE

50 Pacific Northwest Laboratory

T. J. Bander

P. A. Beedlow

T. D. Chikalla

S. K. Edler

M. R. Elmore (18)

M. G. Foley

G. W. Gee

J. N. Hartley (16)

G. B. Parker

P. C. Walkup

W. H. Walters

Publishing Coordination (2)

Technical Information (5) 


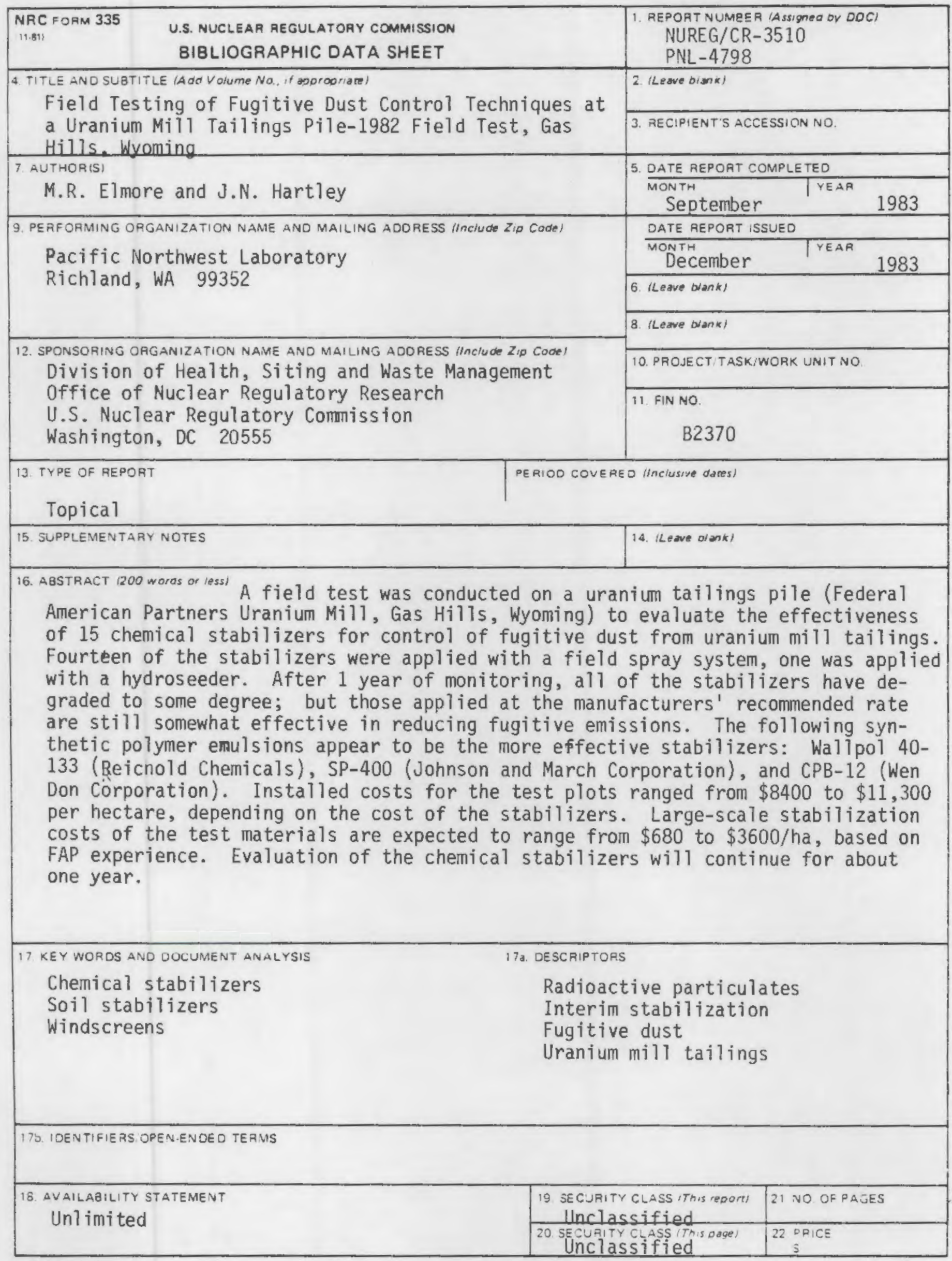


